\title{
CEO Turnover and Director Reputation ${ }^{\text {th }}$
}

Felix von Meyerinck, Jonas Romer*, and Markus Schmid

Swiss Institute of Banking and Finance, University of St.Gallen, CH-9000 St.Gallen, Switzerland

This version: Feb 28, 2021

\begin{abstract}
This paper analyzes the reputational effects of forced CEO turnovers on outside directors. Outside directors interlocked to a forced CEO turnover experience large and persistent increases in withheld votes at subsequent board re-elections relative to non-turnover-interlocked directors. Increases in withheld votes are confined to departures without a successor in place, performance-induced turnovers, turnovers that occur during CEOs' most productive tenure range, and turnovers at companies that share high common ownership with the interlocked firm. Reputational losses are larger for committee members responsible for hiring and monitoring the ousted CEO and directors affiliated with the CEO. Involvement in a forced CEO turnover is not associated with a long-term loss in directorships, but lost directorships are replaced by directorships at smaller firms. Our results imply that forced CEO turnovers signal a governance failure at the board level and that investors rely on salient actions to update their beliefs about directors' hidden qualities.
\end{abstract}

Keywords: CEO turnover, Director re-elections, Director reputation, CEO succession, Shareholder voting

JEL: G32, G34

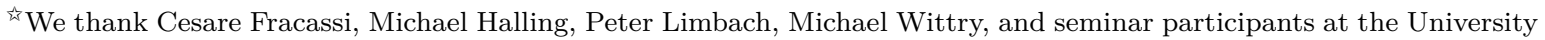
of St.Gallen and the University of Konstanz for helpful comments and suggestions. Part of the paper was written while Jonas Romer was visiting the University of Texas at Austin.

${ }^{*}$ Corresponding author.

Address: Swiss Institute of Banking and Finance, Unterer Graben 21, CH-9000 St.Gallen

Phone: +41712247035

Email address: jonas.romer@unisg.ch
} 


\section{Introduction}

Do directors gain or lose reputation from forcing out a CEO? There are two conflicting views on this question, which reflect conflicting views on the corporate governance signal transmitted by forced CEO turnovers. On the one hand, firing a poorly performing CEO may be a sign for effective monitoring by the board and thus indicate well-functioning corporate governance at the firm. This view represents the predominant position taken by the extant literature (e.g., Farrell \& Whidbee, 2000, Huson et al. 2001. Faleye, 2007, Jenter \& Kanaan, 2015, Kempf et al., 2017, Dasgupta et al., 2018). A forced CEO turnover is then expected to result in reputational benefits for involved directors. On the other hand, the need to fire the CEO, and thus disrupting a firm's management, may be perceived as a governance failure (Marcel et al. 2017). A better board may have appointed a better fitting CEO in the first place or may have replaced the CEO before negative performance consequences became observable. ${ }^{1}$ Consistent with this view, in the theoretical model of Dow (2013), directors choose not to fire a bad CEO because they do not want to reveal that they made a mistake in hiring her in the first place. Under this second scenario, directors involved in a forced CEO turnover are expected to experience a reputational loss. In this paper, we analyze the reputational effects of forced CEO turnovers on the directors responsible for monitoring and, if necessary, firing the CEO. Our analysis allows us to test whether forced CEO turnovers are indicative of good or bad corporate governance.

An analysis of the reputational effects of forced CEO turnovers on involved directors is empirically challenging. First, turnover decisions are endogenous and usually related to company performance et al. 2013). Second, widely used outcome variables at the director level, such as changes in the number of future board memberships, are subject to endogenous selection (Ertimur et al., 2012, Levit \& Malenko, 2016). Therefore, an ideal setting for measuring the reputational effect of forced CEO turnovers on directors needs to satisfy two conditions. First, it requires a setting that allows identifying the effect of a forced CEO turnover decision on director reputation. In an ideal experimental setting, forced CEO turnovers would be randomly assigned to some directors, but not others. The change in the reputation measure between directors who experience and those who do not experience a forced CEO turnover would then provide a causal estimate for forced turnovers' reputational effect. In this paper, we approximate such a randomized experimental setting by studying outside directors with at least two directorships who experience a forced CEO turnover at one of their firms (which we refer to as "turnover firm"). We then

\footnotetext{
${ }^{1}$ Anecdotal evidence consistent with the latter view is the forced CEO turnover of Ron Johnson at J.C. Penny, announced on April 8, 2013. Following the announcement, the board of J.C. Penny faced hefty criticism, including calls to resign entirely, because of poor handling and timing of the turnover. On April 9, 2013, Reuters reported that "Hours after the switch was announced on Monday, there was at least one call for the entire board to resign, while others suggested shareholders might vote out current directors at the company's next annual meeting. 'It was the wrong thing for the board to do to get rid of Johnson here. With the board firing Johnson now, at this stage in the game, they should tender their own resignation as well,' said Brian McGough, managing director and head of the retail group at research firm Hedgeye Risk Management."
} 
compare the change in the reputation measure from before the CEO turnover to after the CEO turnover at other firms on whose board these directors sit (the "interlocked firms") to changes in the reputation measure of directors that are not interlocked to a forced CEO turnover. Our setting's main advantage is that these interlocked firms, and the directors sitting on their boards, are unaffected by characteristics of the turnover firm, including factors that led to the forced CEO turnover. Thus, we can utilize CEO turnovers as exogenous shocks onto interlocked directors and use the directors not interlocked to a CEO turnover as control directors, and, hence, measure reputational effects net of other influences from the interlocked firm.

Second, a study of the reputational effects of forced CEO turnovers on involved directors requires a measure of reputation that cannot be directly influenced by the director herself. In this paper, our primary measure for the reputational effect is the percentage of withheld votes in director re-elections (defined as the sum of votes withheld and votes against, divided by the total number of votes cast). Unlike the change in the number of future directorships, the percentage of withheld votes is not subject to endogenous selection as the directors cannot directly influence it, but only by the shareholders. Using director vote outcomes as a measure of director reputation, we rely on a growing stream of literature that shows that investors actively use withheld votes to evaluate directors' actions and that directors respond to changes in withheld votes (e.g., Ertimur et al., 2012, Brochet \& Srinivasan, 2014 Aggarwal et al. 2019). For instance, Aggarwal et al. (2019) show that, even in uncontested director elections, increased withheld votes lead to higher director turnover, committee demotions, and reduced opportunities in the director labor market. Hence, withheld votes constitute a direct measure of shareholder satisfaction regarding individual directors that is not subject to endogenous selection by the directors.

To implement our identification strategy, we estimate generalized difference-in-differences regressions on a hand-collected sample of turnover-interlocked director re-elections and a control sample of non-turnoverinterlocked director re-elections. Specifically, we regress the change in the share of withheld votes in director re-elections on a treatment dummy indicating whether a director was involved in a forced CEO turnover at another firm after the last election and firm- and director-level control variables. We firstdifference our outcome and control variables on the director-firm level. This ensures that time-invariant director characteristics, such as talent and firm characteristics, such as industry, do not influence our difference-in-differences estimates. Moreover, we include industry-year fixed effects. These fixed effects control for time trends, industry-specific trends, and unobserved time-varying industry shocks in withheld votes and ensure that we compare vote results between turnover-interlocked and non-turnover-interlocked directors within the same industry and year. In further tests, we augment our main analysis with firm and director fixed effects. These fixed effects also remove time-invariant firm-specific and director-specific effects from the director re-elections and allow us to compare turnover-interlocked directors with other 
non-turnover-interlocked directors at the same firm as well as with the same director absent a CEO turnover.

Our results show that directors involved in a forced CEO turnover experience a significant increase in withheld votes at their next re-election at interlocked firms compared to directors not interlocked to a forced CEO turnover. Economically, the results are sizeable: In our baseline specification, turnoverinterlocked outside directors experience a 1.20 percentage point increase in withheld votes $(19.6 \%$ versus the sample mean) at their next board re-election date compared to non-interlocked directors in the same industry and year. Results from variations of our baseline specification, including different sets of control variables and fixed effects, remain largely unchanged, suggesting that controlling for various time-variant and time-invariant characteristics does not affect our findings. Hence, the shock of a forced CEO turnover on interlocked directors does not coincide systematically with other changes in director and firm characteristics, providing strong support for the conjecture that forced CEO turnovers represent an exogenous shock onto interlocked directors' vote outcomes.

We conduct the usual diagnostic checks on our difference-in-differences analysis. The identifying assumption central to a causal interpretation of difference-in-differences estimates is that treated and control samples follow parallel trends. Consistently, we show that there is no significant difference in the change in withheld votes between turnover-interlocked and non-turnover-interlocked directors before the treatment, confirming that the parallel trends assumption holds. We also show that the change in withheld votes coincides with the turnover event and does not revert subsequently, suggesting that the negative reputational effects persist.

When looking at the cross-sectional variation across different turnover types, we find that the adverse reputational effects are confined to CEO departures without a full succession in place, performance-induced forced turnovers and turnovers that occur during the most productive tenure range of a CEO. Additionally, our results show that the reputational effects mainly affect directors affiliated with the departing CEO and directors with a committee-based monitoring role towards the CEO. These results suggest that CEO turnovers in which involved directors failed to perform their duty to hire, monitor and fire CEOs in a timely and value-preserving manner are associated with stronger reputational losses, which corroborates the idea that $\mathrm{CEO}$ turnovers are often the result of a governance failure rather than the realization of a well-functioning governance system. We also provide evidence on the channels through which directors involved in forced CEO turnovers are penalized. Specifically, we show that the negative vote effect is concentrated on turnover events in which institutional investors hold above mean/median ownership stakes in both the turnover and the interlocked firms. Hence, well-informed institutional investors, who monitor both the turnover and interlocked firms, are responsible for penalizing the directors. Moreover, these results suggest that the recent growth in institutional holdings and the increasing concentration 
of ownership by a few very large asset managers might also have positive consequences, despite having raised anti-competition concerns (e.g., Azar et al., 2018). Namely, large ownership and substantial crossholdings facilitate directors' monitoring across multiple firms and thereby provide stronger incentives for directors to act in shareholders' best interests.

An alternative interpretation to the reputation-based explanation of our results is director distraction. Forced CEO turnovers may demand significant time and effort from directors involved in the turnover process. Turnover-interlocked directors may thus have less time for their board duties at interlocked firms (e.g., Masulis \& Zhang, 2019; Stein \& Zhao, 2019), resulting in a negative assessment of these directors by shareholders. To rule out this alternative explanation, we make use of sudden deaths of CEOs. Sudden CEO deaths represent shocks to the time demand of directors similar to forced CEO departures. However, sudden CEO deaths are outside of directors' control and thus not expected to affect the directors' reputation. Thus, if distraction drives our results, sudden CEO deaths are expected to trigger an increase in withheld votes at interlocked firms similar to that of forced CEO departures. Consistent with our reputation-based explanation but inconsistent with a distraction-based explanation, we find that CEO deaths do not affect directors' re-election results at interlocked firms.

In a second test of the distraction-based alternative explanation to our results, we look at other board members who share committee memberships with the turnover-interlocked directors. If a CEO turnover leads to the distraction of involved directors at interlocked firms, this distraction likely extends to other directors sitting on these boards. In particular, it may extend to members of the same committees within these boards, as these directors may have to take over a part of the interlocked director's committee responsibilities. Therefore, if distraction drives our results, committee-peers of turnover-interlocked directors would be expected to suffer a significant increase in withheld votes as well. Consistent with our reputation-based explanation, but inconsistent with a distraction-based explanation, we find that these directors do not experience a significant change in withheld votes around forced CEO turnovers of their committee-peers.

Another potential concern with our interpretation of the results is that both a forced CEO turnover and an increase in withheld votes may result from poor performance at the turnover firm. On the one hand, firms that experience poor performance are more likely to force out their CEO (e.g., Dasgupta et al. 2018: Fee et al. 2018). On the other hand, poor firm performance may be linked to bad monitoring and advice provided by the board of directors (e.g., Klein, 1998, Brick \& Chidambaran, 2010). Directors interlocked to poorly performing firms may thus be penalized for the poor performance, which resulted in the forced CEO turnover, rather than the forced CEO turnover itself. Alternatively, our results may capture a reverse causality effect, as directors facing a decline in vote support may feel pressure to signal strength to shareholders by ousting the CEO (Fos et al. 2018). To differentiate whether forced 
CEO turnovers or poor firm performance drive the observed reputational loss, and to test whether the CEO turnover is rather the result of deteriorating votes than the other way around, we conduct a propensity score matching analysis, in which we match CEO turnover firms to non-turnover firms with the same propensity of experiencing a forced CEO turnover, based on company performance, changes in board re-election votes outcomes and other firm, industry, CEO, and governance characteristics. Hence, treatment and control firms only differ in their decision to dismiss the CEO. We continue to find a significant increase in withheld votes of turnover-interlocked directors versus directors interlocked to matched firms without a forced CEO turnover but otherwise similar characteristics. This implies that the reputational losses for the involved directors result from the forced CEO turnovers and not from other factors such as deteriorating company performance or poor re-election vote outcomes pre-dating the forced CEO turnover that may eventually induce directors to force out the CEO.

In the final part of the paper, we follow prior research (Farrell \& Whidbee, 2000, Ellis et al., 2020) and study the effect of forced CEO turnovers on future directorships. We acknowledge that this analysis may be subject to endogeneity problems. Directors may choose to leave some board seats voluntarily, for instance, due to reputational concerns connected to the past performance of the turnover firm, increased busyness as a result of the CEO succession, or disagreements over the turnover (Farrell \& Whidbee, 2000 Ertimur et al., 2012, Levit \& Malenko, 2016, Fahlenbrach et al., 2017, Masulis \& Zhang, 2019. Ellis et al. 2020). Still, if involvement in a forced CEO turnover is associated with a reputational loss for outside directors, turnover-interlocked directors may lose outside directorships, or at least not gain further outside directorships. In addition to changes to the number of directorships held, the board seats that directors obtain may be at smaller firms. We track our sample directors and their board seats over the years following the CEO turnover to analyze this empirically. Results from these analyses show that outside directors involved in a forced CEO turnover on average do not lose board seats five years after the turnover, with initially lost directorships at the turnover firms offset by newly acquired board seats in the subsequent four years. However, we find that lost board seats of directors previously involved in a forced CEO turnover are replaced by new board seats at smaller firms. These results support the idea that directors suffer a reputational loss from involvement in a forced CEO turnover as board seats at smaller companies are known to be associated with smaller compensation packages (Ryan \& Wiggins, 2004), less power and prestige (Shivdasani, 1993, Adams \& Ferreira, 2008, Masulis \& Mobbs, 2014), and reduced networking benefits (Yermack, 2004, Fich, 2005).

Our paper contributes to two strands of research. First, our paper adds to the literature on director incentives and reputation. This literature rests on the assumption that directors are incentivized to signal their quality as monitors and advisors of management to shareholders to build a reputation in the market for corporate directors (e.g., Fama, 1980; Fama \& Jensen, 1983). Song \& Thakor (2006) model 
how career considerations of directors affect their actions. Similarly, Levit \& Malenko (2016)develop a model in which directors' reputational concerns affect both their actions and the structure of corporate boards. Specifically, the model in Levit \& Malenko (2016) suggests that shareholders struggle to assess a priori the intrinsic characteristics of a director. CEO turnovers represent one of the most critical and salient decisions that boards take (e.g., Fama \& Jensen, 1983). Therefore, CEO turnovers, and their surroundings, may serve shareholders as a posterior ability assessment of directors' quality, as in Levit \& Malenko (2016)'s model. Consistent with a well-functioning market for corporate directors that relies on the signaling of ability, our empirical results show that forced CEO turnovers result in a negative assessment of directors' quality by shareholders.

The existing empirical literature on the consequences of forced CEO turnovers for directors is limited. Farrell \& Whidbee (2000) are the first to study career consequences for involved directors following forced CEO turnovers. They find that outside directors have a higher likelihood of leaving the turnover firm following a CEO dismissal but that those directors who remain with the turnover firm have a higher likelihood of gaining additional board seats. Ellis et al. (2020) investigate the learning experience resulting from forced CEO turnovers. They document that turnover-experienced outside directors are more likely to fire CEOs of underperforming firms and hire outside CEOs after a turnover. When analyzing director labor market outcomes following the turnover, they find results that contradict those of Farrell \& Whidbee (2000): Directors involved in the CEO dismissal are not rewarded with additional board seats. Instead, the number of other board positions following a forced CEO turnover is reduced. Similarly, Marcel et al. (2017) show that following disruptive CEO successions with an interim CEO appointment, board turnover increases.

One potential reason for the mixed results in prior research on director consequences of forced turnovers is that these studies all focus on future directorships as the outcome variable, which is a noisy proxy for director reputation and subject to endogeneity concerns as explained above. We add to this literature by establishing a link between forced CEO turnovers and shareholder satisfaction as measured through director re-elections, an arguably cleaner and more granular director reputation measure. Moreover, our results complement those in Ellis et al. (2020). They find that directors learn from forced CEO turnovers but seem not to be rewarded for this learning experience. Our results show that forced turnovers are associated with a significant reputation loss as turnover-experienced directors receive more withheld votes in subsequent re-elections and are not rewarded with additional board seats or board seats at larger firms. Taken together, our results suggest that the reputation effects we document dominate the learning effects found in Ellis et al. (2020).

Second, our paper contributes to the literature on CEO turnovers. Many studies resort to forced CEO turnovers as an outcome variable when analyzing the benefits of good corporate governance (e.g., Huson 
et al., 2001, Faleye, 2007, Jenter \& Kanaan, 2015, Kempf et al., 2017, Dasgupta et al., 2018). This choice is supported by the empirical observation that stock prices typically react positively to forced CEO turnover announcements (e.g., Borokhovich et al. 1996; Huson et al., 2001, 2004). However, short-term event studies around the turnover announcement may not capture the market's overall assessment of the board's performance in monitoring and eventually firing the CEO as CEO turnovers usually follow extended periods of poor company performance. Therefore, the market may greet the eventual decision to fire a poorly performing CEO. However, the overall assessment of the board's willingness and ability to monitor and, if necessary, replace the CEO may depend on how much value was destroyed before the eventual turnover decision was taken. Moreover, the announcement returns of short-term event studies around CEO turnovers may reflect differences in the dismissed CEO's qualities and her announced (or anticipated) successor. We add to this literature by measuring investors' assessment of forced CEO turnovers through directors' vote outcomes at directorships held at other firms as a proxy for director reputation. Our setting allows us to separate idiosyncratic turnover firm characteristics as well as specific aspects of these turnovers from shareholders' assessment of forced CEO turnover decisions. Our results show that forced CEO turnovers are associated with a significant reputational loss for involved directors. This finding contradicts the general presumption in the extant literature that forced CEO turnovers are a credible signal of the boards' monitoring ability and indicate well-functioning corporate governance. Instead, our findings suggest that forced CEO turnovers are perceived as a signal of failure in hiring and monitoring the $\mathrm{CEO}$ and, thus, indicate a governance failure.

\section{Sample and data}

\subsection{Sample selection}

To compile our CEO turnover sample, we start by identifying all CEO departures from S\&P 1500 firms between January 2003 and December 2017 in BoardEx. We then conduct extensive news searches in Factiva to identify the exact departure announcement date, the name of the replacement, whether the replacement was announced together with the departure, and the respective CEO departure circumstances. We drop departures where the news coverage indicates that a CEO departure results from the firm being acquired, the firm acquiring another company, or the firm selling or spinning off parts of its business because such events often indicate a firm's strategic realignment. Also, we drop departures where the CEO departure results from an ongoing proxy fight or is induced by government involvement because such turnovers are often not entirely at the discretion of the board of directors. Additionally, we remove all CEO departures for which we cannot find sufficient board meeting data in ISS. This leaves us with a sample of 1,773 CEO departure events involving 1,739 CEOs at 1,266 firms; the latter henceforth 
referred to as "turnover firms".

We follow previous literature, in particular, Parrino (1997), Peters \& Wagner (2014), and Jenter \& Kanaan (2015) in classifying these CEO turnovers as "forced" or "unforced". We directly classify a CEO turnover as forced if news articles indicate that the CEO is fired, is forced out of her position, or departs due to unspecified policy differences. Parrino (1997) argues that CEOs departing below the age of 60 should be treated with special care. He classifies such turnovers as forced if (1) the news articles covering the departure do not indicate that the CEO left due to poor health or acceptance of another position (elsewhere or within the firm) or (2) the articles report that the CEO is retiring but does not announce the retirement at least six months before the succession. Our classification procedure follows that of Parrino (1997) but, in an attempt to increase the precision of our forced turnover classification, adds one additional criterion: We classify CEO turnovers as unforced if the CEO does not leave the firm within one month after the announced departure date, which includes the termination of her board membership, but does not include remaining consulting positions at the turnover firm. The reason is that, after using Parrino (1997)'s original algorithm, we uncover that CEOs who are forced out of their role remain in an executive or board position at the turnover firm for an average of 1.49 years. Such a long lead-time between the departure announcement and the effective departure date suggests that the departure is not forced but consensual. The relatively short cut-off of one month aims at ensuring that our measure captures forced CEO turnovers only and, hence, that we can keep the number of false positives low. ${ }^{2}$ Our classification procedure results in $283(16 \%)$ CEO turnovers being classified as forced.

Following Jenter \& Lewellen (2019), we also classify the forced turnovers into performance-induced and non-performance-induced turnovers as reputational effects may differ across these two categories. ${ }^{3}$ We categorize 238 forced CEO turnovers as performance-induced and 38 forced CEO turnovers as not performance-induced. Seven turnovers cannot be classified as some of the required accounting and stock return data are missing.

Additionally, we categorize the forced CEO turnovers based on the turnover's timing within a CEO's tenure. Hambrick \& Fukutomi (1991) provide a descriptive model of a CEO's "seasons". They argue that, in the first years in office, CEOs contribute to firm performance positively as they increase their task knowledge by learning about their role within the firm and its environment. In later years, CEOs become more powerful and, as a consequence, more challenging to replace. They also rely on fewer information sources, become less willing or able to learn, and are less engaged, leading to declining performance.

\footnotetext{
${ }^{2}$ This additional criterion changes 128 CEO turnovers, classified as "forced" using Parrino (1997)'s algorithm, to unforced.

${ }^{3}$ Following Jenter \& Lewellen (2019), we classify a forced CEO turnover as performance-induced if the implied probability from Jenter \& Lewellen (2019)'s two-probit model is above 50\%. See Appendix A for a detailed description of the estimation.
} 
Overall, Hambrick \& Fukutomi (1991) predict an inverted U-shaped relation between CEO tenure and firm value. Turnovers that occur in the most productive period within a CEO's tenure, between three years and 13 years of tenure, may be perceived most negatively by the market. In our sample, 90 forced turnovers occur during the first three years of a CEO's tenure (the so-called "honeymoon period" according to Hambrick \& Fukutomi (1991)), 184 between three and 13 years of a CEO's tenure (the "harvest stage"), and 9 after a CEO was at the helm of the company for more than 13 years (the "decline stage").

Next, we identify all outside directors who serve at the 283 forced CEO turnover firms at the departure announcement date using BoardEx data. ${ }^{4}$ This gives us a sample of 2,183 outside directorships of 1,998 directors involved in a CEO turnover. We classify a director as interlocked if she serves as an outside director on the board of another firm besides the turnover firm at the forced CEO turnover announcement date. We identify 957 individual outside directors who hold at least one additional interlocked outside directorship. These directors are interlocked to 265 forced CEO turnovers.

Our main outcome variable is the share of withheld votes in director re-elections. Withheld votes are defined as the sum of votes withheld and votes against, divided by the total number of votes cast. We collect data on director re-elections from the ISS Voting Analytics database, which encompass shareholder votes of Russell 3000 firms from January 2003 onward. Our sample ends in December 2017. We then use fuzzy string matching to match the director names provided in ISS Voting Analytics to BoardEx. This procedure matches 40,443 individual outside directors at 6,640 firms in ISS to BoardEx, resulting in 199,667 director elections. To compute the change in votes withheld from one shareholder meeting to the next, we require at least two consecutive election observations per director-firm pair, resulting in a sample of 140,978 re-elections. For roughly one-third of our director-firm pairs, re-elections take place at firms with a staggered board. We keep these observations in our sample but remove director re-elections that are further apart than five years and re-elections that are closer than one quarter from the previous election. From this sample, we drop director re-elections for which we cannot retrieve sufficient stock price data from CRSP, accounting data from Compustat, institutional ownership data from Thomson Reuters, and board data from BoardEx and ISS, respectively. We also remove re-elections at financial or utility firms (SIC codes 6000-6999 and 4900-4999, respectively) because they operate in regulated industries. Finally, we remove re-elections at our turnover firms and re-elections of outside directorships

\footnotetext{
${ }^{4}$ We exclude inside (or executive) directors at both the turnover firms as well as our sample firms for several reasons. First, in the turnover firms, we exclude inside directors as primarily outside directors are responsible for monitoring and, if necessary, firing the CEO (e.g., Fama, 1980 Fama \& Jensen, 1983). Moreover, a large fraction of inside directors are actually the CEOs themselves. In the other cases, the inside directors depend on the CEO in their executive position making it more difficult to monitor and, if necessary, sanction the CEO. Second, outside directors are not involved in the daily business of the companies and thus may be less likely to be held accountable for a poor performance that eventually may trigger the turnover. Third, we exclude inside directors on the boards of our sample firms, as their vote results may depend more on an assessment of their executive roles and the perceived performance in this function than on their role in the board of directors (let alone the outside directorship at another firm).
} 
of the departing CEOs in our sample.

The resulting sample includes 88,406 director re-elections of 18,693 individual outside directors at 3,269 firms. 607 director re-elections concern directors interlocked to 206 forced CEO turnovers, while the remaining 87,799 director re-elections concern non-turnover-interlocked directors. ${ }^{5}$

\subsection{Descriptive statistics}

Table 1 reports summary statistics on the forced CEO turnovers and the corresponding interlocked directors in our sample. Panel A reports statistics on the turnover events. For the 206 forced CEO turnovers, we identify 607 interlocked outside directorships. In $45 \%$ of turnover announcements (or $45 \%$ of interlocked directorships), the turnover firms announce the appointment of a full replacement CEO together with the departure. In $88 \%$ of forced CEO turnovers (or $90 \%$ of interlocked directorships), we define the turnover as performance-induced using the classification of Jenter \& Lewellen (2019). 32\% of departures (or $31 \%$ of interlocked directorships) occur during the first three years of a CEO's tenure, $66 \%$ (or $69 \%$ of interlocked directorships) during years three to 13 of a CEO's tenure, and $2 \%$ (or $1 \%$ of interlocked directorships) after more than 13 years of a CEO's tenure.

Panel B of Table 1 reports descriptive statistics on the 607 interlocked directors' role in the turnover firms. About $50 \%$ of turnover-interlocked directors in our sample joined the turnover firm while the CEO was already in office. Such directors, appointed under the CEO's regency, are often referred to as "co-opted" directors (Coles et al. 2014). Finally, at the date of the departure announcement, $80 \%$ of the interlocked directors were members of either the nominating or the compensation committee, making them more responsible for monitoring the CEO.

Table 2 reports summary statistics on the directors interlocked to a forced CEO turnover and the interlocked firms on whose board they serve besides the turnover firm. This sample constitutes the treatment group in our analysis. Panel A reports characteristics of the interlocked directors. On average, these directors are 64 years old, are female in 17\% of all cases, and hold 3.1 additional board seats beside the one at the interlocked firm but including the one at the turnover firm. Panel B reports interlocked director characteristics related to the directorship at the interlocked (i.e., non-turnover) firms. Our main outcome variable is $\%$ votes withheld, which is defined as the sum of votes withheld and against at the director re-election, scaled by the total number of votes cast (e.g., Aggarwal et al., 2019). On average, turnover-interlocked directors receive $7.1 \%$ withheld votes. ISS recommends withholding votes for $7.4 \%$

\footnotetext{
${ }^{5}$ To measure the impact of a forced CEO turnover interlock on withheld votes, we need a re-election outcome before and after the interlocked CEO turnover. As a result, the majority of CEO turnovers in the years 2003/04 and 2016/17 drop out of our sample, leading to a final sample of 206 interlocked forced CEO turnovers.
} 
of the interlocked directors. Panel $\mathrm{C}$ reports summary statistics on the interlocked firms. On average, they hold 14.7 billion in total assets, generate around $14 \%$ operating returns, and institutional investors own $77 \%$ of their shares.

Table 3 replicates Table 2 for the non-turnover-interlocked directors and the firms on whose board they serve. This sample constitutes the control group in our analysis. Overall, turnover-interlocked directors are slightly older and hold more outside board seats than non-turnover-interlocked directors. Interlocked firms also tend to be larger, more profitable, and tend to have a larger share of institutional ownership than their control group counterparts. Most of the differences across the two samples are statistically significant, as indicated by the asterisks in Table 3 Some of the differences directly result from our sample construction. For instance, interlocked directors need to hold at least two board seats at the departure date, resulting in them holding a higher number of board seats than the control directors. The significant difference in the percentage of withheld votes, $7.1 \%$ in the treated versus $6.1 \%$ in the control sample, provides prima facie evidence of a potential negative reputation effect resulting from an interlock to a forced CEO turnover.

\section{The effect of forced CEO turnover on interlocked directors' vote shares}

\subsection{Univariate test of the reputational effect}

We first set out to test the reputational effect of forced CEO turnovers univariately. To this end, we compare the change in withheld votes in re-elections of directors interlocked to a firm with a forced CEO turnover to the change in withheld votes of directors not interlocked to a firm with a forced CEO turnover. We do so by estimating regressions of the percentage change of withheld votes on a treatment indicator, that is, a dummy variable that equals one if a director experienced a forced CEO turnover at another firm since the previous election date. We estimate this regression repeatedly for re-elections between three years before the interlocked forced CEO turnover to three years after the interlocked forced CEO turnover using up to three leads or lags of the CEO turnover interlock dummy. The coefficient estimates for the treatment indicator obtained in these regressions are displayed in Figure 1. In the absence of an interlocked forced CEO turnover, differences in changes in withheld votes between turnover-interlocked and non-turnover-interlocked directors are relatively small, ranging from -0.6 to +0.3 percentage points, and are statistically insignificant (light grey bars). However, following a forced CEO turnover, turnoverinterlocked directors experience a significant increase in withheld votes of 1.4 percentage points relative to non-turnover-interlocked directors (dark grey bar). This increase in withheld votes of 1.4 percentage points represents a $22.1 \%$ increase in withheld votes over the sample mean. Hence, these univariate results suggest that directors suffer a substantial reputational loss from interlocked forced CEO turnovers. 


\subsection{Multivariate tests of the reputational effect}

The previous section's results suggest that forced CEO turnovers are associated with negative reputational effects, as proxied by the change in the share of votes withheld. However, these results could be confounded by coinciding changes in a director's characteristics, such as a change in the number of outside board seats or firm-level changes at the interlocked firms, such as changes in performance. To control for such observable variation in director and firm-level attributes, we estimate the following difference-in-differences regression:

$$
\Delta_{i j} v_{i j t}=\beta T_{i j t, t-1}+\delta \Delta_{i j} X_{i t}+\theta \Delta_{i j} Z_{j t}+\alpha_{s t}+\varepsilon_{i j t}
$$

where $i, j, s$, and $t$ index director, firm, industry, and years, respectively. $\Delta_{i j}$ is the first-difference operator between two re-election meeting dates of director $i$ at firm $j .{ }^{6} v_{i j t}$ measures the fraction of votes withheld of director $i$ at firm $j$ in year $t$, in percent. $T_{i j t, t-1}$ is the treatment indicator, that is, a dummy variable equal to one if director $i$ was interlocked to a forced CEO turnover during the period between his re-election at firm $j$ in year $t$ and his previous re-election at firm $j . X_{i t}$ and $Z_{j t}$ are time-varying director- and firm-level control variables; $\alpha_{s t}$ are industry-year fixed effects. $\varepsilon_{i j t}$ is the usual error term. Standard errors are clustered at the industry level. ${ }^{7}$

By first-differencing withheld votes, we remove unobserved heterogeneity at the director-firm-pair level, similar to a specification in levels with director-firm fixed effects. Industry-year fixed effects remove unobserved industry effects, general time trends, and industry shocks. These steps ensure that the model captures the structural differences between the treatment and control samples, as discussed in section 2.2. As time-changing director controls, $X_{i t}$, we include the ISS vote recommendation and the number of additional outside board seats. Director characteristics such as age, tenure, and gender are removed due to their time-invariant nature. The set of time-varying control variables at the firm-level, $Z_{j t}$, is based on prior corporate governance and voting literature (e.g., Cai et al. 2009; Fischer et al., 2009 Matvos \& Ostrovsky, 2010, Aggarwal et al. 2019, Johnson et al., 2019), and includes board size, the fraction of outside directors on the board, the fraction of busy outside directors, the institutional ownership ratio, the natural logarithm of total assets, Tobin's Q, ROA, and past buy-and-hold returns. We winsorize Tobin's Q, ROA, and past buy-and-hold returns at the 1st and 99th levels to minimize the

\footnotetext{
${ }^{6}$ For most director-firm pairs, $t$ and $t-1$ refer to the year $t$ and $t-1$, respectively. However, in roughly one-third of our sample, firms do not re-elect all directors each year, but in a staggered manner. Therefore, the time-distance in the first-differencing differs across individual firms and directors based on the specific periodicity of the director re-elections. Hence, for directors of firms with a staggered board, $t$ and $t-1$ refer to the current $(t)$ and the last observable board meeting $(t-1)$ for which we observe election outcomes.

${ }^{7}$ Our results remain similar when we cluster the standard errors at the firm or the director level.
} 
effect of outliers.

The results from the difference-in-differences regression in Equation 1 are reported in Column 1 of Table

4. Results show that following a forced CEO turnover, turnover-interlocked directors receive an average of 1.20 percentage points more withheld votes than non-turnover-interlocked directors at firms in the same industry and year. This effect is similar in magnitude to the univariate effect shown in Figure 1 The economic magnitude of this effect is sizeable. The sample mean of non-turnover-interlocked directors is $6.1 \%$ (see Table 3). Thus, a 1.20 percentage point increase represents a $19.6 \%$ increase in withheld votes over the mean.

Looking at the control variables, results in Column 1 are generally consistent with prior research (e.g., Cai et al. 2009). For example, a change of ISS's recommendation from elect to withhold or vote against increases withheld votes by over 18 percentage points. Similarly, directors who gain board memberships subsequently receive more withheld votes. On the other hand, directors at a firm that improves performance or growth opportunities experience a reduction in withheld votes.

In Column 2, we add firm fixed effects to the model (alongside the industry-year fixed effects already included) to also absorb unobserved time-invariant firm-specific trends. We continue to find that turnoverinterlocked directors experience a significant increase of 0.88 percentage points withheld votes over nonturnover-interlocked directors at the same firm, or a $14.3 \%$ increase over the sample mean. In Column 3 , we augment our baseline regression from Column 1 with director fixed effects that remove unobserved time-invariant director characteristics. Our results again remain robust in this most conservative specification: Directors with an interlock to a forced CEO turnover face a significant increase in withheld votes of 1.03 percentage points, or a $16.8 \%$ increase versus the sample mean, as compared to re-elections of the same directors when there is no forced CEO turnover.

In summary, the results in this section suggest that interlocked directors suffer a reputational loss across all their board mandates following a forced CEO turnover. This finding contrasts the general presumption that forced CEO turnovers are a credible signal of the boards' monitoring ability and generally indicate good corporate governance.

\subsection{Cross-sectional tests: Directors neglecting their monitoring duty}

To corroborate our result that involvement in a forced CEO turnover is associated with a reputational loss for outside directors, we next test whether such a reputational loss is particularly pronounced for turnover events linked to poor (monitoring) performance of the board of directors.

In the first test, we analyze whether the reputational loss for outside directors involved in a forced 
CEO turnover depends on whether a successor to the dismissed CEO is announced simultaneously with the outgoing CEO's departure. Prior evidence paints a mixed picture regarding the impact of delayed CEO succession on firm performance. The majority of prior studies point towards a short-term decline in firm performance for firms with turnovers with interim successions (e.g., Ballinger \& Marcel, 2010. Mooney et al. 2017). However, firms might benefit in the long-run from taking more time to find a suitable successor, especially when the board does not have a succession plan in place (Rivolta, 2018). Nevertheless, Dalton \& Dalton (2007) argue that even after unforeseeable turnovers, the lack of an heir apparent to the outgoing CEO signals the board's unpreparedness and, thus, conveys a negative signal about the board's quality. Hence, the directors' reputation on the board is expected to suffer more if no full replacement is announced at the time of the announcement of the CEO's departure, even though such a delay may be beneficial for the turnover firm in the long run. To test whether the reputational loss of outside directors involved in forced CEO turnovers depends on whether a full replacement is announced along with the departure, we replicate Column 1 in Table 4 and split the variable Forced interlocked (d) into two variables, one indicating involvement into a forced CEO departure with a full replacement announced simultaneously (Forced interlocked $w$. full replacement $(d)$ ) and one without such an announcement (Forced interlocked w/o full replacement $(d)$ ). The results are reported in Column 1 of Table 5 Consistent with our conjecture, we find that outside directors involved in a forced CEO turnover at an interlocked firm with either an interim succession or no succession announced experience a large increase in the percentage of withheld shares of 1.5 percentage points, or an increase in $24.5 \%$ over the unconditional mean. This coefficient is statistically significant at the $1 \%$ level. In contrast, the coefficient for directors involved in a forced turnover with a full replacement announced is almost half this size (0.84 percentage points) and not quite significant at conventional levels. These results suggest that delayed successions in forced CEO turnovers are negatively assessed by shareholders compared to other departure announcements and increase the reputational loss of outside directors involved in forced CEO turnovers.

Ertugrul \& Krishnan (2011) argue that (forced) CEO turnovers should be separated into performanceinduced and non-performance-induced turnovers. They conjecture that non-performance-induced turnovers reflect a proactive board that steps in and fires an underperforming CEO before she can cause harm to firm value. On the other hand, performance-induced forced turnovers reflect a reactive dismissal since the board only acted once the damage was already done. Hence, we would expect the reputational damage from forced CEO turnovers to be worse for performance-induced dismissals. To test this conjecture empirically, we follow Jenter \& Lewellen $(2019)$ in classifying CEO turnovers into performanceinduced and non-performance-induced turnovers. Their estimation-based classification algorithm identifies performance-induced turnovers as departures that are "caused by bad performance, independently of whether the board or the CEO makes the decision" (p. 6). A detailed description of the estimation 
is provided in Appendix A of the paper. ${ }^{8}$ In Column 2 of Table 5 , we replicate our main specification in Column 1 of Table 4 and split the interlocked forced CEO turnover dummy into two dummy variables indicating performance-induced and non-performance-induced turnovers at interlocked firms. Consistent with our conjecture that the reputational damage from forced CEO turnovers is worse for reactive dismissals, we find the negative reputational effect following an interlocked forced CEO turnover to be confined to performance-induced turnovers. For such turnover events, we find a 1.4 percentage point increase in withheld votes or an increase of $23.0 \%$ versus the unconditional mean. In contrast, the coefficient on the non-performance-induced turnovers is negative and insignificant. These results imply that reactive forced CEO turnovers are perceived by shareholders as a bad signal for a board's quality, while proactive turnovers, i.e., those that likely pre-date poor company performance, are not.

An alternative way to measure the board's reactiveness to an underperforming CEO is to consider the timing of the forced departure within a CEO's tenure. In a descriptive model, Hambrick \& Fukutomi (1991) propose an inverted U-shaped relation between CEO tenure and firm value. Henderson et al. (2006) and Brochet et al. (2021) confirm such an inverted U-shaped relation empirically. Brochet et al. (2021), using a large sample of listed US companies similar to ours, find CEOs' value contribution to be positive over the first roughly 13 years and then turn negative. The CEO tenure literature suggests that during the first few years within a CEO's tenure, sometimes referred to as the "honeymoon stage", a newly appointed CEO gets to know the company and its board, experiments with different management and organizational styles, and eventually starts implementing changes. During this stage, the board of directors has the opportunity to assess whether the new CEO meets its expectations. A proactive board will fire a disappointing CEO during this stage to prevent future harm to shareholder value (Ertugrul \& Krishnan, 2011). Hence, we would not expect significant reputational damages for forced CEO turnovers during the honeymoon stage. After a successful honeymoon stage, the new CEO's organizational changes start to bear fruits, and the CEO enters the second "season", sometimes referred to as the "harvest stage". In the case of a poorly fitting CEO, who was still retained beyond the honeymoon stage, negative performance consequences will become observable. Hence, similar to performance-induced turnovers, forced CEO turnovers during the harvest stage may reflect a reactive board. We would thus expect reputational damages for directors involved in forced CEO turnovers taking place during this stage. Finally, after about 13 years of a CEO's tenure, the CEO's positive effects start to be outweighed by the adverse effects of increased power and entrenchment, even if the CEO was an excellent match to the firm initially (Hambrick \& Fukutomi, 1991 , Henderson et al., 2006, Brochet et al., 2021). During this

\footnotetext{
${ }^{8}$ Note that such algorithms are superior to text-based analysis in classifying performance-related and non-performance related CEO turnovers as the true reason behind CEO firings is often impossible to identify in press releases and company statements. Most companies issue generic press releases with vague reasons for the departure, often citing a mutual agreement between the board and the CEO on the need to step down.
} 
final stage, sometimes referred to as "decline stage", the CEOs' performance contribution turns negative. Therefore, we would expect no adverse reputational effects of CEO turnovers taking place during the decline stage. In Column 3 of Table 5 , we test this hypothesis by replicating our main specification in Column 1 of Table 4 and splitting the interlocked forced CEO turnover dummy into three dummy variables indicating these three life-cycle stages during which a CEO was forced out. Consistent with our conjecture, we find that the negative reputational effect following an interlocked CEO turnover is confined to turnovers during the harvest stage. For these turnovers, we find a 1.68 percentage point increase in withheld votes or an increase of $27.3 \%$ over the unconditional mean. In contrast, we find virtually no reputational effect of forced turnovers during the honeymoon stage or the decline stage. These results suggest that forced CEO turnovers that occur during the most productive period within a CEO's tenure are perceived as a bad signal for the directors' monitoring performance. Such turnovers may reflect an inactive board that took too long to recognize and correct a CEO-firm mismatch.

If the observed increase in withheld votes associated with a forced CEO turnover is the result of the market reassessing involved directors' ability and willingness to monitor senior management, we would expect directors with committee-based responsibility for monitoring the $\mathrm{CEO}$ and planning her succession to suffer larger reputational losses. The board committees generally entrusted with these responsibilities are the nominating and compensation committee (e.g., Chhaochharia \& Grinstein, 2009 Guo \& Masulis, 2015). To test empirically whether outside directors who are members of these committees at the turnover firm suffer larger reputational losses than non-member directors, we split the forced interlocked turnover variable in our baseline regression in Column 1 of Table 4 into two variables based on whether the director is a member of the nominating and/or compensation committee or not. The results are reported in Column 4 of Table 5 We find a statistically significant increase in withheld votes of 1.6 percentage points for members of the nominating and compensation committees, representing an increase of $25.5 \%$ over the unconditional mean. In contrast, the coefficient on the dummy indicating no membership in any of these two committees is negative and statistically insignificant at conventional levels. This result is consistent with the conjecture that committee membership-based responsibility for monitoring senior management, and in particular, the $\mathrm{CEO}$, is associated with a larger reputational loss following a forced CEO turnover.

Prior research shows that directors appointed after the current CEO resumed office (so-called co-opted directors) are favorably inclined to the $\mathrm{CEO}$ and thus provide weaker monitoring (e.g., Coles et al. 2014). Hence, involvement in a forced CEO turnover may reinforce the market's negative assessment of co-opted directors' monitoring capacity and their willingness to act in shareholders' interest. As a result, we would expect the reputational loss to be larger for co-opted outside directors involved in a forced CEO turnover than for non-co-opted directors involved in a forced CEO turnover. To analyze 
this conjecture empirically, we split our forced interlocked turnover dummy into two dummy variables depending on whether the director was appointed under the dismissed CEO. The results are reported in Column 5 of Table 5 . We find that the reputational loss associated with the involvement in a forced CEO turnover at an interlocked firm is larger for co-opted directors than non-co-opted directors. Both coefficients are positive, but the coefficient for the subset of co-opted directors is about twice the size of the coefficient for non-co-opted directors and statistically significant at the $1 \%$ level. With a magnitude of 1.7, this represents an increase of $27.2 \%$ over the unconditional mean. In contrast, the coefficient for non-co-opted directors is not quite significant at conventional levels. This result is consistent with the expectation that directors, who are affiliated with the CEO, may neglect their monitoring duty and suffer a more substantial reputational loss from a forced CEO turnover than unaffiliated directors.

Overall, the results in Table 5 show that the negative reputational effects from forced CEO turnovers onto interlocked directors are confined to turnover events in which directors have neglected their monitoring duty to corporate shareholders, as proxied with insufficient succession planning, reactive and late CEO dismissals, and turnovers that occur during the most productive period within a CEO's tenure. These turnover characteristics suggest a weak board of directors that is ill-prepared and acts late once the damage is already done. Moreover, our results suggest that directors with a committee-based responsibility for appointing and monitoring senior management and directors close to the dismissed CEO experience a particularly large reputational loss. Taken together, these results corroborate the findings from the previous sections. They show that, contrary to the general presumption, forced CEO turnovers are not a credible signal of the boards' monitoring ability and thus do not per se indicate good corporate governance.

\subsection{Who votes against turnover-involved directors?}

In this section, we analyze the channel through which directors involved in forced CEO turnovers are penalized. Specifically, we attempt to determine which shareholders tend to vote against directors involved in forced CEO turnovers at other firms. Penalizing directors for actions taken in interlocked firms requires shareholders to i) observe and evaluate directors' actions, ii) observe interlocked directorships, and iii) take action by systematically voting against involved directors across their board mandates. Institutional investors with significant ownership stakes in both the turnover and interlocked firms are those most likely fulfilling these requirements. Institutional investors are generally sophisticated investors (e.g., Gibson et al. 2004) who positively impact the governance of the companies in their portfolio, independent of whether they follow an active (e.g., Brav et al. 2008) or passive investment approach 
(e.g., Appel et al., 2016). ${ }^{9}$ Hence, we expect that turnover-interlocked directors receive more withheld votes at the interlocked firm if there is significant common ownership by institutional investors in both the interlocked and the turnover firm.

To test this conjecture empirically, we measure institutional investors' common ownership in the interlocked and turnover firms using the Thomson Reuters institutional holdings (13F) database. We identify all institutional investors that report holdings in the turnover firms at the last reporting date before the forced CEO turnover announcement and holdings at the turnover-interlocked firm at the last reporting date before the re-election meeting date of an interlocked director following the forced turnover. For each investor-turnover event pair, we consider the lower fraction of shares outstanding owned in the turnover firm and the turnover-interlocked firm as common ownership. We then sum up common ownership values across different investors on the turnover event-director re-election level. Finally, we construct dummy variables that are equal to one if common ownership of a specific turnover event-director re-election is above or below mean (median) common ownership in our sample and split the variable Forced interlocked (d) into two variables, one indicating involvement into a forced CEO departure with common ownership between the turnover and the interlocked firm above mean (median) common ownership (Forced interlocked $\geq$ mean (median) common own. (d)) and one with common ownership below its sample mean (median) (Forced interlocked $<$ mean (median) common own. (d)).

Results from re-estimating our baseline regression with the Forced interlocked (d) variable split according to mean common ownership are reported in Column 1 and according to median common ownership in Column 2 of Table [6] We find that outside directors involved in a forced CEO turnover at an interlocked firm with above mean (median) common ownership experience an increase in the percentage of withheld votes that is larger by $60 \%$ (74\%) than the increase in withheld votes in response to interlocked forced CEO turnovers with below mean (median) common ownership. These results indicate that the negative vote effect of being involved in a forced CEO turnover at an interlocked firm mostly stems from institutions with significant joint ownership in both the turnover and the interlocked firms.

This section's findings support the notion that informed institutional investors engaged in monitoring both the turnover firms and the interlocked firms are responsible for penalizing directors. Moreover, these results suggest that the recent growth in institutional shareholdings and concentration of ownership in the portfolios of a few large asset managers, which raised anti-competition concerns (e.g., Azar et al.

\footnotetext{
${ }^{9}$ BlackRock, the world's largest institutional investor based on Assets under Management acted on various concerns by opposing 5,100 director re-elections globally between July, 2019 and June 30, 2020. Notably, BlackRock penalizes directors across all of their board mandates, for instance for holding too many board seats. For more information see BlackRock's 2021 proxy voting guidelines (https://www.blackrock.com/corporate/literature/fact-sheet/ blk-responsible-investment-guidelines-us.pdf) and their 2021 stewardship expectations guideline (https://www. blackrock.com/corporate/literature/publication/our-2021-stewardship-expectations.pdf)
} 
2018), might also have a so-far unrevealed positive consequence: Large ownership shares and substantial cross-shareholdings facilitate monitoring of individual directors across multiple firms and thereby provide stronger incentives for directors to perform.

\subsection{Reputation loss versus director distraction}

An alternative interpretation to our reputation-based explanation of the increase in withheld votes at interlocked firms following a forced CEO turnover is director distraction. A forced CEO turnover may demand significant time and effort from directors involved in the process. Consequently, turnoverinterlocked directors have less time for their board duties at interlocked firms and may be penalized by the interlocked firms' shareholders at the next re-election. Such an explanation would be in line with Masulis \& Zhang (2019) and Stein \& Zhao (2019), who associate increased director distraction, including CEO turnovers, with reduced monitoring efficiency at interlocked firms.

In this section, we conduct two tests of the director distraction hypothesis. The first test explores sudden CEO deaths. Falato et al. (2014) show that following the sudden death of a fellow director, directors within the same committee as the deceased colleague experience a workload increase that negatively impacts their attention at interlocked directorships. The sudden death of a CEO likely requires even more attention and time of the board of directors than sudden director deaths. Moreover, the sudden death of a CEO is, by definition, outside the board's control and thus expected to have no reputational effects on the directors since such deaths are unlikely to reveal anything about the director's (monitoring) capabilities. Thus, if our results are driven by director distraction, we would expect to observe an increase in withhold votes for directors who experience the sudden death of a CEO at another firm on whose board they serve. To test this empirically, we re-estimate the baseline regression in Column 1 of Table 4. augmented with an additional explanatory variable, namely a dummy equal to one if the director is interlocked to another firm that experiences a sudden death of the CEO. To construct this variable, we search for CEO departures caused by sudden deaths as defined by Nguyen \& Nielsen (2010) and others during our sample period from January 2003 to December 2017. We identify 10 sudden CEO deaths in our sample of S\&P 1500 firms, resulting in 29 death-interlocked directorships. To augment sample size, in an alternative specification, we extend our measure of death-interlocked directorships by 11 directorships that are interlocked to four announcements of an unexpected CEO sick leave during which the CEO subsequently dies, resulting in a total of 40 death-interlocked directorships. ${ }^{10}$ Results are reported in Columns 1 and 2 of Table 7 Consistent with our reputation-based explanation but inconsistent with a distraction-based explanation, the coefficients on the dummy variables indicating

\footnotetext{
${ }^{10}$ To ensure that these later deaths still constitute a similar shock to the turnover firm as a sudden death, we restrict the extension to subsequent deaths that happen within 30 days of the sick leave announcement.
} 
an interlocked outside directorship to a firm experiencing the CEO's death are statistically insignificant across both columns.

In a second test of the director distraction hypothesis, we consider other board members who share committee memberships with turnover-interlocked directors. In our setting, the distraction hypothesis postulates that directors involved in a forced CEO turnover deviate their attention away from the interlocked firm towards the turnover firm. Consequently, other directors at the interlocked firms that share committees with turnover-interlocked directors will take over a part of the turnover-interlocked director's committee responsibilities. Hence, within turnover interlocked firms, there are spillover effects in director inattention from the turnover-interlocked directors to their committee-peers (Falato et al. 2014$)$. Therefore, if our results are driven by director distraction, committee-peers of turnover-interlocked directors would be expected to suffer a significant increase in withheld votes as well. We test this conjecture empirically by re-estimating the baseline regression model in Column 1 of Table 4 augmented with a dummy equal to one if the director shares a committee with a turnover-interlocked director. To identify such committee peers, we focus on the four main board committees, i.e., nominating, compensation, corporate governance, and audit committee, since these committees are typically the most important and labor-intensive committees (Masulis \& Zhang, 2019). We identify 1,628 director re-elections of directors who share at least one committee with 600 turnover-interlocked directors. ${ }^{11}$ Compared to the tests exploring sudden CEO deaths, this test benefits from a substantially larger number of directors subject to workload increases. Column 3 of Table 7 presents the results. Consistent with our reputationbased explanation, but inconsistent with a distraction-based explanation, the coefficient on the dummy variable indicating a shared committee membership with a turnover-interlocked director is statistically insignificant.

Overall, the results in this section show that exogenous shocks, which are confined to the workload of directors but do not reveal any information on directors' monitoring capabilities, do not result in increases in withheld votes. Hence, this analysis suggests that our results are not caused by director distraction but by shareholders reassessing individual directors' capabilities to hire, monitor, and fire CEOs.

\footnotetext{
${ }^{11}$ We lose seven turnover-interlocked director observations from our sample because we find no data on committees or committee memberships for three observations and no committee-peers for four observations.
} 


\section{Internal validity}

\subsection{Parallel trends, treatment reversal, pseudo treatments, and selection issues}

The identifying assumption central to any difference-in-differences analysis is that treated and control observations share parallel trends before the onset of treatment. Specifically, conditioning on time-varying director controls $\left(X_{i t}\right.$ in Equation 11), time-varying firm controls $\left(Z_{j t}\right)$, and industry-year fixed effects $\left(\alpha_{s t}\right)$, turnover-interlocked directors (treated directors) and non-turnover- interlocked directors (control directors) need to show parallel trends in their re-election results prior to the onset of treatment. Figure 1 shows the differences in the change in withheld votes between the treatment and control groups for a symmetric window covering seven re-elections around the interlocked forced CEO turnover. For the three re-elections before an interlocked forced CEO turnover, there are no significant differences in the changes in withheld votes between turnover-interlocked and non-turnover-interlocked directors. This implies that treated and control directors do not differ in their votes before the onset of the treatment, thus supporting the notion that the parallel trends assumption holds.

To test whether there is evidence of a treatment reversal following the CEO turnover event, we rerun the baseline regression with additional lags for one and two re-election dates, respectively. Columns 1 and 2 in Table 8 report the results. In both regressions, our treatment indicator's coefficient remains economically large and statistically significant, and both lagged variables are small in magnitude and statistically insignificant. As the dependent variable is the change in the percentage of withheld votes, these results suggest that a forced CEO turnover results in a persistently higher level in withheld votes at re-elections of the directors involved in a turnover event at another firm. This finding is consistent with a reputational loss for outside directors involved in forced CEO turnovers. It suggests that turnovers, if not managed well, may have a persistent negative reputational effect.

Additionally, we run falsification tests where treatment is set to t-1 and t-2, respectively. Hence, we look at re-elections that take place before the forced CEO turnover. Columns 3 and 4 of Table 8 present the results of these pseudo treatment regressions. In both regressions, the coefficient on the treatment indicator is small and statistically insignificant, suggesting that the observed changes in the percentage of withheld votes are due to the forced CEO turnovers at the interlocked firm, as opposed to alternative factors, such as deteriorating firm performance which precedes the CEO turnover at the turnover firm.

Another potential concern with our analysis is a selection bias that results from our identification strategy. Specifically, obtaining treatment status requires interlocked directors to hold at least two outside directorships at the time of the turnover - one at the turnover firm and one at the interlocked firm. In contrast, outside directors in the control group are generally not required to hold multiple board seats. In 
fact, turnover-interlocked directors on average hold 1.4 boards seats more than non-turnover-interlocked directors (see Tables 2 and 3). However, such a selection bias is unlikely to drive our results for two reasons. First, by first-differencing at the director-firm level and including the change in the number of outside board seats in our regression models as a covariate, we control for unobserved director-specific effects and effects related to changes in the number of board seats. Second, our results hold when we add director fixed effects to our regressions, which also control for potential selection effects at the directorlevel. Nevertheless, we rerun our main analysis on a sample that excludes all non-turnover-interlocked directors who hold no additional board seats. The results on this restricted sample are reported in Table C.1 and are virtually identical to the main results in Table 3.2 Hence, a selection bias resulting from our identification strategy is unlikely to drive our results.

In summary, this section's analyses show that there is no significant difference in the change in withheld votes between turnover-interlocked and non-turnover-interlocked directors before or after the turnover, confirming that the parallel trends assumption holds. The fact that the increase in withheld votes is confined to the turnover event and does not revert subsequently implies that the negative reputational effects persist. Moreover, a selection bias resulting from the requirement that treated, i.e., interlocked, directors have to hold at least two outside directorships, is unlikely to affect our results.

\subsection{Simultaneity and reverse causality}

A further potential concern with our interpretation of the results is that both a forced CEO turnover at the turnover firm and an increase in withheld votes at the interlocked firm may be the result of poor performance at the turnover firm. Specifically, firms that experience poor stock price performance are more likely to force out their CEO (e.g., Dasgupta et al., 2018; Fee et al., 2018). As poor firm performance can also be linked to bad monitoring, investors might simply penalize directors interlocked to poorly performing firms rather than directors involved in forced CEO turnovers (e.g., Klein, 1998 , Brick \& Chidambaran, 2010). Under this alternative interpretation, causality would not run from forced CEO turnovers to an increase in withheld votes at turnover-interlocked firms: Both the CEO turnover at the turnover firm and the increase in withheld votes at the turnover-interlocked firm would be caused by poor firm performance of the turnover firm.

Alternatively, our results may be driven by reverse causality. Fos et al. (2018) find that the CEO turnover-performance sensitivity increases before director re-elections. Directors under threat of increased withheld votes might feel inclined to fire their CEO to signal functioning corporate governance. Under such a scenario, the increase in withheld votes at interlocked firms might reflect a general increase in withheld votes for the turnover-interlocked directors across all their board seats that started already 
before the directors decided to force out their CEO. The forced CEO turnover might then be the result of an increase in withheld votes, rather than the other way around.

To ensure that causality indeed runs from forced CEO turnovers to increases in withheld votes at turnover-interlocked firms, we conduct a propensity score matching analysis, in which we match CEO turnover firms to non-turnover firms with the same propensity to experience a forced CEO turnover. We then compare withheld votes of directors interlocked to firms with a forced CEO turnover to withheld votes of directors interlocked to firms with a similar propensity to experience a forced CEO turnover but without a turnover. By doing so, we obtain balanced treatment and control samples of directors who are interlocked to firms that are similar in terms of the likelihood to fire the CEO but differ only in the effective turnover decision.

We calculate propensity scores using two different regression models. In the first model, we calculate propensity scores using the forced turnover likelihood model introduced by Peters \& Wagner (2014). ${ }^{12}$ In the second model, we extend Peters \& Wagner (2014)'s model by an additional variable that measures the mean change in withheld votes across all director re-elections from the most recent annual meeting before the matching date. At each forced CEO departure announcement date in our sample, we construct all control variables necessary to estimate the model for every S\&P 1500 firm within our sample using ISS, BoardEx, Compustat, and CRSP. From this panel, we remove all potential control firms that experience a forced CEO turnover within five years before or after the turnover. This ensures that our sample of matched control firms does not include "forced CEO turnover firms in disguise", that is, firms that have very recently forced out their CEO or will soon force out the CEO. Additionally, we remove all firm-turnover observations for which we find no outside directors with interlocked directorships at other firms or no vote share data at the interlocked firms. Our final sample for the propensity score matching consists of 160,311 potential control firm-turnover-pairs of 1,822 distinct potential control firms spanning 183 forced CEO turnovers for the original Peters \& Wagner (2014) model, and 115,760 potential control firm-turnover-pairs of 1,710 distinct potential control firms spanning 149 forced CEO turnovers for the extended model, respectively. A covariate balance test between the turnover firms and the potential control firms for both models is presented in the Appendix in Tables D.2 and D.4 respectively. Absent any matching, most of the variables differ significantly across the two samples.

The results of the propensity score estimations are presented in the Appendix in Table D.1. Within each

\footnotetext{
${ }^{12}$ We follow the suggestion in Peters \& Wagner $(2014)$ to use a logistic regression. Peters \& Wagner (2014) use a linear probability model instead because they use the forced turnover likelihood model as a first stage in a two-stage model and, to ensure consistency with the second stage, resort to a linear probability model in the first stage as well.
} 
turnover stratum, we identify the control firm with the closest propensity score to the turnover firm. ${ }^{13}$ We find nearest neighbors for 181 of the 183 turnover events in our sample for the original model and 147 of the 149 turnover events in our sample for the extended model. A covariate balance test between the turnover and matched control firms, as well as an illustration of common support are presented in the Appendix in Table D.3 and Figure D.1 and Table D.5 and Figure D.2 respectively. The results in the covariate balance test tables show that none of the variables used in the propensity score analysis differ significantly between the turnover and the control sample. Similarly, both figures show that the density distribution of the propensity scores for turnover and matched firms align closely across the full propensity score spectrum.

For each firm in our propensity score-matched samples, we identify all outside directors who also hold outside directorships at other firms in our vote shares sample, following the same methodology described in Section 2 For the original model, we find data for 525 turnover-interlocked directorships held by 383 individual directors at 411 turnover-interlocked firms, and 586 matched non-turnover-interlocked directorships held by 418 individual directors at 453 matched non-turnover-interlocked firms. For the extended model, we find data for 439 turnover-interlocked directorships held by 317 individual directors at 362 turnover-interlocked firms, and 495 matched non-turnover-interlocked directorships held by 337 individual directors at 381 matched non-turnover-interlocked firms.

Using the matched sample, we estimate regressions similar to our baseline regressions in Table 4 However, the propensity score-matched sample is naturally cross-sectional, and thus, the dependent variable is in levels and not changes. Moreover, as the propensity score matching balances the matched sample on the treatment firms only, we include control variables for interlocked directors and the interlocked firms. Table 9 Columns 1-3, present the results from the analysis on the matched sample using the original propensity scores model. Column 1 reports results from a regression without fixed effects. The regression reported in Column 2 additionally includes industry and year fixed effects. In Column 3, we augment the baseline regression with turnover event fixed effects. This most restrictive specification compares withheld votes between turnover-interlocked directors and matched non-turnover-interlocked directors interlocked to firms that have a similar propensity to replace the CEO but do not force her out. Across all three columns, we find that directors interlocked to firms that forced out their CEO receive significantly more withheld votes than directors interlocked to firms with the same propensity of forced CEO turnover but no actual CEO turnover event. The magnitude of the coefficients in Columns 1 and 2 is virtually identical to the forced turnover-interlocking coefficient in the baseline regression in

\footnotetext{
${ }^{13}$ We improve this standard matching procedure by imposing a maximum caliper width, i.e., a maximum allowed distance between the turnover and control firms' propensity score (e.g., Austin, 2011a Lechner \& Strittmatter, 2019). We follow Austin (2011b), who identifies an optimal caliper width of 0.2 times the pooled standard deviation of the logit of propensity scores.
} 
Column 1 of Table 4 The coefficient in the very restrictive specification in Column 3 is still marginally significant and economically sizeable, indicating that interlocked directors receive an average of 1.01 percentage points more withheld votes than non-turnover-interlocked directors, an increase in withheld votes of $16.5 \%$ over the sample mean of non-turnover-interlocked directors.

Table 9. Columns 4-6, report results from the analysis of the matched sample that is based on the extended propensity score model. This matched sample is well balanced in terms of pressure at the turnover firm that stems from director re-elections before the forced CEO turnover date and is thus expected to capture a potential impact of director re-election outcomes on forced CEO turnovers. Column 4 reports results from a regression without fixed effects, and Column 5 reports results from the same regression augmented with industry and year fixed effects. Column 6 reports results from a regression that includes event fixed effects. Across all three columns, we find that directors interlocked to firms that forced out their CEO receive significantly more withheld votes than directors interlocked to firms with the same propensity of a forced CEO turnover but no actual turnover event.

In summary, the results in this section show that neither poor performance nor negative re-election vote pressure at the turnover firm drive our results. Instead, these results suggest that causality runs from forced $\mathrm{CEO}$ turnovers to increases in withheld votes at turnover-interlocked firms. ${ }^{14}$

\section{The effect of forced CEO turnover on directors' board seats}

So far, we have shown that involvement in a forced CEO turnover has negative reputational effects on involved directors, as measured by the percentage of withheld votes at interlocked firms. These reputational effects may extend into the director labor market and affect the career prospects of turnoverinterlocked directors. For instance, Aggarwal et al. (2019) show that directors who suffer an increase in withheld votes in uncontested director elections are more likely to undergo committee demotions and board turnovers and sustain reduced director labor market opportunities. Similarly, Johnson et al. (2019) find that directors involved in adopting a poison pill suffer reputational damage that impacts their career outlooks. Consequently, we would expect that, following a forced CEO turnover, outside directors involved in the turnover lose outside directorships or at least do not gain further outside directorships.

To analyze this conjecture empirically, we run analyses that are akin to a difference-in-differences setting. Specifically, we analyze changes in board seats between the forced CEO turnover announcement date

\footnotetext{
${ }^{14}$ These tests also address the concern that our baseline estimates are biased because of an imbalance in the sample size between treated and control samples. Given that we continue to find results very similar to our baseline regression, it seems unlikely that a sample size imbalance drives the result in our main analysis.
} 
and up to five years after the turnover (first difference) and compare these changes between turnoverinterlocked directors and non-turnover-interlocked directors (second difference). To construct the sample underlying these analyses, we use our vote share sample and retain all outside directors of turnoverinterlocked firms at the departure announcement date. Using BoardEx, we then collect data on all other outside directorships these directors hold at the CEO departure date and all directorships they gain or lose within one and five years after the interlocked forced turnover.

Our first outcome variables are two dummy variables equal to one if a director loses at least one of her directorships within one or five years following the forced CEO turnover, respectively, and zero otherwise. Table 10 reports the results of OLS regressions of these dummy variables on a treatment dummy indicating whether a director is turnover-interlocked and a set of director controls. Columns 1 and 2 consider a one-year horizon for the loss in board seats following the turnover, while Columns 3 and 4 use a five-year horizon. Columns 1 and 3 include turnover fixed effects, and Columns 2 and 4 additionally include turnover-interlocked firm fixed effects. The coefficients on the dummy variable indicating an interlock to a forced CEO turnover are positive and significant at the $5 \%$ level or higher across all four columns, suggesting that involvement in a forced CEO turnover indeed increases the likelihood of losing board seats. Our estimates' economic magnitude ranges from 7.2 percentage points over a one-year horizon (Column 1) to 9.7 percentage points over a five-year horizon (Column 4). The unconditional probability of losing a directorship in our sample is $13.1 \%$ and $46.0 \%$ over a one-year and five-year period, respectively. Hence, the treatment effect's economic magnitude is sizeable: An involvement in forced CEO turnover increases the probability of losing a directorship by $55 \%$ versus the sample mean over one year and $21 \%$ over five years.

In Table 11, we perform several additional tests related to the loss (and potential gain) of directorships. First, we test whether the loss in directorships following a forced CEO turnover is driven by a loss in directorships at the turnover firm. To this end, we omit the directorship at the turnover firm when computing our dependent variables. Results are reported in Panel A of Table 11 We find that the coefficients on the forced interlocked dummy turn insignificant across all four columns. Hence, the loss in directorships documented in Table 10 is driven by the loss of the directorship at the turnover firm. Next, we test whether directors can make up for the lost board seats at the turnover firm by gaining board seats at other firms. To this end, we repeat the analysis in Panel A and replace the dependent variable with dummy variables that are equal to one if a director gains at least one new directorship within either one or five years following the turnover, respectively, and zero otherwise. Results are reported in Panel $\mathrm{B}$ and show that turnover-interlocked directors are significantly more likely to gain new board seats five years after the forced CEO turnover, but not within one year after the turnover. Five years after the turnover, the likelihood of gaining a new board seat is 8.0 percentage points (Column 3) and 8.7 
percentage points (Column 4) higher for turnover-interlocked directors versus non- interlocked directors, respectively. These coefficient estimates are very similar in magnitude to those for directorship losses reported in Columns 3 and 4 of Table 10 suggesting that the gains in directorships at other firms reported in Panel B of Table 11 substitute for the losses of directorships at the turnover firms. To empirically test the conjecture of such substitution effects, in Panel C, we replicate the analysis in Table 10 using the net losses/gains of outside directorships as the dependent variable. The results confirm our conjecture: Directors involved in a forced CEO turnover on average have an around $7 \%$ higher likelihood of losing a directorship in the first year after the turnover (Columns 1 and 2). However, this initial loss, driven by the loss of the directorship at the turnover firm, is offset by a higher likelihood of gaining outside directorships in subsequent years, as shown in Panel B. As a result, net losses of directorships five years after the turnover do not differ significantly between turnover-interlocked directors and non-turnover interlocked directors on the boards of the same (interlocked) firms.

A reputational loss may not only show in the number of outside directorships but also in the quality of these directorships. In general, board seats at larger firms are associated with higher compensation packages (Ryan \& Wiggins, 2004), more power and prestige (Shivdasani, 1993, Adams \& Ferreira, 2008. Masulis \& Mobbs, 2014), and networking benefits (Yermack, 2004; Fich, 2005). Hence, we analyze the change in the aggregate total assets represented by all firms at which a director holds an outside board seat over the first year after the turnover or the first five years after the turnover. ${ }^{15}$ To account for the skewness in the distribution of this variable, we apply the hyperbolic sine transformation to the total assets change (Burbidge et al. 1988). ${ }^{16}$ Results are reported in Panel A of 12 . They show that turnover-interlocked directors experience a significant decline in aggregate total assets represented by their board seats compared to non-turnover-interlocked directors. However, when omitting the turnover firms from the analysis, as in Panel B, we find no significant difference in the change of aggregate total assets represented by all board seats between turnover-interlocked directors and non-turnover-interlocked directors across both the one- and five-year horizons. Hence, board seats lost at the turnover firms tend to be replaced by new board seats over the next five years, as discussed above. However, these board seats tend to be at smaller firms, resulting in a decline in total assets represented by the entire portfolio of firms at which turnover-interlocked directors hold board seats.

Finally, we test whether the cross-sectional patterns on vote outcomes described in Section 3.3 and reported in Table 5 also hold in the analysis using changes to board seats as dependent variable. Consistent with the results on vote outcomes, we find that directors are more likely to lose board seats if there is no

\footnotetext{
${ }^{15}$ In Table E.1. we replicate the analysis in Table 12 using the change in market capitalization instead of the change in total assets and find very similar results.

${ }^{16}$ Note that we cannot use the natural logarithm of the change in total assets (or market capitalization) as these changes can take on negative and positive values.
} 
full succession in place if the forced turnovers are performance-induced, and if the turnover occurs during the most productive period within a CEO's tenure. In addition, we find that directors who are affiliated with the departing $\mathrm{CEO}$ and directors with a committee-based monitoring role towards the CEO are most likely to lose board seats. These results confirm that CEO turnovers in which involved directors failed to perform their duty to hire, monitor and fire CEOs in a timely and value-preserving manner are associated with stronger reputational losses, confirming the idea that CEO turnovers tend to rather be the result of a governance failure than the realization of a well-functioning governance system. Finally, consistent with results reported in Panel A of Table 11, we find no significant cross-sectional patterns if turnover firms are excluded from the sample. ${ }^{17}$

In summary, the results in Tables 12 and E.1 provide some support for our conjecture that involvement in a forced CEO turnover results in a reputational loss for outside directors: Directors who experience a CEO departure tend to lose board seats, primarily at the firm at which they experience the turnover, and it takes up to five years to make up for the board seat lost because of the turnover. Moreover, the board seats that the turnover-experienced directors regain tend to be at smaller firms. While generally consistent with a reputational loss following forced CEO turnovers, these results are less conclusive than the vote results presented above. However, it is important to note that future board seats may be subject to endogeneity concerns, in particular, that directors may choose to either terminate some board seats or attempt to solicit new board appointments for multiple reasons unobservable to the researcher (Ertimur et al. 2012, Levit \& Malenko, 2016).

\section{Conclusion}

Hiring and firing the top management of a corporation is one of the primary tasks of the board of directors (e.g., Fama, 1980 Fama \& Jensen, 1983). Yet, evidence on the consequences of forced CEO turnovers on outside directors responsible for monitoring and, if necessary, firing the CEO is scarce. Such an analysis is empirically challenging as the turnover decision is endogenous and usually related to company performance (Fee et al. 2013). Moreover, the outcome variables commonly used to measure reputational effects for turnover-interlocked directors, such as changes in the number of future board memberships, are subject to endogenous selection (Levit \& Malenko, 2016). We overcome these challenges by using the percentage of withheld votes in director re-elections as our primary outcome variable and observing this outcome at interlocked directorships, which are not affected by the factors that led to the forced CEO turnover.

\footnotetext{
${ }^{17}$ Results on cross-sectional patterns of losses of board seats are not reported in a table for space reasons but are available from the authors upon request.
} 
Our results establish novel evidence on the reputational effects of forced CEO turnovers on directors involved in the turnover decision. In particular, we find that directors interlocked to a forced CEO turnover experience an economically large and statistically significant increase in the share of withheld votes at subsequent director re-elections, suggesting that they suffer a negative reputational effect from the CEO turnover. When investigating the drivers of this reputational loss, we find that the adverse reputational effects are confined to forced departures without a successor in place, performance-induced turnovers, and turnovers that occur during the most productive time period within a CEO's tenure. Additionally, we show that there is significant heterogeneity in shareholders' votes following the turnover, depending on the directors' committee-based role in monitoring the CEO and their affiliation to the CEO. These results show that the negative reputational effects from forced CEO turnovers onto interlocked directors are confined to turnovers in which directors have neglected their monitoring duties towards the CEO.

The results presented in this paper challenge the widely accepted view that forcing out a CEO is a sign of well-functioning corporate governance at the firm-level. Our results, which show that directors on average suffer a reputational loss from involvement in a CEO turnover, support an alternative view: Depending on the timing and circumstances of the turnover, forcing out a CEO can be perceived as a signal of failure in the hiring and monitoring of the CEO, and thus end up being detrimental to a director's reputation. 


\section{References}

Adams, R. B., \& Ferreira, D. (2008). Do director's perform for pay? Journal of Accounting and Economics, 46, 154-171.

Aggarwal, R., Dahiya, S., \& Prabhala, N. R. (2019). The power of shareholder votes: Evidence from uncontested director elections. Journal of Financial Economics, 133, 134-153.

Appel, I. R., Gormley, T. A., \& Keim, D. B. (2016). Passive investors, not passive owners. Journal of Financial Economics, 121, 111-141.

Austin, P. C. (2011a). An introduction to propensity score methods for reducing the effects of confounding in observational studies. Multivariate Behavioral Research, 46, 399-424.

Austin, P. C. (2011b). Optimal caliper widths for propensity-score matching when estimating differences in means and differences in proportions in observational studies. Pharmaceutical Statistics, 10, 150161.

Azar, J., Schmalz, M. C., \& Tecu, I. (2018). Anticompetitive effects of common ownership. Journal of Finance, 73, 1513-1565.

Ballinger, G. A., \& Marcel, J. J. (2010). The use of an interim CEO during succession episodes and firm performance. Strategic Management Journal, 31, 262-283.

Borokhovich, K. A., Parrino, R., \& Trapani, T. (1996). Outside directors and CEO selection. Journal of Financial and Quantitative Analysis, 31, 337.

Brav, A., Jiang, W., Partnoy, F., \& Thomas, R. (2008). Hedge fund activism, corporate governance, and firm performance. Journal of Finance, 63, 1729-1775.

Brick, I. E., \& Chidambaran, N. K. (2010). Board meetings, committee structure, and firm value. Journal of Corporate Finance, 16, 533-553.

Brochet, F., Limbach, P., Schmid, M., \& Scholz-Daneshgari, M. (2021). CEO tenure and firm value. The Accounting Review, forthc..

Brochet, F., \& Srinivasan, S. (2014). Accountability of independent directors: Evidence from firms subject to securities litigation. Journal of Financial Economics, 111, 430-449.

Burbidge, J. B., Magee, L., \& Robb, A. L. (1988). Alternative transformations to handle extreme values of the dependent variable. Journal of the American Statistical Association, 83, 123-127.

Cai, J., Garner, J. L., \& Walkling, R. A. (2009). Electing directors. Journal of Finance, 64, 2389-2421. 
Chhaochharia, V., \& Grinstein, Y. (2009). CEO compensation and board structure. Journal of Finance, $64,231-261$.

Coles, J. L., Daniel, N. D., \& Naveen, L. (2014). Co-opted boards. Review of Financial Studies, 27, $1751-1796$.

Dalton, D. R., \& Dalton, C. M. (2007). CEO succession: Some finer - and perhaps provocative - points. Journal of Business Strategy, 28, 6-8.

Daniel, N. D., Li, Y., Naveen, L., \& Cornelli, F. (2020). Symmetry in pay for luck. Review of Financial Studies, 33, 3174-3204.

Dasgupta, S., Li, X., \& Wang, A. Y. (2018). Product market competition shocks, firm performance, and forced CEO turnover. Review of Financial Studies, 31, 4187-4231.

Dow, J. (2013). Boards, CEO entrenchment, and the cost of capital. Journal of Financial Economics, $110,680-695$.

Ellis, J., Guo, L., \& Mobbs, S. (2020). How does forced-CEO-turnover experience affect directors? Journal of Financial and Quantitative Analysis, (pp. 1-29).

Ertimur, Y., Ferri, F., \& Maber, D. A. (2012). Reputation penalties for poor monitoring of executive pay: Evidence from option backdating. Journal of Financial Economics, 104, 118-144.

Ertugrul, M., \& Krishnan, K. (2011). Can CEO dismissals be proactive? Journal of Corporate Finance, $17,134-151$.

Fahlenbrach, R., Low, A., \& Stulz, R. M. (2017). Do independent director departures predict future bad events? Review of Financial Studies, 30, 2313-2358.

Falato, A., Kadyrzhanova, D., \& Lel, U. (2014). Distracted directors: Does board busyness hurt shareholder value? Journal of Financial Economics, 113, 404-426.

Faleye, O. (2007). Classified boards, firm value, and managerial entrenchment. Journal of Financial Economics, 83, 501-529.

Fama, E. (1980). Agency problems and the theory of the firm. Journal of Political Economy, 88, 288-307.

Fama, E. F., \& Jensen, M. C. (1983). Separation of ownership and control. The Journal of Law and Economics, 26, 301-325.

Farrell, K. A., \& Whidbee, D. A. (2000). The consequences of forced CEO succession for outside directors. Journal of Business, 73, 597-627. 
Fee, C. E., Hadlock, C. J., Huang, J., \& Pierce, J. R. (2018). Robust models of CEO turnover: New evidence on relative performance evaluation. Review of Corporate Finance Studies, 7, 70-100.

Fee, C. E., Hadlock, C. J., \& Pierce, J. R. (2013). Managers with and without style: Evidence using exogenous variation. Review of Financial Studies, 26, 567-601.

Fich, E. M. (2005). Are some outside directors better than others? Evidence from director appointments by Fortune 1000 firms.

Fischer, P. E., Gramlich, J. D., Miller, B. P., \& White, H. D. (2009). Investor perceptions of board performance: Evidence from uncontested director elections. Journal of Accounting and Economics, 48, 172-189.

Fos, V., Li, K., \& Tsoutsoura, M. (2018). Do director elections matter? Review of Financial Studies, $31,1499-1531$.

Gibson, S., Safieddine, A., \& Sonti, R. (2004). Smart investments by smart money: Evidence from seasoned equity offerings. Journal of Financial Economics, 72, 581-604.

Guo, L., \& Masulis, R. W. (2015). Board structure and monitoring: New evidence from CEO turnovers.

Hambrick, D. C., \& Fukutomi, G. D. (1991). The seasons of a CEO's tenure. Academy of management review. Academy of Management, 16, 719-742.

Henderson, A. D., Miller, D., \& Hambrick, D. C. (2006). How quickly do CEOs become obsolete? Industry dynamism, CEO tenure, and company performance. Strategic Management Journal, 27, $447-460$.

Huson, M. R., Malatesta, P. H., \& Parrino, R. (2004). Managerial succession and firm performance. Journal of Financial Economics, 74, 237-275.

Huson, M. R., Parrino, R., \& Starks, L. T. (2001). Internal monitoring mechanisms and CEO turnover: A long-term perspective.

Jenter, D., \& Kanaan, F. (2015). CEO turnover and relative performance evaluation. Journal of Finance, 70, 2155-2184.

Jenter, D., \& Lewellen, K. (2019). Performance-induced CEO turnover. Working paper. London School of Economics, Tuck School at Dartmouth.

Johnson, W. C., Karpoff, J. M., \& Wittry, M. D. (2019). The consequences to directors of deploying poison pills. Working paper. Suffolk University, University of Washington, Ohio State University. 
Kempf, E., Manconi, A., \& Spalt, O. (2017). Distracted shareholders and corporate actions. Review of Financial Studies, 30, 1660-1695.

Klein, A. (1998). Firm performance and board committee structure. The Journal of Law and Economics, 41, 275-304.

Lechner, M., \& Strittmatter, A. (2019). Practical procedures to deal with common support problems in matching estimation. Econometric Reviews, 38, 193-207.

Levit, D., \& Malenko, N. (2016). The labor market for directors and externalities in corporate governance. Journal of Finance, 71, 775-808.

Marcel, J. J., Cowen, A. P., \& Ballinger, G. A. (2017). Are disruptive CEO successions viewed as a governance lapse? Evidence from board turnover. Journal of Management, 43, 1313-1334.

Masulis, R. W., \& Mobbs, S. (2014). Independent director incentives: Where do talented directors spend their limited time and energy? Journal of Financial Economics, 111, 406-429.

Masulis, R. W., \& Zhang, E. J. (2019). How valuable are independent directors? Evidence from external distractions. Journal of Financial Economics, 132, 226-256.

Matvos, G., \& Ostrovsky, M. (2010). Heterogeneity and peer effects in mutual fund proxy voting. Journal of Financial Economics, 98, 90-112.

Mooney, C. H., Semadeni, M., \& Kesner, I. F. (2017). The selection of an interim CEO: Boundary conditions and the pursuit of temporary leadership. Journal of Management, 43, 455-475.

Nguyen, B. D., \& Nielsen, K. M. (2010). The value of independent directors: Evidence from sudden deaths. Journal of Financial Economics, 98, 550-567.

Parrino, R. (1997). CEO turnover and outside succession A succession analysis. Journal of Financial Economics, 46, 165-197.

Peters, F. S., \& Wagner, A. F. (2014). The executive turnover risk premium. Journal of Finance, 69, $1529-1563$.

Rivolta, M. L. (2018). Worth the wait? Delay in CEO succession after unplanned CEO departures. Journal of Corporate Finance, 49, 225-251.

Ryan, H. E., \& Wiggins, R. A. (2004). Who is in whose pocket? Director compensation, board independence, and barriers to effective monitoring. Journal of Financial Economics, 73, 497-524.

Shivdasani, A. (1993). Board composition, ownership structure, and hostile takeovers. Journal of Accounting and Economics, 16, 167-198. 
Song, F., \& Thakor, A. V. (2006). Information control, career concerns, and corporate governance. Journal of Finance, 61, 1845-1896.

Stein, L. C., \& Zhao, H. (2019). Independent executive directors: How distraction affects their advisory and monitoring roles. Journal of Corporate Finance, 56, 199-223.

Yermack, D. (2004). Remuneration, retention, and reputation incentives for outside directors. Journal of Finance, 59, 2281-2308. 
Figure 1: Changes in withheld re-election votes around an interlocked forced turnover (\%) This figure plots the average within-director changes in withheld votes at a director's re-election around interlocked forced CEO turnovers relative to the average within-director changes in withheld votes at non-turnover-interlocked directors' re-elections at the same point in time. Each bar represents a univariate difference-in-differences estimate between turnoverinterlocked directorships and non-turnover-interlocked directorships for a given re-election date relative to the interlocked forced CEO turnover event. Withheld votes are calculated as the sum of votes withheld and against a director re-election, divided by the total number of votes cast. The sample is based on the intersection of all forced CEO turnovers covered in ISS and BoardEx between January 2003 and December 2017 and includes a total of 607 interlocked director re-elections involving 443 distinct directors at 467 firms, and 87,799 non-turnover-interlocked director re-elections involving 18,684 distinct directors at 3,267 firms. t-statistics are reported in parentheses and are based on standard errors clustered at the industry level. $* * *, * *$, and $*$ denote statistical significance at the $1 \%, 5 \%$, and $10 \%$ level, respectively.

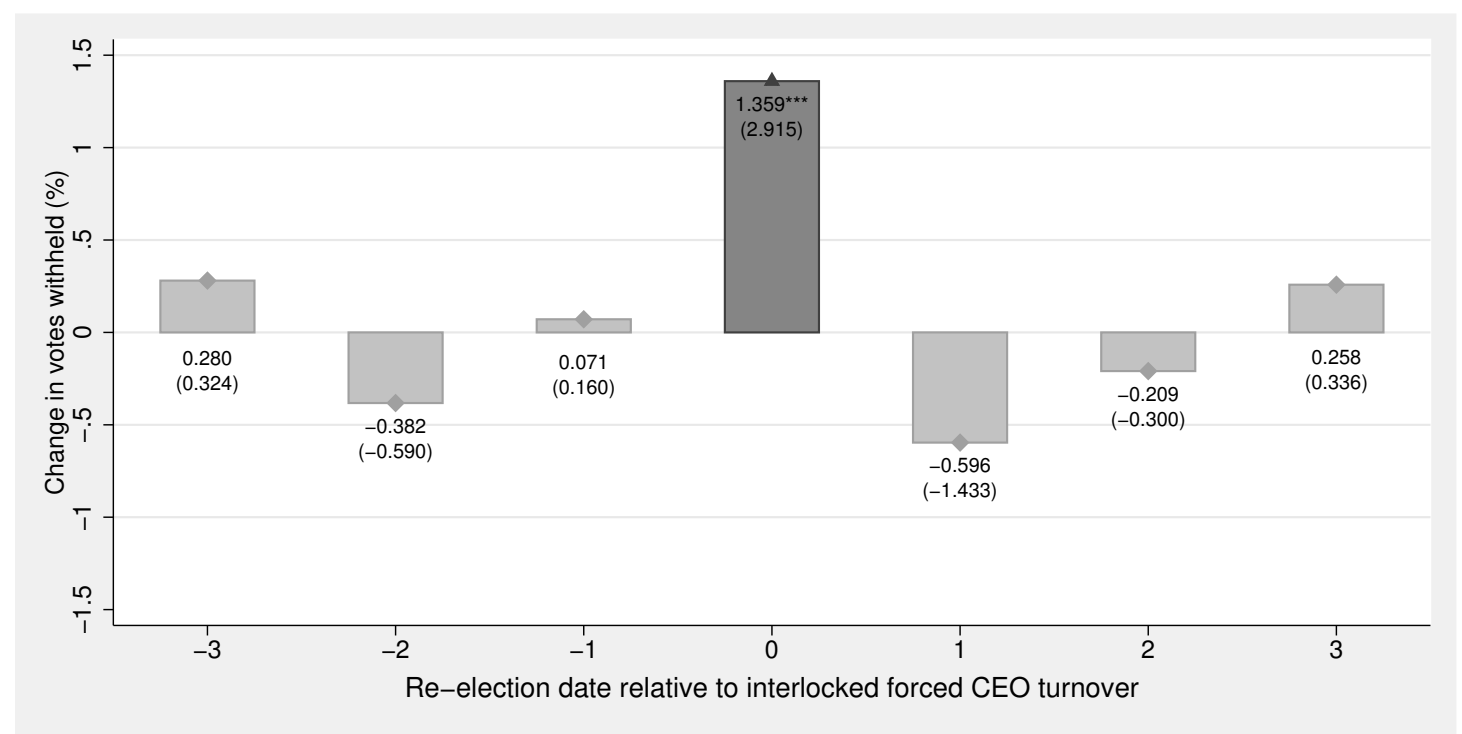


Table 1: Forced CEO turnover and interlocked director characteristics at turnover firms This table reports forced CEO turnover and interlocked director characteristics at the turnover firm. Panel A reports forced turnover characteristics, and Panel B presents interlocked director characteristics at the turnover firm. A CEO turnover is classified as forced if (1) news articles indicate that the CEO is fired, is forced out of her position, or departs due to unspecified policy differences, (2) the CEO does not leave to take over an executive position at another organization, and (3) the CEO leaves the firm within one month after the announced departure date, which includes termination of board membership but does not include remaining consulting positions at the turnover firm. Interlocked directors are directors who serve at the board of a firm that announced a forced departure of a CEO ("turnover firms") as well as at the board of another firm without a CEO turnover ("sample firms"). The sample is based on the intersection of all forced CEO turnovers covered in ISS and BoardEx between January 2003 and December 2017 and includes a total of 206 CEO departures involving 443 distinct directors holding 607 directorships at interlocked firms. Definitions and data sources of all variables are provided in Table B.1 in the Appendix.

Panel A: Forced turnover characteristics

\begin{tabular}{lcccrrr}
\hline & \multicolumn{2}{c}{ Forced turnovers } & & \multicolumn{2}{c}{ Interlocked directorships } \\
\cline { 5 - 6 } \cline { 5 - 6 } & Mean & N & & Mean & N \\
\hline Full replacement announced (d) & 0.451 & 206 & & 0.448 & 607 \\
Performance-induced (d) & 0.881 & 201 & & 0.902 & 591 \\
Honeymoon stage (d) & 0.320 & 206 & & 0.308 & 607 \\
Harvest stage (d) & 0.655 & 206 & & 0.685 & 607 \\
Decline stage (d) & 0.024 & 206 & & 0.012 & 607 \\
\hline
\end{tabular}

Panel B: Interlocked director characteristics at turnover firms

\begin{tabular}{lrr}
\hline & \multicolumn{2}{c}{ Interlocked directorships } \\
\cline { 2 - 3 } & \multicolumn{1}{c}{ Mean } & $\mathrm{N}$ \\
\hline Appointed by turnover CEO (d) & 0.504 & 607 \\
Nominating or compensation committee (d) & 0.796 & 604 \\
\hline
\end{tabular}


Table 2: Interlocked director and firm characteristics

This table reports interlocked director and turnover characteristics. Interlocked directors are directors who serve at the board of a firm that announced a forced departure of a CEO ("turnover firms") as well as at the board of another firm without a CEO turnover ("sample firms"). Panel A reports forced turnover-interlocked director characteristics, Panel B interlocked director characteristics at the interlocked (non-turnover sample firm, and Panel C reports turnover-interlocked sample firm financial and board characteristics. A CEO turnover is classified as forced if (1) news articles indicate that the CEO is fired, is forced out of her position, or departs due to unspecified policy differences, (2) the CEO does not leave to take over an executive position at another organization, and (3) the CEO leaves the firm within one month after the announced departure date, which includes termination of board membership but does not include remaining consulting positions at the turnover firm. The sample is based on the intersection of all forced CEO turnovers covered in ISS and BoardEx between January 2003 and December 2017 and includes a total of 206 CEO departures involving 443 distinct directors holding 607 interlocked board positions. The unit of observation is a director-re-election date-firm triplet. Tobin's Q, ROA, and past buy-and-hold returns are winsorized at the 1st and 99th percentiles. Definitions and data sources of all variables are provided in Table B.1 in the Appendix.

Panel A: Interlocked director characteristics

\begin{tabular}{lrrrr}
\hline & Mean & Median & SD & N \\
\hline Age $(\mathrm{yr})$ & 63.534 & 64.739 & 6.904 & 607 \\
Female $(\mathrm{d})$ & 0.173 & 0.000 & 0.379 & 607 \\
\# of other board seats & 3.142 & 3.000 & 1.918 & 607 \\
\hline
\end{tabular}

Panel B: Interlocked director characteristics at (non-turnover) sample firms

\begin{tabular}{lrrrr}
\hline & Mean & Median & SD & N \\
\hline \% votes withheld & 7.116 & 2.687 & 10.887 & 607 \\
Tenure (yr) & 8.328 & 6.995 & 5.514 & 607 \\
ISS withhold/against (d) & 0.074 & 0.000 & 0.262 & 607 \\
Time between meeting dates (yr) & 1.753 & 1.016 & 0.961 & 607 \\
\hline
\end{tabular}

Panel C: Interlocked sample firm characteristics

\begin{tabular}{lrrrr}
\hline & Mean & Median & SD & N \\
\hline Total assets (millions) & $14,662.478$ & $2,532.490$ & $56,107.593$ & 607 \\
Leverage & 0.247 & 0.217 & 0.213 & 604 \\
Tobin's Q & 2.028 & 1.647 & 1.220 & 607 \\
ROA & 0.138 & 0.133 & 0.110 & 607 \\
BH return (m270,m21) & 0.022 & -0.007 & 0.407 & 607 \\
Board size & 9.778 & 10.000 & 2.180 & 607 \\
\% outside directors & 0.852 & 0.875 & 0.076 & 607 \\
\% busy outside directors & 0.342 & 0.333 & 0.189 & 607 \\
Institutional ownership (\%) & 0.773 & 0.818 & 0.218 & 607 \\
\hline
\end{tabular}


Table 3: Non-turnover-interlocked director and firm characteristics

This table reports non-turnover-interlocked director and firm characteristics. Non-interlocked directors are directors who do not serve on the board of any firm that announces a forced departure of a CEO since her last director re-election. Panel A reports non-turnover-interlocked director characteristics, Panel B non-turnover-interlocked director characteristics at the (non-turnover) sample firm, and Panel C reports non-turnover-interlocked firm characteristics. The sample is based on the intersection of all forced CEO turnovers covered in ISS and BoardEx between January 2003 and December 2017 and includes a total of 87,799 non-turnover-interlocked director re-elections involving 18,684 distinct directors at 3,267 firms. The unit of observation is a director-firm-meeting date triplet. Tobin's Q, ROA, and past buy-and-hold returns are winsorized at the 1st and 99th percentiles. ${ }^{* * *},{ }^{* *}$, and $*$ denote statistical significance of tests for differences between the means and medians of the interlocked and non-turnover-interlocked sample at the $1 \%, 5 \%$, and $10 \%$ level respectively. Definitions and data sources of all variables are provided in Table B.1 in the Appendix.

Panel A: Non-interlocked director characteristics

\begin{tabular}{lrrrr}
\hline & Mean & Median & SD & N \\
\hline Age $(\mathrm{yr})$ & 63.003 & $63.819^{*}$ & 8.707 & 87,786 \\
Female (d) & $0.131^{* * *}$ & $0.000^{* * *}$ & 0.337 & 87,799 \\
\# of other board seats & $1.770^{* * *}$ & $1.000^{* * *}$ & 2.093 & 87,799 \\
\hline
\end{tabular}

Panel B: Non-interlocked director characteristics at (non-turnover) sample firms

\begin{tabular}{lrrrr}
\hline & Mean & Median & SD & N \\
\hline \% votes withheld & $6.139^{* *}$ & $2.458^{* *}$ & 9.623 & 87,799 \\
Tenure (yr) & 8.691 & 6.995 & 6.604 & 87,799 \\
ISS withhold/against (d) & $0.096^{*}$ & $0.000^{*}$ & 0.295 & 87,799 \\
Time between meeting dates (yr) & $1.357^{* * *}$ & $0.997^{* * *}$ & 0.753 & 87,799 \\
\hline
\end{tabular}

Panel C: Non-interlocked sample firm characteristics

\begin{tabular}{lrrrr}
\hline & Mean & Median & SD & $\mathrm{N}$ \\
\hline Total assets (millions) & $10,957.859^{* *}$ & $1,422.700^{* * *}$ & $43,764.939$ & 87,799 \\
Leverage & 0.240 & $0.204^{*}$ & 0.236 & 87,420 \\
Tobin's Q & 2.035 & 1.615 & 1.316 & 87,799 \\
ROA & $0.103^{* * *}$ & $0.128^{* * *}$ & 0.176 & 87,799 \\
BH return (m270,m21) & 0.006 & $-0.046^{* * *}$ & 0.718 & 87,799 \\
Board size & $9.223^{* * *}$ & $9.000^{* * *}$ & 2.359 & 87,799 \\
\% outside directors & $0.836^{* * *}$ & $0.857^{* * *}$ & 0.089 & 87,799 \\
\% busy outside directors & $0.254^{* * *}$ & $0.250^{* * *}$ & 0.193 & 87,799 \\
Institutional ownership (\%) & $0.701^{* * *}$ & $0.794^{* * *}$ & 0.281 & 87,799 \\
\hline
\end{tabular}


Table 4: The effect of forced CEO turnover on interlocked vote shares

This table reports the results of a difference-in-difference regression of the change in the share of withheld votes in re-election on a treatment indicator related to a forced CEO turnover event at an interlocked board appointment of the director and control variables. A CEO turnover is classified as forced if (1) news articles indicate that the CEO is fired, is forced out of her position, or departs due to unspecified policy differences, (2) the CEO does not leave to take over an executive position at another organization, and (3) the CEO leaves the firm within one month after the announced departure date, which includes termination of board membership but does not include remaining consulting positions at the turnover firm. Column 1 reports the baseline regression. Column 2 reports the baseline regression with added interlocked firm fixed effects (FE), and Column 3 reports the baseline regression with added director fixed effects. The unit of observation is a directorfirm-meeting date triplet. All regressions are estimated using ordinary least squares (OLS) in first differences to remove director-firm fixed effects and include year times interlocked firm Fama-French 48 industry fixed effects to remove industry shocks. Withheld votes are calculated as the sum of votes withheld and against a director re-election, divided by the total number of votes cast. Tobin's Q, ROA, and past buy-and-hold returns are winsorized at the 1st and 99th percentiles. The sample is based on the intersection of all forced CEO turnovers covered in ISS and BoardEx between January 2003 and December 2017 and includes a total of 607 interlocked director re-elections involving 443 distinct directors at 467 firms, and 87,799 non-turnover-interlocked director re-elections involving 18,684 distinct directors at 3,267 firms. t-statistics are reported in parentheses and are based on standard errors clustered at the industry level. ***, **, and * denote statistical significance at the $1 \%, 5 \%$, and $10 \%$ level, respectively. See Section 2 for a detailed description of the sample selection process. Definitions and data sources of all variables are provided in Table B.1 in the Appendix.

\begin{tabular}{|c|c|c|c|}
\hline \multirow[t]{2}{*}{ Dependent variable: } & \multicolumn{3}{|c|}{$\%$ votes withheld } \\
\hline & $(1)$ & $(2)$ & $(3)$ \\
\hline Forced interlocked (d) & $\begin{array}{r}1.204^{* * *} \\
(3.071)\end{array}$ & $\begin{array}{r}0.878^{* *} \\
(2.553)\end{array}$ & $\begin{array}{r}1.034^{* *} \\
(2.407)\end{array}$ \\
\hline ISS withhold/against (d) & $\begin{array}{r}18.214^{* * *} \\
(29.462)\end{array}$ & $\begin{array}{r}18.462^{* * *} \\
(29.645)\end{array}$ & $\begin{array}{r}18.644^{* * *} \\
(26.995)\end{array}$ \\
\hline \# of other board seats & $\begin{array}{r}0.128^{* * *} \\
(3.474)\end{array}$ & $\begin{array}{r}0.133^{* * *} \\
(3.100)\end{array}$ & $\begin{array}{r}0.172^{* * *} \\
(3.866)\end{array}$ \\
\hline Board size & $\begin{array}{r}-0.096^{* *} \\
(-2.081)\end{array}$ & $\begin{array}{r}-0.087 \\
(-1.653)\end{array}$ & $\begin{array}{r}-0.103 \\
(-1.632)\end{array}$ \\
\hline$\%$ outside directors & $\begin{array}{r}2.536^{* *} \\
(2.427)\end{array}$ & $\begin{array}{c}2.044^{*} \\
(1.840)\end{array}$ & $\begin{array}{r}2.009 \\
(1.607)\end{array}$ \\
\hline$\%$ busy outside directors & $\begin{array}{r}0.261 \\
(0.614)\end{array}$ & $\begin{array}{r}0.533 \\
(0.987)\end{array}$ & $\begin{array}{r}0.193 \\
(0.354)\end{array}$ \\
\hline Institutional ownership (\%) & $\begin{array}{r}0.049 \\
(0.153)\end{array}$ & $\begin{array}{r}-0.009 \\
(-0.020)\end{array}$ & $\begin{array}{r}0.062 \\
(0.131)\end{array}$ \\
\hline Total assets (millions), log & $\begin{array}{r}0.562^{* * *} \\
(2.940)\end{array}$ & $\begin{array}{c}0.514^{* *} \\
(2.326)\end{array}$ & $\begin{array}{c}0.434^{*} \\
(1.909)\end{array}$ \\
\hline Tobin's Q & $\begin{array}{r}-0.194^{* * *} \\
(-2.827)\end{array}$ & $\begin{array}{c}-0.140^{*} \\
(-1.976)\end{array}$ & $\begin{array}{c}-0.151^{*} \\
(-1.871)\end{array}$ \\
\hline $\mathrm{ROA}$ & $\begin{array}{r}-1.915^{* *} \\
(-2.676)\end{array}$ & $\begin{array}{r}-2.160^{* *} \\
(-2.336)\end{array}$ & $\begin{array}{c}-1.816^{*} \\
(-1.981)\end{array}$ \\
\hline $\mathrm{BH}$ return $(\mathrm{m} 270, \mathrm{~m} 21)$ & $\begin{array}{r}-0.586^{* * *} \\
(-6.892)\end{array}$ & $\begin{array}{r}-0.564^{* * *} \\
(-6.273)\end{array}$ & $\begin{array}{r}-0.596^{* * *} \\
(-6.711)\end{array}$ \\
\hline Year $\times$ Industry FE & Yes & Yes & Yes \\
\hline Firm FE & No & Yes & No \\
\hline Director FE & No & No & Yes \\
\hline Observations & 88,406 & 88,406 & 88,406 \\
\hline Firms & 3,269 & 3,269 & 3,269 \\
\hline Directors & 18,693 & 18,693 & 18,693 \\
\hline Turnover-interlocked directorships & 607 & 607 & 607 \\
\hline Adjusted $R^{2}$ & 0.333 & 0.347 & 0.354 \\
\hline
\end{tabular}


Table 5: Cross-sectional tests: Turnover characteristics and director-level measures

This table reports the results of a difference-in-difference regression of the change in the share of withheld votes in re-election on treatment indicators related to a forced CEO turnover event at an interlocked board appointment of the director and control variables. In Column 1, the treatment indicator is divided between interlocked turnovers at which a full replacement $\mathrm{CEO}$ was appointed and turnovers at which no full replacement CEO was appointed. In Column 2, the treatment indicator is split into performance-induced forced turnovers and not performance-induced turnovers. In Column 3, the treatment indicator is divided into turnovers that happened during the first three years of the CEO's tenure (Forced interlocked during Honeymoon stage $(d)$ ), turnovers at which the CEO was in office for between three and 13 years (Forced interlocked during Harvest stage $(d)$ ), and turnovers at which the CEO was at the helm of the firm for more than 13 years (Forced interlocked during Decline stage $(d)$ ). In Column 4, the treatment indicator is separated into turnover-interlocked directors who are members of the nomination and/or compensation committee of the turnover firm, and interlocked directors who are not members of the nomination and/or compensation committee of the turnover firm. In Column 5, the treatment indicator is divided into interlocked directors who were appointed to the turnover firm's board after the appointment of the CEO (Forced interlocked/co-opted director $(d)$ ) and interlocked directors who were appointed before (Forced interlocked/nonco-opted director $(d))$. The unit of observation is a director-firm-meeting date triplet. All regressions are estimated using ordinary least squares (OLS) in first differences to remove director-firm fixed effects (FE) and include year times interlocked firm Fama-French 48 industry fixed effects to remove industry shocks. Withheld votes are calculated as the sum of votes withheld and against a director re-election, divided by the total number of votes cast. The control variables are as in Table 4 The sample is based on the intersection of all forced CEO turnovers covered in ISS and BoardEx between January 2003 and December 2017 and includes a total of 607 interlocked director re-elections involving 443 distinct directors at 467 firms, and 87,799 non-turnover-interlocked director re-elections involving 18,684 distinct directors at 3,267 firms. t-statistics are reported in parentheses and are based on standard errors clustered at the industry level. ***, **, and * denote statistical significance at the $1 \%, 5 \%$, and $10 \%$ level, respectively. See Section 2 for a detailed description of the sample selection process. Definitions and data sources of all variables are provided in Table B.1 in the Appendix.

\begin{tabular}{|c|c|c|c|c|c|}
\hline \multirow[t]{2}{*}{ Dependent variable: } & \multicolumn{5}{|c|}{$\%$ votes withheld } \\
\hline & $(1)$ & $(2)$ & $(3)$ & $(4)$ & $(5)$ \\
\hline Forced interlocked w. full replacement (d) & $\begin{array}{r}0.837 \\
(1.539)\end{array}$ & & & & \\
\hline Forced interlocked w/o full replacement (d) & $\begin{array}{r}1.507^{* * *} \\
(3.172)\end{array}$ & & & & \\
\hline Forced performance-induced turnover (d) & & $\begin{array}{r}1.415^{* * *} \\
(3.450)\end{array}$ & & & \\
\hline Forced non-performance-induced turnover (d) & & $\begin{array}{r}-0.656 \\
(-0.822)\end{array}$ & & & \\
\hline Forced interlocked during Honeymoon stage (d) & & & $\begin{array}{r}0.197 \\
(0.314)\end{array}$ & & \\
\hline Forced interlocked during Harvest stage (d) & & & $\begin{array}{r}1.679 * * * \\
(4.288)\end{array}$ & & \\
\hline Forced interlocked during Decline stage (d) & & & $\begin{array}{r}-0.121 \\
(-0.049)\end{array}$ & & \\
\hline Forced interlocked/committee member (d) & & & & $\begin{array}{r}1.566^{* * *} \\
(3.748)\end{array}$ & \\
\hline Forced interlocked/not committee member (d) & & & & $\begin{array}{r}-0.246 \\
(-0.348)\end{array}$ & \\
\hline Forced interlocked/co-opted director (d) & & & & & $\begin{array}{r}1.670^{* * *} \\
(3.373)\end{array}$ \\
\hline Forced interlocked/non-co-opted director (d) & & & & & $\begin{array}{r}0.720 \\
(1.566)\end{array}$ \\
\hline Control variables & Yes & Yes & Yes & Yes & Yes \\
\hline Year $\times$ Industry FE & Yes & Yes & Yes & Yes & Yes \\
\hline Observations & 88,406 & 88,390 & 88,406 & 88,403 & 88,406 \\
\hline Firms & 3,269 & 3,269 & 3,269 & 3,269 & 3,269 \\
\hline Directors & 18,693 & 18,693 & 18,693 & 18,693 & 18,693 \\
\hline Turnover-interlocked directorships & 607 & 591 & 607 & 604 & 607 \\
\hline Adjusted $R^{2}$ & 0.333 & 0.333 & 0.334 & 0.334 & 0.333 \\
\hline
\end{tabular}


Table 6: Cross-sectional tests: Common ownership within turnover and interlocked firms This table reports the results of a difference-in-difference regression of the change in the share of withheld votes in re-election on treatment indicators related to a forced CEO turnover event at an interlocked board appointment of the director and control variables. In Column 1, the treatment indicator is divided between one indicating involvement into a forced CEO departure with common ownership between the turnover and the interlocked firm above mean common ownership (Forced interlocked $\geq$ mean common own $(d)$ ) and one with common ownership below its sample mean (Forced interlocked $<$ mean common own. $(d)$ ). In Column 2 , the treatment indicator is split into one indicating involvement into a forced CEO departure with common ownership between the turnover and the interlocked firm above median common ownership (Forced interlocked $\geq$ median common own $(d)$ ) and one with common ownership below its sample median (Forced interlocked $<$ median common own. $(d)$ ). The unit of observation is a director-firm-meeting date triplet. All regressions are estimated using ordinary least squares (OLS) in first differences to remove director-firm fixed effects (FE) and include year times interlocked firm Fama-French 48 industry fixed effects to remove industry shocks. Withheld votes are calculated as the sum of votes withheld and against a director re-election, divided by the total number of votes cast. The control variables are as in Table 4 . The sample is based on the intersection of all forced CEO turnovers covered in ISS and BoardEx between January 2003 and December 2017 and includes a total of 591 interlocked director re-elections involving 430 distinct directors at 459 firms, and 87,799 non-turnover-interlocked director re-elections involving 18,684 distinct directors at 3,267 firms. t-statistics are reported in parentheses and are based on standard errors clustered at the industry level. ***, **, and * denote statistical significance at the $1 \%, 5 \%$, and $10 \%$ level, respectively. See Section 2 for a detailed description of the sample selection process. Definitions and data sources of all variables are provided in Table B.1 in the Appendix.

\begin{tabular}{lrr}
\hline Dependent variable: & \% votes withheld \\
\cline { 2 - 3 } Forced interlocked $\geq$ mean common own. (d) & $1.442^{* *}$ \\
& $(2.678)$ \\
Forced interlocked $<$ mean common own. (d) & 0.900 \\
& $(1.670)$ \\
Forced interlocked $\geq$ median common own. (d) & $1.513^{* *}$ \\
Forced interlocked $<$ median common own. (d) & $(2.603)$ \\
& $0.870^{*}$ \\
Control variables & $(1.758)$ \\
Year $\times$ Industry FE & Yes & Yes \\
Observations & Yes & Yes \\
Firms & 88,390 \\
Directors & 38,269 \\
Turnover-interlocked directorships & 390 \\
Adjusted $R^{2}$ & 18,693 & 18,693 \\
\hline
\end{tabular}


Table 7: Forced CEO turnover and director distraction

This table reports the results of a difference-in-difference regression of the change in the share of withheld votes in reelection on treatment indicators related to either a forced CEO turnover event or an exogenous workload shock at an interlocked board appointment of the director and control variables. In Column 1, the workload shock is the unexpected death of the CEO (Death interlocked $(d)$ ). In Column 2, the sample of unexpected deaths is extended by unexpected CEO sick leaves, during which the CEO subsequently dies (Death interlocked (extended) (d)). In Column 3, the exogenous attention shock is the workload increase from sharing a committee membership with a forced CEO turnover-interlocked director (Committee-interlocked $(d)$ ). The unit of observation is a director-firm-meeting date triplet. All regressions are estimated using ordinary least squares (OLS) in first differences to remove director-firm fixed effects (FE) and includes year times interlocked firm Fama-French 48 industry fixed effects to remove industry shocks. Withheld votes are calculated as the sum of votes withheld and against a director re-election, divided by the total number of votes cast. The control variables are as in Table 4 The sample is based on the intersection of all forced CEO turnovers covered in ISS and BoardEx between January 2003 and December 2017 and includes a total of 607 interlocked director re-elections involving 443 distinct directors at 467 firms, and 87,799 non-turnover-interlocked director re-elections involving 18,684 distinct directors at 3,267 firms. t-statistics are reported in parentheses and are based on standard errors clustered at the industry level. $* * *$, $* *$, and $*$ denote statistical significance at the $1 \%, 5 \%$, and $10 \%$ level, respectively. See Section 2 for a detailed description of the sample selection process. Definitions and data sources of all variables are provided in Table B.1]in the Appendix.

\begin{tabular}{|c|c|c|c|}
\hline \multirow[t]{2}{*}{ Dependent variable: } & \multicolumn{3}{|c|}{$\%$ votes withheld } \\
\hline & $(1)$ & $(2)$ & $(3)$ \\
\hline Forced interlocked $(\mathrm{d})$ & $\begin{array}{r}1.211^{* * *} \\
(3.070)\end{array}$ & $\begin{array}{r}1.209^{* * *} \\
(3.067)\end{array}$ & $\begin{array}{r}1.223^{* * *} \\
(3.012)\end{array}$ \\
\hline Death interlocked $(\mathrm{d})$ & $\begin{array}{r}-0.586 \\
(-1.005)\end{array}$ & & \\
\hline Death interlocked (extended) (d) & & $\begin{array}{r}0.768 \\
(0.870)\end{array}$ & \\
\hline Committee-interlocked (d) & & & $\begin{array}{r}0.495 \\
(1.495)\end{array}$ \\
\hline Control variables & Yes & Yes & Yes \\
\hline Year $\times$ Industry FE & Yes & Yes & Yes \\
\hline Observations & 88,372 & 88,363 & 85,778 \\
\hline Firms & 3,269 & 3,269 & 3,256 \\
\hline Directors & 18,692 & 18,692 & 18,036 \\
\hline Turnover-interlocked directorships & 605 & 605 & 600 \\
\hline Death/Committee-interlocked directorships & 28 & 39 & 1,628 \\
\hline Adjusted $R^{2}$ & 0.333 & 0.333 & 0.338 \\
\hline
\end{tabular}


Table 8: Testing for reversal and pseudo treatments

This table reports the results of a difference-in-difference regression of the change in the share of withheld votes in re-election on treatment indicators related to a forced CEO turnover event at an interlocked board appointment of the director and control variables. Column 1 additionally includes a lagged treatment indicator. Column 2 includes a first and second lagged treatment indicators. Columns 3 and 4 report the results of the baseline model but with pseudo treatment dates, which are one and two re-election dates before the actual treatment, respectively. The unit of observation is a director-firm-meeting date triplet. All regressions are estimated using ordinary least squares (OLS) in first differences to remove director-firm fixed effects (FE) and include year times interlocked firm Fama-French 48 industry fixed effects to remove industry shocks. Withheld votes are calculated as the sum of votes withheld and against a director re-election, divided by the total number of votes cast. The control variables are as in Table 4 . The sample is based on the intersection of all forced CEO turnovers covered in ISS and BoardEx between January 2003 and December 2017 and includes a total of 607 interlocked director re-elections involving 443 distinct directors at 467 firms, and 87,799 non-turnover-interlocked director re-elections involving 18,684 distinct directors at 3,267 firms. t-statistics are reported in parentheses and are based on standard errors clustered at the industry level. ***,**, and * denote statistical significance at the $1 \%, 5 \%$, and $10 \%$ level, respectively. See Section 2 for a detailed description of the sample selection process. Definitions and data sources of all variables are provided in Table B.1 in the Appendix.

\begin{tabular}{|c|c|c|c|c|}
\hline \multirow[t]{2}{*}{ Dependent variable: } & \multicolumn{4}{|c|}{$\%$ votes withheld } \\
\hline & $\begin{array}{c}(1) \\
\text { Baseline plus lag }\end{array}$ & $\begin{array}{c}(2) \\
\text { Baseline plus lags }\end{array}$ & $\begin{array}{c}(3) \\
\text { Pseudo at t-1 }\end{array}$ & $\begin{array}{c}\text { (4) } \\
\text { Pseudo at t-2 }\end{array}$ \\
\hline Forced interlocked (d) & $\begin{array}{r}1.202^{* * *} \\
(3.052)\end{array}$ & $\begin{array}{r}1.279^{* * *} \\
(2.863)\end{array}$ & $\begin{array}{r}0.020 \\
(0.054)\end{array}$ & $\begin{array}{r}-0.390 \\
(-0.835)\end{array}$ \\
\hline Forced interlocked at t-1 (d) & $\begin{array}{r}0.097 \\
(0.272)\end{array}$ & $\begin{array}{r}0.373 \\
(1.066)\end{array}$ & & \\
\hline Forced interlocked at t-2 (d) & & $\begin{array}{r}-0.325 \\
(-0.506)\end{array}$ & & \\
\hline Control variables & Yes & Yes & Yes & Yes \\
\hline Year $\times$ Industry FE & Yes & Yes & Yes & Yes \\
\hline Observations & 88,406 & 64,555 & 64,450 & 47,544 \\
\hline Firms & 3,269 & 2,582 & 2,577 & 2,098 \\
\hline Directors & 18,693 & 13,817 & 13,788 & 10,588 \\
\hline Turnover-interlocked directorships & 607 & 424 & 420 & 315 \\
\hline Adjusted $R^{2}$ & 0.333 & 0.360 & 0.418 & 0.431 \\
\hline
\end{tabular}


Table 9: Propensity score matching analysis on turnover-interlocking

This table reports the results of a regression of the fraction of withheld votes at the re-election of a director on treatment indicators related to a forced CEO turnover event at an interlocked board appointment of the director and control variables. Columns 1 and 4 report the baseline regressions. Column 2 and 5 additionally include year and industry fixed effects (FE) to remove time-trends and industry-specific differences, and Columns 3 and 6 include turnover event fixed effects to remove unobservables from the individual turnover events. The unit of observation is a director-firm-meeting date triplet. All regressions are estimated using ordinary least squares (OLS). Withheld votes are calculated as the sum of votes withheld and against a director re-election, divided by the total number of votes cast. Tobin's Q, ROA, and past buy-and-hold returns are winsorized at the 1st and 99th percentiles. The sample consists of re-elections of outside directors who were interlocked to forced CEO turnovers at S\&P 1500 firms between January 2003 and December 2017 (Forced interlocked $(d)==1$ ) or to propensity score-matched firms (Forced interlocked $(d)==0$ ). The propensity score model used in Columns 1-3 is based on the forced turnover likelihood model introduced by Peters \& Wagner (2014). The sample includes 525 forced turnover-interlocked director re-elections and 586 matched firm-interlocked director re-elections and covers 181 distinct forced CEO turnovers. In Columns 4-6, we estimate the propensity scores with an extended model, in which we add the mean change in re-election votes of all board members prior to the matching date to the turnover likelihood model by Peters \& Wagner (2014). The sample includes 439 forced turnover-interlocked director re-elections and 495 matched firm-interlocked director re-elections and covers 147 distinct forced CEO turnovers. t-statistics are reported in parentheses and are based on standard errors clustered either at the industry level (Columns 1 and 2) or at the turnover event level (Column 3). ${ }^{* * *}, * *$, and $*$ denote statistical significance at the 1\%, 5\%, and $10 \%$ level, respectively. See Section 4.2 for a detailed description of the sample selection process. Definitions and data sources of all variables are provided in Table B.1 in the Appendix.

\begin{tabular}{|c|c|c|c|c|c|c|}
\hline \multirow[t]{2}{*}{ Dependent variable: } & \multicolumn{6}{|c|}{$\%$ votes withheld } \\
\hline & $(1)$ & $(2)$ & (3) & $(4)$ & $(5)$ & $(6)$ \\
\hline Forced interlocked (d) & $\begin{array}{r}1.439^{* *} \\
(2.687)\end{array}$ & $\begin{array}{r}1.436 * * * \\
(2.961)\end{array}$ & $\begin{array}{c}1.010^{*} \\
(1.834)\end{array}$ & $\begin{array}{r}1.485^{* *} \\
(2.592)\end{array}$ & $\begin{array}{c}1.252^{* *} \\
(2.232)\end{array}$ & $\begin{array}{r}0.971^{*} \\
(1.821)\end{array}$ \\
\hline ISS withhold/against (d) & $\begin{array}{r}19.504^{* * *} \\
(10.423)\end{array}$ & $\begin{array}{r}19.321^{* * *} \\
(10.077)\end{array}$ & $\begin{array}{r}19.688 * * * \\
(10.231)\end{array}$ & $\begin{array}{r}21.802^{* * *} \\
(11.626)\end{array}$ & $\begin{array}{r}22.310^{* * *} \\
(11.365)\end{array}$ & $\begin{array}{r}22.162^{* * *} \\
(14.797)\end{array}$ \\
\hline Female (d) & $\begin{array}{r}-0.480 \\
(-0.707)\end{array}$ & $\begin{array}{r}-0.329 \\
(-0.499)\end{array}$ & $\begin{array}{r}-0.379 \\
(-0.701)\end{array}$ & $\begin{array}{r}-1.050 \\
(-1.295)\end{array}$ & $\begin{array}{r}-0.556 \\
(-0.644)\end{array}$ & $\begin{array}{r}-0.586 \\
(-0.985)\end{array}$ \\
\hline Age (yr) & $\begin{array}{r}-0.016 \\
(-0.354)\end{array}$ & $\begin{array}{r}-0.037 \\
(-0.791)\end{array}$ & $\begin{array}{r}-0.039 \\
(-1.017)\end{array}$ & $\begin{array}{r}0.045 \\
(1.205)\end{array}$ & $\begin{array}{r}0.044 \\
(1.078)\end{array}$ & $\begin{array}{r}0.022 \\
(0.481)\end{array}$ \\
\hline Tenure (yr), log & $\begin{array}{r}1.507^{* * *} \\
(4.040)\end{array}$ & $\begin{array}{r}1.323^{* * *} \\
(3.817)\end{array}$ & $\begin{array}{r}1.809 * * * \\
(5.295)\end{array}$ & $\begin{array}{r}1.215^{* * *} \\
(2.806)\end{array}$ & $\begin{array}{r}1.165^{* * *} \\
(2.926)\end{array}$ & $\begin{array}{r}1.099 * * * \\
(2.821)\end{array}$ \\
\hline \# of other board seats & $\begin{array}{r}-0.034 \\
(-0.217)\end{array}$ & $\begin{array}{r}0.045 \\
(0.364)\end{array}$ & $\begin{array}{r}0.039 \\
(0.220)\end{array}$ & $\begin{array}{r}0.265^{* *} \\
(2.442)\end{array}$ & $\begin{array}{r}0.325^{* * *} \\
(3.057)\end{array}$ & $\begin{array}{r}0.275^{* *} \\
(2.091)\end{array}$ \\
\hline Board size & $\begin{array}{r}-0.114 \\
(-0.785)\end{array}$ & $\begin{array}{r}-0.043 \\
(-0.331)\end{array}$ & $\begin{array}{r}-0.134 \\
(-0.832)\end{array}$ & $\begin{array}{r}-0.325^{* *} \\
(-2.407)\end{array}$ & $\begin{array}{r}-0.192 \\
(-1.404)\end{array}$ & $\begin{array}{r}-0.300 \\
(-1.602)\end{array}$ \\
\hline$\%$ outside directors & $\begin{array}{c}6.814^{*} \\
(1.690)\end{array}$ & $\begin{array}{r}-0.419 \\
(-0.093)\end{array}$ & $\begin{array}{r}4.519 \\
(1.227)\end{array}$ & $\begin{array}{r}6.973 \\
(1.148)\end{array}$ & $\begin{array}{r}3.399 \\
(0.567)\end{array}$ & $\begin{array}{r}1.549 \\
(0.342)\end{array}$ \\
\hline$\%$ busy outside directors & $\begin{array}{r}-0.001 \\
(-0.000)\end{array}$ & $\begin{array}{r}0.315 \\
(0.257)\end{array}$ & $\begin{array}{r}0.663 \\
(0.438)\end{array}$ & $\begin{array}{r}0.740 \\
(0.479)\end{array}$ & $\begin{array}{r}0.923 \\
(0.635)\end{array}$ & $\begin{array}{r}0.340 \\
(0.221)\end{array}$ \\
\hline Institutional ownership (\%) & $\begin{array}{r}0.560 \\
(0.486)\end{array}$ & $\begin{array}{r}0.141 \\
(0.129)\end{array}$ & $\begin{array}{r}-0.501 \\
(-0.480)\end{array}$ & $\begin{array}{r}0.200 \\
(0.177)\end{array}$ & $\begin{array}{r}-0.357 \\
(-0.285)\end{array}$ & $\begin{array}{r}-0.533 \\
(-0.497)\end{array}$ \\
\hline Total assets (millions), log & $\begin{array}{r}0.140 \\
(0.551)\end{array}$ & $\begin{array}{r}0.370 \\
(1.347)\end{array}$ & $\begin{array}{r}0.011 \\
(0.043)\end{array}$ & $\begin{array}{c}0.531^{*} \\
(1.758)\end{array}$ & $\begin{array}{c}0.528^{*} \\
(1.868)\end{array}$ & $\begin{array}{r}0.411 \\
(1.516)\end{array}$ \\
\hline Tobin's Q & $\begin{array}{r}0.043 \\
(0.180)\end{array}$ & $\begin{array}{r}0.161 \\
(0.673)\end{array}$ & $\begin{array}{r}0.053 \\
(0.249)\end{array}$ & $\begin{array}{r}0.183 \\
(1.120)\end{array}$ & $\begin{array}{c}0.322^{*} \\
(1.929)\end{array}$ & $\begin{array}{r}0.149 \\
(0.637)\end{array}$ \\
\hline $\mathrm{ROA}$ & $\begin{array}{r}-2.518 \\
(-0.963)\end{array}$ & $\begin{array}{r}-4.135^{* *} \\
(-2.142)\end{array}$ & $\begin{array}{r}-1.373 \\
(-0.676)\end{array}$ & $\begin{array}{r}-2.533 \\
(-0.954)\end{array}$ & $\begin{array}{c}-3.623^{*} \\
(-1.701)\end{array}$ & $\begin{array}{r}-1.456 \\
(-0.744)\end{array}$ \\
\hline BH return $(\mathrm{m} 270, \mathrm{~m} 21)$ & $\begin{array}{r}-1.944 * * * \\
(-3.122)\end{array}$ & $\begin{array}{r}-1.628^{* * *} \\
(-2.928)\end{array}$ & $\begin{array}{r}-2.012^{* * *} \\
(-3.198)\end{array}$ & $\begin{array}{r}-3.154^{* * *} \\
(-4.363)\end{array}$ & $\begin{array}{r}-3.261^{* * *} \\
(-3.906)\end{array}$ & $\begin{array}{r}-3.667^{* * *} \\
(-4.579)\end{array}$ \\
\hline Year FE & No & Yes & No & No & Yes & No \\
\hline Industry FE & No & Yes & No & No & Yes & No \\
\hline Turnover FE & No & $\mathrm{No}$ & Yes & No & No & Yes \\
\hline Observations & 1,111 & 1,111 & 1,111 & 934 & 934 & 934 \\
\hline Firms & 745 & 745 & 745 & 646 & 646 & 646 \\
\hline Directors & 762 & 762 & 762 & 619 & 619 & 619 \\
\hline Turnover-interlocked d'ships & 525 & 525 & 525 & 439 & 439 & 439 \\
\hline Adjusted $R^{2}$ & 0.284 & 0.303 & 0.305 & 0.351 & 0.372 & 0.393 \\
\hline
\end{tabular}


Table 10: The effect of forced CEO turnover on losses of directorships

This table reports the results of linear regression models analyzing the effect of a forced CEO turnover on the number of directorships. The sample consists of 594 (Columns 1 and 2) and 489 (Columns 3 and 4) outside directorships of directors who are interlocked to forced CEO turnovers at S\&P 1500 firms between January 2003 and December 2017 (Forced interlocked $(d)==1$ ), and 3,419 resp. 2,811 outside directorships of directors who are not interlocked to a forced turnover themselves but share a board seat with an interlocked director at the interlocked firm during the time of the interlocked forced turnover (Forced interlocked $(d)==0$ ). The outcome variable (Loses directorships within $t$ years $(d)$ ) is an indicator variable set equal to one if a director loses any of her outside directorships within $t$ years following the interlocked forced CEO turnover. In Columns 1 and 2, the outcome variable is measured over a period of 1 year, and in Columns 3 and 4 over a period of five years. All Columns include turnover event fixed effects (FE) to remove unobservables from the individual turnover events. Columns 2 and 4 additionally include interlocked firm fixed effects to control for interlocked-firm specific characteristics. All regressions are estimated using ordinary least squares (OLS). t-statistics are reported in parentheses and are based on standard errors clustered at the turnover-event level. ***, **, and * denote statistical significance at the $1 \%, 5 \%$, and $10 \%$ level, respectively. Definitions and data sources of all variables are provided in Table B.1 in the Appendix.

\begin{tabular}{lrrrr}
\hline Dependent variable: & \multicolumn{3}{c}{ Loses directorships within $\mathrm{t}$ years $(\mathrm{d})$} \\
\cline { 2 - 5 } & \multicolumn{1}{c}{$(1)$} & \multicolumn{1}{c}{$(2)$} & \multicolumn{1}{c}{$(3)$} & $(4)$ \\
& $\mathrm{t}=[0,1]$ & $\mathrm{t}=[0,1]$ & $\mathrm{t}=[0,5]$ & $\mathrm{t}=[0,5]$ \\
\hline Forced interlocked $(\mathrm{d})$ & $0.072^{* * *}$ & $0.075^{* * *}$ & $0.088^{* *}$ & $0.097^{* * *}$ \\
& $(2.979)$ & $(2.919)$ & $(2.595)$ & $(2.706)$ \\
Director age $(\mathrm{yr})$ & -0.000 & 0.000 & $0.009^{* * *}$ & $0.009^{* * *}$ \\
& $(-0.217)$ & $(0.328)$ & $(6.832)$ & $(6.021)$ \\
Female (d) & -0.008 & -0.018 & $0.039^{*}$ & 0.027 \\
& $(-0.535)$ & $(-1.102)$ & $(1.722)$ & $(1.098)$ \\
\# of other board seats & $0.031^{* * *}$ & $0.028^{* * *}$ & $0.046^{* * *}$ & $0.043^{* * *}$ \\
& $(4.760)$ & $(4.052)$ & $(4.391)$ & $(3.703)$ \\
Tenure (yr), log & -0.000 & 0.000 & $0.025^{*}$ & $0.045^{* * *}$ \\
& $(-0.048)$ & $(0.045)$ & $(1.888)$ & $(2.810)$ \\
Turnover FE & Yes & Yes & Yes & Yes \\
Firm FE & No & Yes & No & Yes \\
\hline Observations & 4,013 & 4,013 & 3,300 & 3,300 \\
Firms & 465 & 465 & 404 & 404 \\
Directors & 2,885 & 2,885 & 2,425 & 2,425 \\
Turnover-interlocked directorships & 594 & 594 & 489 & 489 \\
Adjusted $R^{2}$ & 0.061 & 0.055 & 0.093 & 0.092 \\
\hline
\end{tabular}


Table 11: The effect of forced CEO turnover on gains and losses of directorships

This table reports the results of linear regression models analyzing the effect of a forced CEO turnover on gains and losses of directorships. The sample consists of 594 (Columns 1 and 2) and 489 (Columns 3 and 4) outside directorships of directors who are interlocked to forced CEO turnovers at S\&P 1500 firms between January 2003 and December 2017 (Forced interlocked $(d)==1$ ), and 3,419 resp. 2,811 outside directorships of directors who are not interlocked to a forced turnover themselves but share a board seat with an interlocked director at the interlocked firm during the time of the interlocked forced turnover (Forced interlocked $(d)==0$ ). The outcome variable in Panel A (Loses directorships within $t$ years $(d)$ ) is an indicator variable set equal to one if a director loses any of her outside directorships within t years following the interlocked forced CEO turnover, ignoring directorships at the turnover firm. The outcome variable in Panel B (Gains directorships within $t$ years $(d)$ ) is an indicator variable set equal to one if a director obtains a new outside directorship within t years following the interlocked forced CEO turnover. The outcome variable in Panel C (Net loss of directorships within $t$ years $(d))$ is an indicator variable set equal to one if a director loses more outside directorships than she gains new ones within $\mathrm{t}$ years following the interlocked forced CEO turnover. In Columns 1 and 2 of all panels, the outcome variable is measured over a period of 1 year, and in Columns 3 and 4 over a period of five years. All Columns include control variables controlling for director age, gender, the number of other outside board seats at the turnover date, and the natural logarithm of tenure at the interlocked firm. Additionally, all Columns include turnover event fixed effects (FE) to remove unobservables from the individual turnover events. Columns 2 and 4 additionally include interlocked firm fixed effects to control for interlocked-firm specific characteristics. All regressions are estimated using ordinary least squares (OLS). t-statistics are reported in parentheses and are based on standard errors clustered at the turnover-event level. ***, $* *$, and $*$ denote statistical significance at the $1 \%, 5 \%$, and $10 \%$ level, respectively. Definitions and data sources of all variables are provided in Table B.1 in the Appendix.

Panel A: Director turnover likelihood (w/o turnover firm)

\begin{tabular}{|c|c|c|c|c|}
\hline \multirow[t]{3}{*}{ Dependent variable: } & \multicolumn{4}{|c|}{ Loses directorships within t years $(\mathrm{d})$} \\
\hline & (1) & $(2)$ & (3) & $(4)$ \\
\hline & $\mathrm{t}=[0,1]$ & $\mathrm{t}=[0,1]$ & $\mathrm{t}=[0,5]$ & $\mathrm{t}=[0,5]$ \\
\hline \multirow[t]{2}{*}{ Forced interlocked (d) } & -0.002 & -0.000 & -0.024 & -0.016 \\
\hline & $(-0.088)$ & $(-0.018)$ & $(-0.767)$ & $(-0.489)$ \\
\hline Director control variables & Yes & Yes & Yes & Yes \\
\hline Turnover FE & Yes & Yes & Yes & Yes \\
\hline Firm FE & No & Yes & No & Yes \\
\hline Observations & 4,013 & 4,013 & 3,300 & 3,300 \\
\hline Firms & 465 & 465 & 404 & 404 \\
\hline Directors & 2,885 & 2,885 & 2,425 & 2,425 \\
\hline Turnover-interlocked directorships & 594 & 594 & 489 & 489 \\
\hline Adjusted $R^{2}$ & 0.054 & 0.046 & 0.086 & 0.084 \\
\hline
\end{tabular}

Panel B: The likelihood of new directorships

\begin{tabular}{|c|c|c|c|c|}
\hline \multirow[t]{2}{*}{ Dependent variable: } & \multicolumn{4}{|c|}{ Gains directorships within t years $(\mathrm{d})$} \\
\hline & $\begin{array}{c}(1) \\
\mathrm{t}=[0,1]\end{array}$ & $\begin{array}{c}(2) \\
\mathrm{t}=[0,1]\end{array}$ & $\begin{array}{c}(3) \\
\mathrm{t}=[0,5]\end{array}$ & $\begin{array}{c}(4) \\
\mathrm{t}=[0,5]\end{array}$ \\
\hline Forced interlocked (d) & $\begin{array}{r}0.017 \\
(0.793)\end{array}$ & $\begin{array}{r}0.018 \\
(0.777)\end{array}$ & $\begin{array}{r}0.080^{* * *} \\
(2.929)\end{array}$ & $\begin{array}{r}0.087^{* * *} \\
(2.942)\end{array}$ \\
\hline Director control variables & Yes & Yes & Yes & Yes \\
\hline Turnover FE & Yes & Yes & Yes & Yes \\
\hline Firm FE & No & Yes & No & Yes \\
\hline Observations & 4,013 & 4,013 & 3,300 & 3,300 \\
\hline Firms & 465 & 465 & 404 & 404 \\
\hline Directors & 2,885 & 2,885 & 2,425 & 2,425 \\
\hline Turnover-interlocked directorships & 594 & 594 & 489 & 489 \\
\hline Adjusted $R^{2}$ & 0.021 & 0.017 & 0.089 & 0.087 \\
\hline
\end{tabular}


Table 11: The effect of forced CEO turnover on gains and losses of directorships (cont.)

Panel C: The likelihood of a net loss of board seats

\begin{tabular}{|c|c|c|c|c|}
\hline \multirow[t]{2}{*}{ Dependent variable: } & \multicolumn{4}{|c|}{ Net loss of directorships within t years $(d)$} \\
\hline & $\begin{array}{c}(1) \\
\mathrm{t}=[0,1]\end{array}$ & $\begin{array}{c}(2) \\
\mathrm{t}=[0,1]\end{array}$ & $\begin{array}{c}(3) \\
\mathrm{t}=[0,5]\end{array}$ & $\begin{array}{c}(4) \\
\mathrm{t}=[0,5]\end{array}$ \\
\hline Forced interlocked (d) & $\begin{array}{r}0.067^{* * * *} \\
(3.038)\end{array}$ & $\begin{array}{r}0.068^{* * *} \\
(2.870)\end{array}$ & $\begin{array}{r}0.031 \\
(1.098)\end{array}$ & $\begin{array}{r}0.033 \\
(1.103)\end{array}$ \\
\hline Control variables & Yes & Yes & Yes & Yes \\
\hline Turnover FE & Yes & Yes & Yes & Yes \\
\hline Firm FE & No & Yes & No & Yes \\
\hline Observations & 4,013 & 4,013 & 3,300 & 3,300 \\
\hline Firms & 465 & 465 & 404 & 404 \\
\hline Directors & 2,885 & 2,885 & 2,425 & 2,425 \\
\hline Turnover-interlocked directorships & 594 & 594 & 489 & 489 \\
\hline Adjusted $R^{2}$ & 0.046 & 0.042 & 0.083 & 0.092 \\
\hline
\end{tabular}


Table 12: The effect of CEO forced turnover on the cumulative asset size of all board seats This table reports the results of linear regression models analyzing the effect of a forced CEO turnover on the change of the cumulative asset size of a director's board seats. The sample consists of 594 (Columns 1 and 2) and 489 (Columns 3 and 4) outside directorships of directors who are interlocked to forced CEO turnovers at S\&P 1500 firms between January 2003 and December 2017 (Forced interlocked $(d)==1$ ), and 3,419 resp. 2,811 outside directorships of directors who are not interlocked to a forced turnover themselves but share a board seat with an interlocked director at the interlocked firm during the time of the interlocked forced turnover (Forced interlocked $(d)==0$ ). The outcome variable in Panel A (Difference in the sum of total assets over all directorships (millions)) is the hyperbolic sine transformed difference between the sum of total assets of all firms at which a director holds an outside directorship at year $t$ following the interlocked forced CEO turnover, and the sum of total assets of all firms at which a director holds an outside directorship at the year of the interlocked turnover. The outcome variable in Panel B (Difference in the sum of total assets over all directorships (millions)) is measured identically to the outcome in Panel A except that it excludes the total assets of the turnover firm. In Columns 1 and 2 of both panels, year $t$ is defined as one year following the interlocked forced CEO turnover, in Columns 3 and 4 as five years. All Columns include control variables controlling for director age, gender, the number of other outside board seats at the turnover date, and the natural logarithm of tenure at the interlocked firm. Additionally, all Columns include turnover event fixed effects (FE) to remove unobservables from the individual turnover events. Columns 3 and 4 additionally include interlocked firm fixed effects to control for interlocked-firm specific characteristics. All regressions are estimated using ordinary least squares (OLS). t-statistics are reported in parentheses and are based on standard errors clustered at the turnover-event level. ${ }^{* * *}, * *$, and * denote statistical significance at the $1 \%, 5 \%$, and $10 \%$ level, respectively. Definitions and data sources of all variables are provided in Table B.1 in the Appendix.

Panel A: The change in the sum of total assets of all board seats

\begin{tabular}{lcrrr}
\hline Dependent variable: & \multicolumn{2}{c}{ Difference in the sum of total assets over all directorships (millions) } \\
\cline { 2 - 5 } & $(1)$ & $(2)$ & $(3)$ & $(4)$ \\
& $t_{1}-t_{0}$ & $t_{1}-t_{0}$ & $t_{5}-t_{0}$ & $t_{5}-t_{0}$ \\
\hline Forced interlocked (d) & $-1.065^{* * *}$ & $-1.100^{* * *}$ & $-1.827^{* * *}$ & $-1.783^{* * *}$ \\
& $(-3.632)$ & $(-3.503)$ & $(-3.631)$ & $(-3.313)$ \\
Director control variables & Yes & Yes & Yes & Yes \\
Turnover FE & Yes & Yes & Yes & Yes \\
Firm FE & No & Yes & No & Yes \\
\hline Observations & 4,013 & 4,013 & 3,300 & 3,300 \\
Firms & 465 & 465 & 404 & 404 \\
Directors & 2,885 & 2,885 & 2,425 & 2,425 \\
Turnover-interlocked directorships & 594 & 594 & 489 & 489 \\
Adjusted $R^{2}$ & 0.025 & 0.027 & 0.106 & 0.108 \\
\hline
\end{tabular}

Panel B: The change in the sum of total assets of all board seats (w/o turnover firm)

\begin{tabular}{|c|c|c|c|c|}
\hline \multirow[t]{3}{*}{ Dependent variable: } & \multicolumn{4}{|c|}{ Difference in the sum of total assets over all directorships (millions) } \\
\hline & $(1)$ & $(2)$ & $(3)$ & $(4)$ \\
\hline & $t_{1}-t_{0}$ & $t_{1}-t_{0}$ & $t_{5}-t_{0}$ & $t_{5}-t_{0}$ \\
\hline \multirow[t]{2}{*}{ Forced interlocked (d) } & -0.055 & -0.067 & 0.623 & 0.660 \\
\hline & $(-0.217)$ & $(-0.249)$ & $(1.275)$ & $(1.267)$ \\
\hline Director control variables & Yes & Yes & Yes & Yes \\
\hline Turnover FE & Yes & Yes & Yes & Yes \\
\hline Firm FE & No & Yes & No & Yes \\
\hline Observations & 4,013 & 4,013 & 3,300 & 3,300 \\
\hline Firms & 465 & 465 & 404 & 404 \\
\hline Directors & 2,885 & 2,885 & 2,425 & 2,425 \\
\hline Turnover-interlocked directorships & 594 & 594 & 489 & 489 \\
\hline Adjusted $R^{2}$ & 0.015 & 0.015 & 0.097 & 0.099 \\
\hline
\end{tabular}




\section{Appendix A. Performance-induced CEO turnover estimation}

We follow Jenter \& Lewellen (2019) and estimate the performance-induced classification for the forced CEO turnovers in our sample using their two-probit estimation Model 2 from Table 4 . The classification follows a two-step approach, which we estimate as follows: In a first step, we estimate two separate probit models on a CEO-firm-year panel for all S\&P 1500 firms between 2003 and 2017. One probit serves to estimate the probability of a performance-induced turnover and one probit serves to estimate the probability of a not performance-induced turnover. Based on these two probit models, we then estimate the implied probabilities of being performance-induced for each turnover. We classify each forced CEO turnover as performance-induced if the implied probability is greater than $50 \%$.

Formally, we first estimate the probability of turnover for each forced CEO turnover using the two independent probit model estimations:

$$
\begin{aligned}
P_{\text {turn }}\left(X_{t}\right) & =P_{\text {other }}+P_{\text {perf-ind }}\left(x_{t}\right)-P_{\text {other }} \cdot P_{\text {perf-ind }}\left(x_{t}\right) \\
& =P_{\text {other }}+\left(1-P_{\text {other }}\right) \cdot P_{\text {perf-ind }}\left(x_{t}\right) \\
& =\Phi_{\text {other }}\left(\alpha_{1}+\alpha_{2} \cdot Z_{1 t}\right)+\left(1-\Phi_{\text {other }}\left(\alpha_{1}+\alpha_{2} \cdot Z_{1 t}\right)\right) \cdot \Phi_{\text {perf-ind }}\left(\beta_{1}+\beta_{2} \cdot Z_{2 t}\right),
\end{aligned}
$$

where $\mathrm{t}$ indexes firm years: $X_{t}$ is the vector performance measures, $Z_{1 t}$ and $Z_{2 t}$ are vectors of controls, and both $\Phi_{\text {perf-ind }}$ and $\Phi_{\text {other }}$ are standard-normal CDFs.

We then calculate the implied probability of being performance-induced using the estimated turnover probabilities:

$$
P_{\text {perf-ind|turnover }}=\frac{P_{\text {perf-ind }}}{P_{\text {turnover }}}
$$

We base our CEO-firm-year panel on all CEOs of S\&P 1500 firms for which we can find CEO tenure data on BoardEx. Based on this panel, we calculate CEO, tenure, and firm characteristics using BoardEx, Compustat, and CRSP (see Table B.2 for a detailed description of the control variables). Conditioning on at least three years of past performance data, we find data for 4,085 individual CEOs at 2,523 distinct companies. We assign a value of one to our turnover outcome variable in the last fiscal year in which a turnover CEO served during the greater part of the year.

Table A.1 shows the regression outcome of the two probit estimations. The coefficients and magnitudes of our estimation are similar to the results by Jenter \& Lewellen (2019), with the difference that our return coefficients are ten times larger. This difference is most likely due to scaling differences in the 
return variables between ours and theirs. Using the estimations in Table A.1 we classify 238 of the forced CEO turnovers as performance-induced, and 28 forced CEO turnovers as not performance-induced. 
Table A.1: Performance-induced turnover using the two-probit model

This table reports the results of a two-probit model estimation of an indicator for CEO turnover in a given year on firm performance measures and controls. The regression is based on Model 2 of Jenter \& Lewellen (2019)'s two-probit model. Column 1 reports the result of a probit model including performance measures, and Column 2 of a probit model without performance measures. The sample consists of 20,471 tenure-year observations for 4,085 CEOs. z-statistics are reported in parentheses. $* * *, * *$, and ${ }^{*}$ denote statistical significance at the $1 \%, 5 \%$, and $10 \%$ level, respectively. See Section Appendix A for a detailed description of the sample selection process. Definitions and data sources of all variables are provided in Table B.2 in the Appendix.

Dependent variable:

Turnover $(\mathrm{d})$

(1)

Performance-induced

Other

Scaled return $\mathrm{t}=0$

$-0.028^{* * *}$

$(-7.837)$

Scaled return $\mathrm{t}=-1$

$-0.021^{* * *}$

$(-5.902)$

Scaled return $\mathrm{t}=-2$

$-0.006^{*}$

$(-1.888)$

Age (yr)

$0.036^{* * *}$

(17.881)

$0.025^{* * *}$

Age 61-63 (d)

Age 64-66 (d)

$0.449^{* * *}$

(8.280)

Age $>66(d)$

$0.148^{* *}$

(2.468)

Tenure (yr)

$-0.009 * * *$

$-0.008^{* * *}$

Dividend payer (d)

Total assets (millions), log

Observations

20,471

20,471

Firms

2,523

2,523

Pseudo $R^{2}$

0.036

0.034 


\section{Appendix B. Variable definitions}

Table B.1: Variable definitions

This table shows the variable definitions and sources of all variables used throughout the paper. Database mnemonics are provided in italic capitals.

Panel A: (Interlocked) Director characteristics

\begin{tabular}{|c|c|c|}
\hline Variable & Definition & Source \\
\hline Age (yrs) & Age & BoardEx/ISS \\
\hline Female (d) & Dummy equal to 1 if the director is female, 0 otherwise & BoardEx/ISS \\
\hline Tenure (yrs) & Time the director has spent as board member & BoardEx/ISS \\
\hline \# of other board seats & Number of other outside board seats held by the director & BoardEx \\
\hline ISS withhold/against (d) & $\begin{array}{l}\text { Dummy equal to } 1 \text { if ISS recommended shareholders to } \\
\text { withhold their votes or vote against the re-election of the } \\
\text { director, } 0 \text { otherwise }\end{array}$ & ISS \\
\hline$\%$ votes withheld & $\begin{array}{l}\text { Fraction of votes against the re-election of the director or } \\
\text { withheld; (votedagainst }+ \text { votedabstain }) /(\text { votedfor }+ \\
\text { votedagainst }+ \text { votedabstain })\end{array}$ & ISS \\
\hline $\begin{array}{l}\text { Time between meeting } \\
\text { dates (yr) }\end{array}$ & $\begin{array}{l}\text { Time between two consecutive director re-election dates } \\
\text { at the same company }\end{array}$ & ISS \\
\hline Co-opted director $(d)$ & $\begin{array}{l}\text { Dummy equal to } 1 \text { if the interlocked director became } \\
\text { director after the departing CEO was appointed, } 0 \\
\text { otherwise }\end{array}$ & BoardEx/ISS \\
\hline $\begin{array}{l}\text { Nominating or } \\
\text { compensation committee } \\
\text { (d) }\end{array}$ & $\begin{array}{l}\text { Dummy equal to } 1 \text { if the interlocked director is member of } \\
\text { the nomination or compensation committee, } 0 \text { otherwise }\end{array}$ & BoardEx/ISS \\
\hline Committee-interlocked (d) & $\begin{array}{l}\text { Dummy equal to } 1 \text { if a director is a member of the same } \\
\text { main committee as a forced turnover interlocked director, } \\
0 \text { otherwise. Main committees are defined as the } \\
\text { nominating, compensation, corporate governance, and } \\
\text { audit committee. }\end{array}$ & BoardEx/ISS \\
\hline
\end{tabular}

Panel B: Firm characteristics

\begin{tabular}{|c|c|c|}
\hline Variable & Definition & Source \\
\hline Total assets (millions) & Total assets; $A T$ & Compustat \\
\hline Leverage & Financial leverage; $(D L C+D L T T) / A T$ & Compustat \\
\hline Tobin's $Q$ & $\begin{array}{l}\text { Tobin's } \mathrm{Q} \text { (market value of assets to book value); } \\
\left(A T+C S H O * P R C C \_F-C E Q-T X D B\right) / A T \text {. Missing } \\
\text { values in } T X D B \text { have been set to } 0 .\end{array}$ & Compustat \\
\hline$R O A$ & $\begin{array}{l}\text { Return on assets; coalesce }(O I B D P, S A L E- \\
X O P R, R E V T-X O P R) /((A T+\operatorname{lag}(A T)) / 2)\end{array}$ & Compustat \\
\hline BH return $(m 270, m 21)$ & $\begin{array}{l}\text { Buy-and-hold-return from } t-270 \text { to } t-21 \text { with } t=0 \\
\text { being the director re-election date; adjusted for equally } \\
\text { weighted market return }\end{array}$ & CRSP \\
\hline $\begin{array}{l}\text { SEP } 1500 \text { index } \\
\text { constituent }(d)\end{array}$ & $\begin{array}{l}\text { Dummy equal to } 1 \text { if the firm is constituent of the } \mathrm{S} \& \mathrm{P} \\
1500 \text { at that moment, } 0 \text { otherwise }\end{array}$ & Compustat \\
\hline Board size & Board size & BoardEx \\
\hline$\%$ outside directors & $\begin{array}{l}\text { The percentage of outside directors in the board, as a } \\
\text { fraction of board size }\end{array}$ & BoardEx \\
\hline$\%$ busy outside directors & $\begin{array}{l}\text { The percentage of outside directors with more than } 2 \\
\text { board memberships, as a fraction of number of outside } \\
\text { directors }\end{array}$ & BoardEx \\
\hline Institutional ownership (\%) & The percentage of shares owned by $13 \mathrm{~F}$ institutions & $\begin{array}{r}\text { Thomson } \\
\text { Reuters }\end{array}$ \\
\hline
\end{tabular}




\section{Table B.1: Variable definitions (cont.)}

Panel C: Forced turnover characteristics

\begin{tabular}{llr}
\hline Variable & Definition & Source \\
\hline $\begin{array}{l}\text { Full replacement } \\
\text { announced }(d)\end{array}$ & $\begin{array}{l}\text { Dummy equal to } 1 \text { if the company announced a full } \\
\text { replacement CEO at the departure announcement, } 0\end{array}$ & BoardEx/Factiva \\
otherwise & $\begin{array}{l}\text { Dummy equal to } 1 \text { if the forced CEO turnover was } \\
\text { performance-induced as estimated using the two-probit } \\
\text { merformance-induced }(d)\end{array}$ & See Table \\
& $\begin{array}{l}\text { Dummy equal to } 1 \text { if the forced out CEO had a tenure of } \\
\text { less than three years, } 0 \text { otherwise }\end{array}$ & BoardEx/ISS \\
Honeymoon stage $(d)$ & $\begin{array}{l}\text { Dummy equal to } 1 \text { if the forced out CEO had a tenure of } \\
\text { between three and } 13 \text { years, 0 otherwise }\end{array}$ & BoardEx/ISS \\
Harvest stage $(d)$ & $\begin{array}{l}\text { Dummy equal to } 1 \text { if the forced out CEO had a tenure of } \\
\text { more than } 13 \text { years, } 0 \text { otherwise }\end{array}$ & BoardEx/ISS \\
Decline stage $(d)$ & &
\end{tabular}

Panel D: Board turnover variables

\begin{tabular}{|c|c|c|}
\hline Variable & Definition & Source \\
\hline $\begin{array}{l}\text { Loses directorships within } t \\
\text { years (d) }\end{array}$ & $\begin{array}{l}\text { Dummy equal to } 1 \text { if the director loses any of her outside } \\
\text { directorships within t years following the interlocked } \\
\text { forced CEO turnover, } 0 \text { otherwise }\end{array}$ & BoardEx \\
\hline $\begin{array}{l}\text { Gains directorships within } \\
t \text { years }(d)\end{array}$ & $\begin{array}{l}\text { Dummy equal to } 1 \text { if the director obtains a new outside } \\
\text { directorships within t years following the interlocked } \\
\text { forced CEO turnover, } 0 \text { otherwise }\end{array}$ & BoardEx \\
\hline $\begin{array}{l}\text { Net loss of directorships } \\
\text { within } t \text { years (d) }\end{array}$ & $\begin{array}{l}\text { Dummy equal to } 1 \text { if the director loses more outside } \\
\text { directorships than she gains new ones within t years } \\
\text { following the interlocked forced CEO turnover, } 0 \text { otherwise }\end{array}$ & BoardEx \\
\hline $\begin{array}{l}\text { Sum of total assets over all } \\
\text { directorships (millions) }\end{array}$ & $\begin{array}{l}\text { Sum of total assets over all directorships a director holds; } \\
A T\end{array}$ & $\begin{array}{l}\text { BoardEx, } \\
\text { Compustat }\end{array}$ \\
\hline $\begin{array}{l}\text { Sum of market } \\
\text { capitalization over all } \\
\text { directorships (millions) }\end{array}$ & $\begin{array}{l}\text { Sum of market capitalization over all directorships a } \\
\text { director holds; } P R C C \_F * C S H O\end{array}$ & $\begin{array}{r}\text { BoardEx, } \\
\text { Compustat }\end{array}$ \\
\hline
\end{tabular}


Table B.2: Variable definitions for performance-induced classification

This table shows the variable definitions and sources of all variables used in the two-probit performanceinduced estimation from Appendix A All definitions are based on Jenter \& Lewellen (2019). Compustat mnemonics are provided in italic capitals.

\begin{tabular}{llr}
\hline Variable & Definition & Source \\
\hline Scaled return & $\begin{array}{l}\text { Average one year industry-adjusted monthly } \\
\text { stock returns, scaled by the standard deviation } \\
\text { of returns over the past } 48 \text { months. } t=0 \text { is } \\
\text { defined as the fiscal year for non-turnover years, } \\
\text { and the } 12 \text { months until the turnover } \\
\text { announcement date for turnover years. }\end{array}$ & $\begin{array}{r}\text { CRSP, Ken French's } \\
\text { Data Library }\end{array}$ \\
& Age & BoardEx \\
Age $(y r)$ & Dummy equal to 1 if the age of the CEO is & BoardEx \\
Age $61-63(d)$ & between 61 and 63,0 otherwise & BoardEx \\
Age 61-63 $(d)$ & Dummy equal to 1 if the age of the CEO is & BoardEx \\
Age 61-63 $(d)$ & Detween 64 and 66,0 otherwise & BoardEx \\
Tenure $(y r)$ & above 66,0 otherwise & Compustat \\
Dividend payer $(d)$ & Time in years the CEO spent in office & Compustat \\
\hline
\end{tabular}


Table B.3: Variable definitions for propensity score matching

This table shows the variable definitions and sources of all variables used in the propensity score estimation from Section 4.2. The definitions are based on Peters \& Wagner (2014). Compustat mnemonics are provided in italic capitals.

\begin{tabular}{|c|c|c|}
\hline Variable & Definition & Source \\
\hline Industry volatility in $t-1$ & $\begin{array}{l}\text { Industry volatility in } t-1 \text { years with } t=0 \\
\text { being the director CEO turnover date, } \\
\text { calculated over } 10 \text { years, using monthly returns }\end{array}$ & $\begin{array}{r}\text { Ken French's Data } \\
\text { Library }\end{array}$ \\
\hline Total assets (millions) & Total assets; $A T$ & Compustat \\
\hline Tobin's $Q$ & $\begin{array}{l}\text { Tobin's } \mathrm{Q} \text { (market value of assets to book } \\
\text { value); } \\
\left(A T+C S H O * P R C C \_F-C E Q-T X D B\right) / A T \text {. } \\
\text { Missing values in } T X D B \text { have been set to } 0 \text {. }\end{array}$ & Compustat \\
\hline Idiosyncratic return (m270,m21) & $\begin{array}{l}\text { Buy-and-hold-return from } t-270 \text { to } t-21 \text { with } \\
t=0 \text { being the director CEO turnover date; } \\
\text { adjusted for equally weighted industry return }\end{array}$ & $\begin{array}{r}\text { CRSP, Ken French's } \\
\text { Data Library }\end{array}$ \\
\hline $\begin{array}{l}\text { Market-adj. industry return } \\
(\text { m270,m21) }\end{array}$ & $\begin{array}{l}\text { Buy-and-hold-return from } t-270 \text { to } t-21 \text { with } \\
t=0 \text { being the director CEO turnover date; } \\
\text { adjusted for equally weighted market return }\end{array}$ & $\begin{array}{r}\text { CRSP, Ken French's } \\
\text { Data Library }\end{array}$ \\
\hline Industry-adj. volatility in $t-1$ & $\begin{array}{l}\text { Volatility in } t-1 \text { years with } t=0 \text { being the } \\
\text { director CEO turnover date, calculated over } 48 \\
\text { months, adjusted for equally weighted industry } \\
\text { returns, using monthly returns }\end{array}$ & $\begin{array}{r}\text { CRSP, Ken French's } \\
\text { Data Library }\end{array}$ \\
\hline Equity-based pay $>0(d)$ & $\begin{array}{l}\text { Dummy equal to } 1 \text { if the CEO received a } \\
\text { positive amount of equity-based pay, } 0 \\
\text { otherwise }\end{array}$ & Execucomp \\
\hline Dollar incentives & $\begin{array}{l}\text { Pay-performance-sensitivity, calculated based } \\
\text { on the SAS code from Daniel et al. }(2020)\end{array}$ & Execucomp \\
\hline$C E O$ age $\geq 60(d)$ & $\begin{array}{l}\text { Dummy equal to } 1 \text { if the CEO is older than } 59 \text {, } \\
0 \text { otherwise }\end{array}$ & BoardEx \\
\hline CEO tenure & Time in years the CEO spent in office & BoardEx/Execucomp \\
\hline$C E O$ is outsider (d) & $\begin{array}{l}\text { Dummy equal to } 1 \text { if the CEO joined the } \\
\text { company less than one year prior to his } \\
\text { appointment as CEO, } 0 \text { otherwise }\end{array}$ & BoardEx/Execucomp \\
\hline CEO is chairman (d) & $\begin{array}{l}\text { Dummy equal to } 1 \text { if the CEO seves as } \\
\text { chairman of the board, } 0 \text { otherwise }\end{array}$ & BoardEx \\
\hline Board size & Board size & BoardEx \\
\hline$\%$ independent directors $>50(d)$ & $\begin{array}{l}\text { Dummy equal to } 1 \text { if a majority of directors is } \\
\text { independent, } 0 \text { otherwise }\end{array}$ & BoardEx \\
\hline GIM index (mod.) & $\begin{array}{l}\text { Modified G-Index based on Peters \& Wagner } \\
(2014)\end{array}$ & ISS \\
\hline $\begin{array}{l}\text { Mean change in withheld votes } \\
(\%)\end{array}$ & $\begin{array}{l}\text { Mean change in withheld votes of all board } \\
\text { member re-election at the most recent annual } \\
\text { meeting }\end{array}$ & ISS \\
\hline
\end{tabular}




\section{Appendix C. Internal validity: Main analysis on a balanced control sample}

Table C.1: Main analysis on a control sample without single-board seat directors

This table reports the results of a difference-in-difference regression of the change in the share of withheld votes in re-election on a treatment indicator related to a forced CEO turnover event at an interlocked board appointment of the director and control variables. It replicates the analysis in Table 3.2 but with a restricted sample in which all control directors that hold no additional board seats are excluded. Column 1 reports the baseline regression. Column 2 reports the baseline regression with added interlocked firm fixed effects (FE), and Column 3 reports the baseline regression with added director fixed effects. The unit of observation is a director-firm-meeting date triplet. All regressions are estimated using ordinary least squares (OLS) in first differences to remove director-firm fixed effects and include year times interlocked firm Fama-French 48 industry fixed effects to remove industry shocks. Withheld votes are calculated as the sum of votes withheld and against a director re-election, divided by the total number of votes cast. The control variables are as in Table 4 The sample is based on the intersection of all forced CEO turnovers covered in ISS and BoardEx between January 2003 and December 2017 and includes a total of 607 interlocked director re-elections involving 443 distinct directors at 467 firms, and 61,619 non-turnover-interlocked director re-elections involving 12,705 distinct directors at 3,136 firms. t-statistics are reported in parentheses and are based on standard errors clustered at the industry level. $* * *, * *$, and $*$ denote statistical significance at the $1 \%, 5 \%$, and $10 \%$ level, respectively. See Section 2 for a detailed description of the sample selection process. Definitions and data sources of all variables are provided in Table B.1 in the Appendix.

\begin{tabular}{lrrr}
\hline Dependent variable: & \multicolumn{3}{c}{ \% votes withheld } \\
\cline { 2 - 4 } & \multicolumn{1}{c}{$(1)$} & \multicolumn{2}{c}{$(2)$} \\
\hline Forced interlocked $(d)$ & $1.116^{* * *}$ & $0.842^{* *}$ & $0.878^{* *}$ \\
& $(2.843)$ & $(2.378)$ & $(2.044)$ \\
Control variables & Yes & Yes & Yes \\
Year $\times$ Industry FE & Yes & Yes & Yes \\
Firm FE & No & Yes & No \\
Director FE & No & No & Yes \\
\hline Observations & 62,226 & 62,226 & 62,226 \\
Firms & 3,136 & 3,136 & 3,136 \\
Directors & 12,705 & 12,705 & 12,705 \\
Turnover-interlocked directorships & 607 & 607 & 607 \\
Adjusted $R^{2}$ & 0.331 & 0.345 & 0.352 \\
\hline
\end{tabular}




\section{Appendix D. Propensity score matching: Estimation, common support, and balance}

Table D.1: Propensity score estimation

This table reports the results of a logistic regression of forced CEO turnover on a set of predictors. The regression model in Columns 1-2 is based on Model 5 of Peters \& Wagner (2014)'s first-stage regression of forced CEO turnovers. In Columns $3-4$, we extend the regression model by an additional variable that measures the mean change in re-election votes of all board members prior to the matching date. Columns 1 and 3 report the log-odds and Column 2 and 4 the odd ratios of the regression models. Tobin's Q, Idiosyncratic return, Market-adjusted industry return, and Dollar incentives are winsorized at the 1st and 99th percentiles. The sample in Columns 1-2 consists of 183 distinct turnover events and includes 183 observations of turnover firms and 160,311 observations of potential control firms. The sample in Columns 3-4 consists of 149 distinct turnover events and includes 149 observations of turnover firms and 115,760 observations of potential control firms. Turnover firms are defined as S\&P 1500 index firms that forced out their CEO at the respective turnover date. Control firms are defined as S\&P 1500 index firms that do not experience a forced CEO turnover within five years before or after the respective turnover date, and for which we identify outside directors with additional interlocked directorships and vote share data at the interlocked firms. z-statistics are reported in parentheses. $* * *, * *$, and $*$ denote statistical significance at the $1 \%, 5 \%$, and $10 \%$ level, respectively. See Section 4.2 for a detailed description of the sample selection process. Definitions and data sources of all variables are provided in Table B.3 in the Appendix.

\begin{tabular}{|c|c|c|c|c|}
\hline \multirow[t]{2}{*}{ Dependent variable: } & \multicolumn{4}{|c|}{ Forced turnover $(\mathrm{d})$} \\
\hline & $\begin{array}{c}(1) \\
\text { Log-odds }\end{array}$ & $\begin{array}{c}(2) \\
\text { Odd ratios }\end{array}$ & $\begin{array}{c}(3) \\
\text { Log-odds }\end{array}$ & $\begin{array}{c}(4) \\
\text { Odd ratios }\end{array}$ \\
\hline Industry volatility in $\mathrm{t}-1$ & $\begin{array}{r}2.304 \\
(0.663)\end{array}$ & $\begin{array}{r}10.012 \\
(0.663)\end{array}$ & $\begin{array}{r}0.736 \\
(0.184)\end{array}$ & $\begin{array}{r}2.087 \\
(0.184)\end{array}$ \\
\hline Total assets (millions), log & $\begin{array}{r}0.074 \\
(0.998)\end{array}$ & $\begin{array}{r}1.076 \\
(0.998)\end{array}$ & $\begin{array}{r}0.065 \\
(0.867)\end{array}$ & $\begin{array}{r}1.068 \\
(0.867)\end{array}$ \\
\hline Tobin's Q & $\begin{array}{r}-0.106 \\
(-1.029)\end{array}$ & $\begin{array}{r}0.900 \\
(-1.029)\end{array}$ & $\begin{array}{r}-0.111 \\
(-0.973)\end{array}$ & $\begin{array}{r}0.895 \\
(-0.973)\end{array}$ \\
\hline Idiosyncratic return $(\mathrm{m} 270, \mathrm{~m} 21)$ & $\begin{array}{r}-3.004^{* * *} \\
(-9.196)\end{array}$ & $\begin{array}{r}0.050^{* * *} \\
(-9.196)\end{array}$ & $\begin{array}{r}-3.116^{* * *} \\
(-8.686)\end{array}$ & $\begin{array}{r}0.044^{* * *} \\
(-8.686)\end{array}$ \\
\hline Market-adj. industry return $(\mathrm{m} 270, \mathrm{~m} 21)$ & $\begin{array}{r}-1.717^{* * *} \\
(-4.023)\end{array}$ & $\begin{array}{r}0.180^{* * *} \\
(-4.023)\end{array}$ & $\begin{array}{r}-1.872^{* * *} \\
(-3.749)\end{array}$ & $\begin{array}{r}0.154^{* * *} \\
(-3.749)\end{array}$ \\
\hline Industry-adj. volatility in t-1 & $\begin{array}{r}1.265 \\
(0.741)\end{array}$ & $\begin{array}{r}3.544 \\
(0.741)\end{array}$ & $\begin{array}{r}2.635 \\
(1.383)\end{array}$ & $\begin{array}{r}13.945 \\
(1.383)\end{array}$ \\
\hline Equity-based pay $>0(\mathrm{~d})$ & $\begin{array}{r}0.111 \\
(0.397)\end{array}$ & $\begin{array}{r}1.118 \\
(0.397)\end{array}$ & $\begin{array}{r}-0.137 \\
(-0.463)\end{array}$ & $\begin{array}{r}0.872 \\
(-0.463)\end{array}$ \\
\hline Dollar incentives, log & $\begin{array}{r}-0.084 \\
(-1.237)\end{array}$ & $\begin{array}{r}0.919 \\
(-1.237)\end{array}$ & $\begin{array}{r}-0.099 \\
(-1.321)\end{array}$ & $\begin{array}{r}0.906 \\
(-1.321)\end{array}$ \\
\hline CEO age $\geq 60(d)$ & $\begin{array}{r}-0.974^{* * *} \\
(-3.571)\end{array}$ & $\begin{array}{r}0.378^{* * *} \\
(-3.571)\end{array}$ & $\begin{array}{r}-0.882^{* * *} \\
(-3.022)\end{array}$ & $\begin{array}{r}0.414^{* * *} \\
(-3.022)\end{array}$ \\
\hline CEO tenure & $\begin{array}{r}-0.056^{* * *} \\
(-3.193)\end{array}$ & $\begin{array}{r}0.945^{* * *} \\
(-3.193)\end{array}$ & $\begin{array}{r}-0.067^{* * * *} \\
(-3.434)\end{array}$ & $\begin{array}{r}0.935^{* * *} \\
(-3.434)\end{array}$ \\
\hline CEO is outsider $(d)$ & $\begin{array}{r}0.689^{* * *} \\
(4.325)\end{array}$ & $\begin{array}{r}1.992^{* * *} \\
(4.325)\end{array}$ & $\begin{array}{r}0.761^{* * *} \\
(4.223)\end{array}$ & $\begin{array}{r}2.140^{* * *} \\
(4.223)\end{array}$ \\
\hline CEO is chairman (d) & $\begin{array}{r}-0.705^{* * *} \\
(-3.382)\end{array}$ & $\begin{array}{r}0.494^{* * *} \\
(-3.382)\end{array}$ & $\begin{array}{r}-0.741^{* * *} \\
(-3.085)\end{array}$ & $\begin{array}{r}0.476^{* * *} \\
(-3.085)\end{array}$ \\
\hline Board size, log & $\begin{array}{r}-1.117^{* *} \\
(-2.450)\end{array}$ & $\begin{array}{l}0.327^{* *} \\
(-2.450)\end{array}$ & $\begin{array}{r}-1.328^{* *} \\
(-2.520)\end{array}$ & $\begin{array}{l}0.265^{* *} \\
(-2.520)\end{array}$ \\
\hline$\%$ independent directors $>50(\mathrm{~d})$ & $\begin{array}{r}-0.325 \\
(-1.032)\end{array}$ & $\begin{array}{r}0.723 \\
(-1.032)\end{array}$ & $\begin{array}{r}-0.169 \\
(-0.412)\end{array}$ & $\begin{array}{r}0.844 \\
(-0.412)\end{array}$ \\
\hline GIM index (mod.) & $\begin{array}{r}-0.026 \\
(-0.546)\end{array}$ & $\begin{array}{r}0.974 \\
(-0.546)\end{array}$ & $\begin{array}{r}-0.022 \\
(-0.385)\end{array}$ & $\begin{array}{r}0.978 \\
(-0.385)\end{array}$ \\
\hline Mean change in withheld votes (\%) & & & $\begin{array}{r}0.022^{* *} \\
(2.361)\end{array}$ & $\begin{array}{r}1.022^{* *} \\
(2.361)\end{array}$ \\
\hline Year FE & Yes & Yes & Yes & Yes \\
\hline Observations & 160,494 & 160,494 & 115,909 & 115,909 \\
\hline Firms & 1,888 & 1,888 & 1,710 & 1,710 \\
\hline Pseudo $R^{2}$ & 0.098 & 0.098 & 0.119 & 0.119 \\
\hline
\end{tabular}


Table D.2: Covariate balance test, pre-matching

This table reports a covariate balance test between the forced CEO turnover firms sample ("turnover firms") and the potential control firms ("control firms"). It compares the number of observations, means, and differences of all variables used in the propensity score estimation. Tobin's Q, Idiosyncratic return, Market-adjusted industry return, and Dollar incentives are winsorized at the 1st and 99th percentiles. The sample consists of 183 distinct turnover events and includes 183 turnover firm observations and 160,311 observations of potential control firms. Turnover firms are defined as S\&P 1500 index firms that forced out their $\mathrm{CEO}$ at the respective turnover date. Control firms are defined as $\mathrm{S} \& \mathrm{P} 1500$ index firms that do not experience a forced CEO turnover within five years before or after the respective turnover date, and for which we identify outside directors with additional interlocked directorships and vote share data at the interlocked firms. $* * *$, $* *$, and $*$ denote statistical significance at the $1 \%, 5 \%$, and $10 \%$ level, respectively. Definitions and data sources of all variables are provided in Table B.3 in the Appendix.

\begin{tabular}{|c|c|c|c|c|c|c|}
\hline & \multicolumn{2}{|c|}{ Turnover firms } & \multicolumn{2}{|c|}{ Control firms } & \multicolumn{2}{|c|}{ Difference } \\
\hline & $\mathrm{N}$ & Mean & $\mathrm{N}$ & Mean & Diff. & t-test \\
\hline Industry volatility in t-1 & 183 & 0.08 & 160,311 & 0.07 & $0.00^{* * *}$ & 2.80 \\
\hline Total assets (millions), log & 183 & 7.89 & 160,311 & 8.32 & $-0.43^{* * *}$ & -3.46 \\
\hline Tobin's Q & 183 & 1.64 & 160,311 & 1.82 & $-0.18^{* *}$ & -2.43 \\
\hline Idiosyncratic return $(\mathrm{m} 270, \mathrm{~m} 21)$ & 183 & -0.28 & 160,311 & -0.04 & $-0.24^{* * *}$ & -10.69 \\
\hline Market-adj. industry return $(\mathrm{m} 270, \mathrm{~m} 21)$ & 183 & 0.02 & 160,311 & 0.02 & -0.00 & -0.34 \\
\hline Industry-adj. volatility in t-1 & 183 & 0.06 & 160,311 & 0.04 & $0.01^{* * *}$ & 4.00 \\
\hline Equity-based pay $>0(\mathrm{~d})$ & 183 & 0.91 & 160,311 & 0.91 & -0.00 & -0.22 \\
\hline Dollar incentives, log & 183 & 4.75 & 160,311 & 5.55 & $-0.80^{* * *}$ & -7.51 \\
\hline $\mathrm{CEO}$ age $\geq 60(\mathrm{~d})$ & 183 & 0.09 & 160,311 & 0.30 & $-0.21^{* * *}$ & -6.13 \\
\hline CEO tenure & 183 & 4.88 & 160,311 & 7.60 & $-2.72^{* * *}$ & -5.64 \\
\hline CEO is outsider $(\mathrm{d})$ & 183 & 0.44 & 160,311 & 0.29 & $0.15^{* * *}$ & 4.47 \\
\hline CEO is chairman (d) & 183 & 0.27 & 160,311 & 0.55 & $-0.28^{* * *}$ & -7.49 \\
\hline Board size, log & 183 & 2.18 & 160,311 & 2.26 & $-0.08^{* * *}$ & -4.38 \\
\hline$\%$ independent directors $>50(\mathrm{~d})$ & 183 & 0.93 & 160,311 & 0.96 & -0.02 & -1.38 \\
\hline GIM index (mod.) & 183 & 5.30 & 160,311 & 5.50 & -0.21 & -1.59 \\
\hline
\end{tabular}


Table D.3: Covariate balance test, post-matching

This table reports a covariate balance test between the forced CEO turnover firms sample ("turnover firms") and the matched control firms ("control firms"). It compares the number of observations, means, and differences of all variables used in the propensity score estimation. Tobin's Q, Idiosyncratic return, Market-adjusted industry return, and Dollar incentives are winsorized at the 1st and 99th percentiles. The sample consists of 181 distinct turnover events and includes 181 turnover firm observations and 181 matched control firms observations. Turnover firms are defined as S\&P 1500 index firms that forced out their CEO at the respective turnover date. Control firms are defined as S\&P 1500 index firms that do not experience a forced CEO turnover within five years before or after the respective turnover date, and for which we identify outside directors with additional interlocked directorships and vote share data at the interlocked firms. The firms are matched using a one nearest-neighbor propensity score matching algorithm with a maximum caliper width of 0.2 times the pooled standard deviation of the logarithm of the propensity scores. The propensity scores are estimated using Model 5 of Peters \& Wagner (2014)'s first-stage regression of forced CEO turnovers. ***, **, and * denote statistical significance at the $1 \%, 5 \%$, and $10 \%$ level, respectively. Definitions and data sources of all variables are provided in Table B.3 in the Appendix.

\begin{tabular}{|c|c|c|c|c|c|c|}
\hline & \multicolumn{2}{|c|}{ Turnover firms } & \multicolumn{2}{|c|}{ Control firms } & \multicolumn{2}{|c|}{ Difference } \\
\hline & $\mathrm{N}$ & Mean & $\mathrm{N}$ & Mean & Diff. & t-test \\
\hline Industry volatility in t-1 & 181 & 0.08 & 181 & 0.08 & 0.00 & 0.10 \\
\hline Total assets (millions), log & 181 & 7.91 & 181 & 8.04 & -0.13 & -0.73 \\
\hline Tobin's Q & 181 & 1.65 & 181 & 1.67 & -0.03 & -0.30 \\
\hline Idiosyncratic return (m270,m21) & 181 & -0.28 & 181 & -0.27 & -0.01 & -0.30 \\
\hline Market-adj. industry return $(\mathrm{m} 270, \mathrm{~m} 21)$ & 181 & 0.02 & 181 & 0.01 & 0.01 & 0.59 \\
\hline Industry-adj. volatility in $\mathrm{t}-1$ & 181 & 0.06 & 181 & 0.05 & 0.00 & 0.95 \\
\hline Equity-based pay $>0(\mathrm{~d})$ & 181 & 0.91 & 181 & 0.90 & 0.01 & 0.18 \\
\hline Dollar incentives, log & 181 & 4.78 & 181 & 4.76 & 0.03 & 0.19 \\
\hline CEO age $\geq 60(\mathrm{~d})$ & 181 & 0.09 & 181 & 0.08 & 0.02 & 0.56 \\
\hline CEO tenure & 181 & 4.89 & 181 & 4.79 & 0.10 & 0.23 \\
\hline CEO is outsider $(\mathrm{d})$ & 181 & 0.43 & 181 & 0.40 & 0.03 & 0.53 \\
\hline CEO is chairman $(\mathrm{d})$ & 181 & 0.28 & 181 & 0.25 & 0.02 & 0.48 \\
\hline Board size, log & 181 & 2.19 & 181 & 2.20 & -0.01 & -0.43 \\
\hline$\%$ independent directors $>50(\mathrm{~d})$ & 181 & 0.93 & 181 & 0.96 & -0.02 & -0.92 \\
\hline GIM index (mod.) & 181 & 5.29 & 181 & 5.04 & 0.25 & 1.34 \\
\hline
\end{tabular}




\section{Figure D.1: Common support}

These figures plot the density distribution of the propensity scores of the forced CEO turnover firm sample ("turnover firms") and the matched control firms ("control firms"). Figure A presents the density distribution pre-matching, and Figure B the density distribution after applying a one-to-one nearest-neighbor matching algorithm with a maximum caliper width of 0.2 times the pooled standard deviation of the logarithm of the propensity scores. The sample in Figure A consists of 183 distinct turnover events and includes 183 turnover firm observations and 160,311 observations of potential control firms, and the sample in Figure B of 181 distinct turnover events and includes 181 turnover firm observations and 181 matched control firm observations. Turnover firms are defined as S\&P 1500 index firms that forced out their CEO at the respective turnover date. Control firms are defined as S\&P 1500 index firms that do not experience a forced CEO turnover within five years before or after the respective turnover date, and for which we identify outside directors with additional interlocked directorships and vote share data at the interlocked firms. The propensity scores are estimated using Model 5 of Peters \& Wagner (2014)'s first-stage regression of forced CEO turnovers. Figure A depicts only propensity scores of the control sample that are within the range of propensity scores of the turnover sample. Observations with a higher propensity than the maximum propensity of the turnover sample are dropped from the Figure.

Figure A: Propensity score distribution, pre-matching

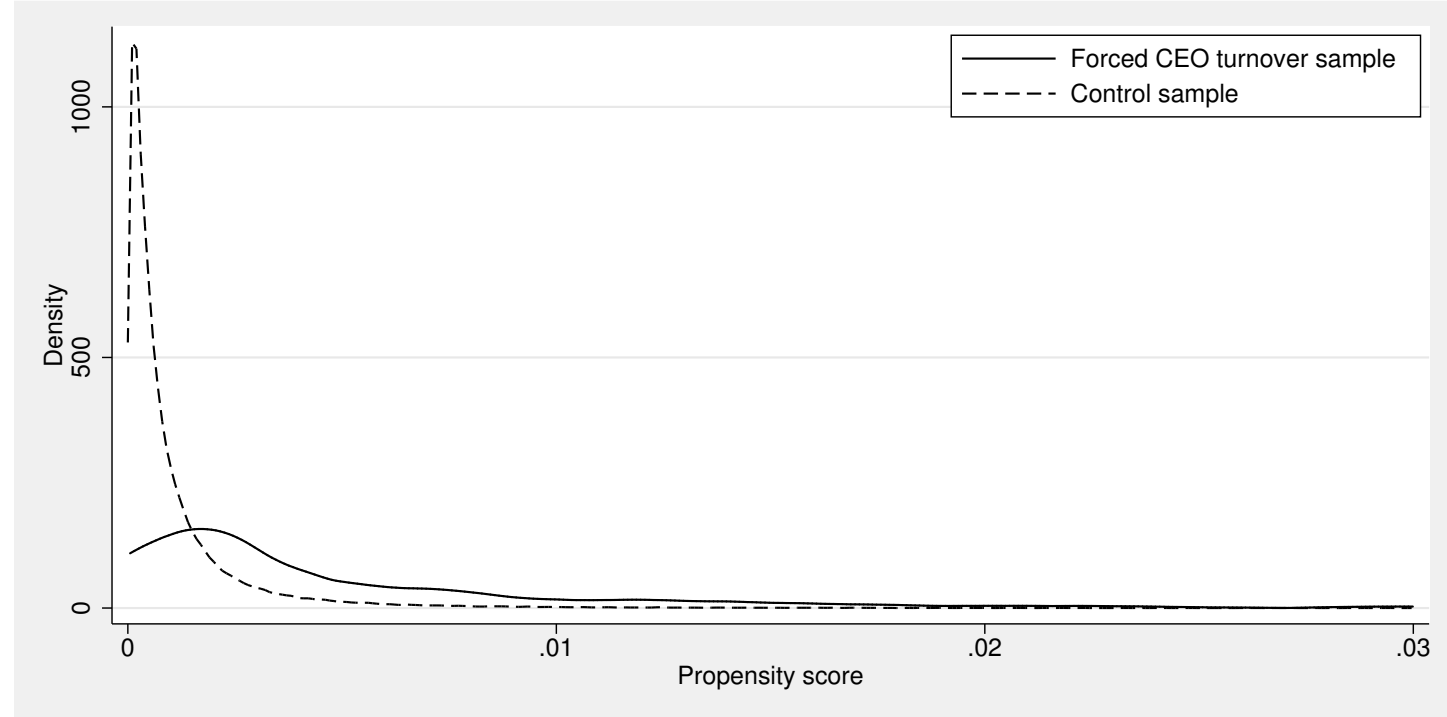

Figure B: Propensity score distribution, post-matching

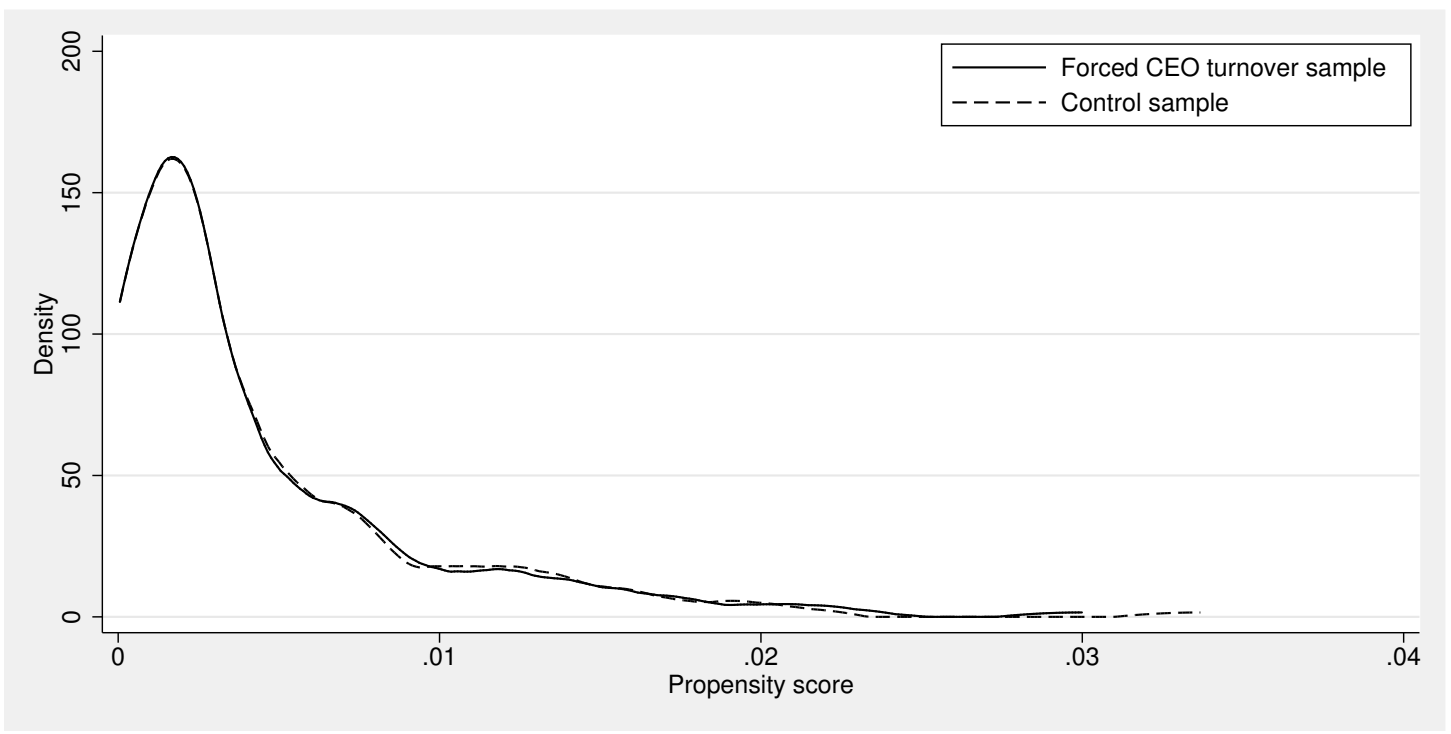


Table D.4: Covariate balance test for extended model, pre-matching

This table reports a covariate balance test between the forced CEO turnover firms sample ("turnover firms") and the potential control firms ("control firms"). It compares the number of observations, means, and differences of all variables used in the propensity score estimation. Tobin's Q, Idiosyncratic return, Market-adjusted industry return, and Dollar incentives are winsorized at the 1st and 99th percentiles. The sample consists of 149 distinct turnover events and includes 149 turnover firm observations and 115,760 observations of potential control firms. Turnover firms are defined as S\&P 1500 index firms that forced out their $\mathrm{CEO}$ at the respective turnover date. Control firms are defined as $\mathrm{S} \& \mathrm{P} 1500$ index firms that do not experience a forced CEO turnover within five years before or after the respective turnover date, and for which we identify outside directors with additional interlocked directorships and vote share data at the interlocked firms. $* * *$, $* *$, and $*$ denote statistical significance at the $1 \%, 5 \%$, and $10 \%$ level, respectively. Definitions and data sources of all variables are provided in Table B.3 in the Appendix.

\begin{tabular}{|c|c|c|c|c|c|c|}
\hline & \multicolumn{2}{|c|}{ Turnover firms } & \multicolumn{2}{|c|}{ Control firms } & \multicolumn{2}{|c|}{ Difference } \\
\hline & $\mathrm{N}$ & Mean & $\mathrm{N}$ & Mean & Diff. & t-test \\
\hline Industry volatility in t-1 & 149 & 0.07 & 115,760 & 0.07 & $0.00^{* *}$ & 2.32 \\
\hline Total assets (millions), log & 149 & 7.90 & 115,760 & 8.42 & $-0.52^{* * *}$ & -3.71 \\
\hline Tobin's Q & 149 & 1.63 & 115,760 & 1.82 & $-0.19^{* *}$ & -2.29 \\
\hline Idiosyncratic return $(\mathrm{m} 270, \mathrm{~m} 21)$ & 149 & -0.27 & 115,760 & -0.02 & $-0.25^{* * *}$ & -10.14 \\
\hline Market-adj. industry return $(\mathrm{m} 270, \mathrm{~m} 21)$ & 149 & 0.01 & 115,760 & 0.02 & -0.01 & -0.73 \\
\hline Industry-adj. volatility in $\mathrm{t}-1$ & 149 & 0.06 & 115,760 & 0.04 & $0.02^{* * *}$ & 5.02 \\
\hline Equity-based pay $>0(\mathrm{~d})$ & 149 & 0.89 & 115,760 & 0.92 & -0.03 & -1.43 \\
\hline Dollar incentives, log & 149 & 4.69 & 115,760 & 5.53 & $-0.84^{* * *}$ & -7.23 \\
\hline $\mathrm{CEO}$ age $\geq 60(\mathrm{~d})$ & 149 & 0.10 & 115,760 & 0.31 & $-0.21^{* * *}$ & -5.54 \\
\hline CEO tenure & 149 & 4.92 & 115,760 & 7.74 & $-2.82^{* * *}$ & -5.33 \\
\hline CEO is outsider $(\mathrm{d})$ & 149 & 0.46 & 115,760 & 0.28 & $0.18^{* * *}$ & 4.88 \\
\hline CEO is chairman (d) & 149 & 0.25 & 115,760 & 0.53 & $-0.28^{* * *}$ & -6.90 \\
\hline Board size, log & 149 & 2.17 & 115,760 & 2.26 & $-0.09 * * *$ & -4.87 \\
\hline$\%$ independent directors $>50(\mathrm{~d})$ & 149 & 0.95 & 115,760 & 0.97 & -0.01 & -0.84 \\
\hline GIM index (mod.) & 149 & 5.33 & 115,760 & 5.59 & $-0.26^{*}$ & -1.85 \\
\hline Mean change in withheld votes (\%) & 149 & 2.86 & 115,760 & 0.84 & $2.03^{* * *}$ & 3.14 \\
\hline
\end{tabular}


Table D.5: Covariate balance test for extended model, post-matching

This table reports a covariate balance test between the forced CEO turnover firms sample ("turnover firms") and the matched control firms ("control firms"). It compares the number of observations, means, and differences of all variables used in the propensity score estimation. Tobin's Q, Idiosyncratic return, Market-adjusted industry return, and Dollar incentives are winsorized at the 1st and 99th percentiles. The sample consists of 147 distinct turnover events and includes 147 turnover firm observations and 147 matched control firms observations. Turnover firms are defined as S\&P 1500 index firms that forced out their CEO at the respective turnover date. Control firms are defined as S\&P 1500 index firms that do not experience a forced CEO turnover within five years before or after the respective turnover date, and for which we identify outside directors with additional interlocked directorships and vote share data at the interlocked firms. The firms are matched using a one nearest-neighbor propensity score matching algorithm with a maximum caliper width of 0.2 times the pooled standard deviation of the logarithm of the propensity scores. The propensity scores are estimated using Model 5 of Peters \& Wagner (2014)'s first-stage regression of forced CEO turnovers, extended by an additional variable that measures the mean change in re-election votes of all board members prior to the matching date. ${ }^{* * *},{ }^{* *}$, and ${ }^{*}$ denote statistical significance at the $1 \%, 5 \%$, and $10 \%$ level, respectively. Definitions and data sources of all variables are provided in Table B.3 in the Appendix.

\begin{tabular}{|c|c|c|c|c|c|c|}
\hline & \multicolumn{2}{|c|}{ Turnover firms } & \multicolumn{2}{|c|}{ Control firms } & \multicolumn{2}{|c|}{ Difference } \\
\hline & $\mathrm{N}$ & Mean & $\mathrm{N}$ & Mean & Diff. & t-test \\
\hline Industry volatility in t-1 & 147 & 0.07 & 147 & 0.08 & -0.00 & -0.92 \\
\hline Total assets (millions), log & 147 & 7.93 & 147 & 7.69 & 0.24 & 1.25 \\
\hline Tobin's Q & 147 & 1.63 & 147 & 1.69 & -0.06 & -0.59 \\
\hline Idiosyncratic return $(\mathrm{m} 270, \mathrm{~m} 21)$ & 147 & -0.27 & 147 & -0.26 & -0.01 & -0.23 \\
\hline Market-adj. industry return $(\mathrm{m} 270, \mathrm{~m} 21)$ & 147 & 0.01 & 147 & 0.02 & -0.00 & -0.15 \\
\hline Industry-adj. volatility in t-1 & 147 & 0.06 & 147 & 0.06 & -0.00 & -0.07 \\
\hline Equity-based pay $>0(\mathrm{~d})$ & 147 & 0.89 & 147 & 0.90 & -0.01 & -0.38 \\
\hline Dollar incentives, log & 147 & 4.71 & 147 & 4.74 & -0.02 & -0.16 \\
\hline CEO age $\geq 60(\mathrm{~d})$ & 147 & 0.10 & 147 & 0.08 & 0.02 & 0.60 \\
\hline CEO tenure & 147 & 4.90 & 147 & 4.63 & 0.27 & 0.64 \\
\hline CEO is outsider $(\mathrm{d})$ & 147 & 0.45 & 147 & 0.46 & -0.01 & -0.12 \\
\hline CEO is chairman $(\mathrm{d})$ & 147 & 0.25 & 147 & 0.26 & -0.01 & -0.13 \\
\hline Board size, log & 147 & 2.18 & 147 & 2.16 & 0.02 & 0.70 \\
\hline$\%$ independent directors $>50(\mathrm{~d})$ & 147 & 0.95 & 147 & 0.97 & -0.02 & -0.92 \\
\hline GIM index (mod.) & 147 & 5.32 & 147 & 5.45 & -0.13 & -0.61 \\
\hline Mean change in withheld votes (\%) & 147 & 2.71 & 147 & 2.47 & 0.24 & 0.26 \\
\hline
\end{tabular}


Figure D.2: Common support for extended model

These figures plot the density distribution of the propensity scores of the forced CEO turnover firm sample ("turnover firms") and the matched control firms ("control firms"). Figure A presents the density distribution pre-matching, and Figure B the density distribution after applying a one-to-one nearest-neighbor matching algorithm with a maximum caliper width of 0.2 times the pooled standard deviation of the logarithm of the propensity scores. The sample in Figure A consists of 149 distinct turnover events and includes 149 turnover firm observations and 115,760 observations of potential control firms, and the sample in Figure B of 147 distinct turnover events and includes 147 turnover firm observations and 147 matched control firm observations. Turnover firms are defined as S\&P 1500 index firms that forced out their CEO at the respective turnover date. Control firms are defined as S\&P 1500 index firms that do not experience a forced CEO turnover within five years before or after the respective turnover date, and for which we identify outside directors with additional interlocked directorships and vote share data at the interlocked firms. The propensity scores are estimated using Model 5 of Peters \& Wagner (2014)'s first-stage regression of forced CEO turnovers, extended by an additional variable that measures the mean change in re-election votes of all board members prior to the matching date. Figure A depicts only propensity scores of the control sample that are within the range of propensity scores of the turnover sample. Observations with a higher propensity than the maximum propensity of the turnover sample are dropped from the Figure.

Figure A: Propensity score distribution, pre-matching

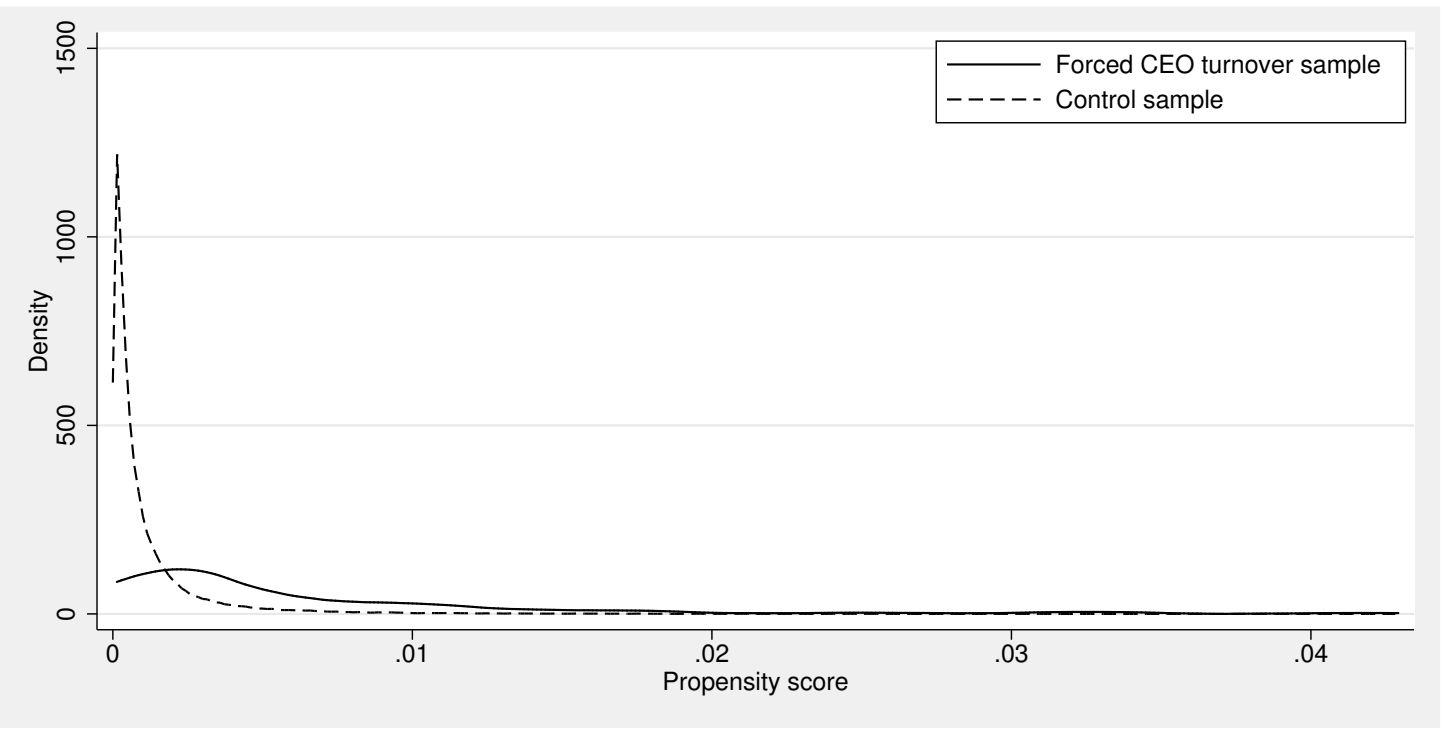

Figure B: Propensity score distribution, post-matching

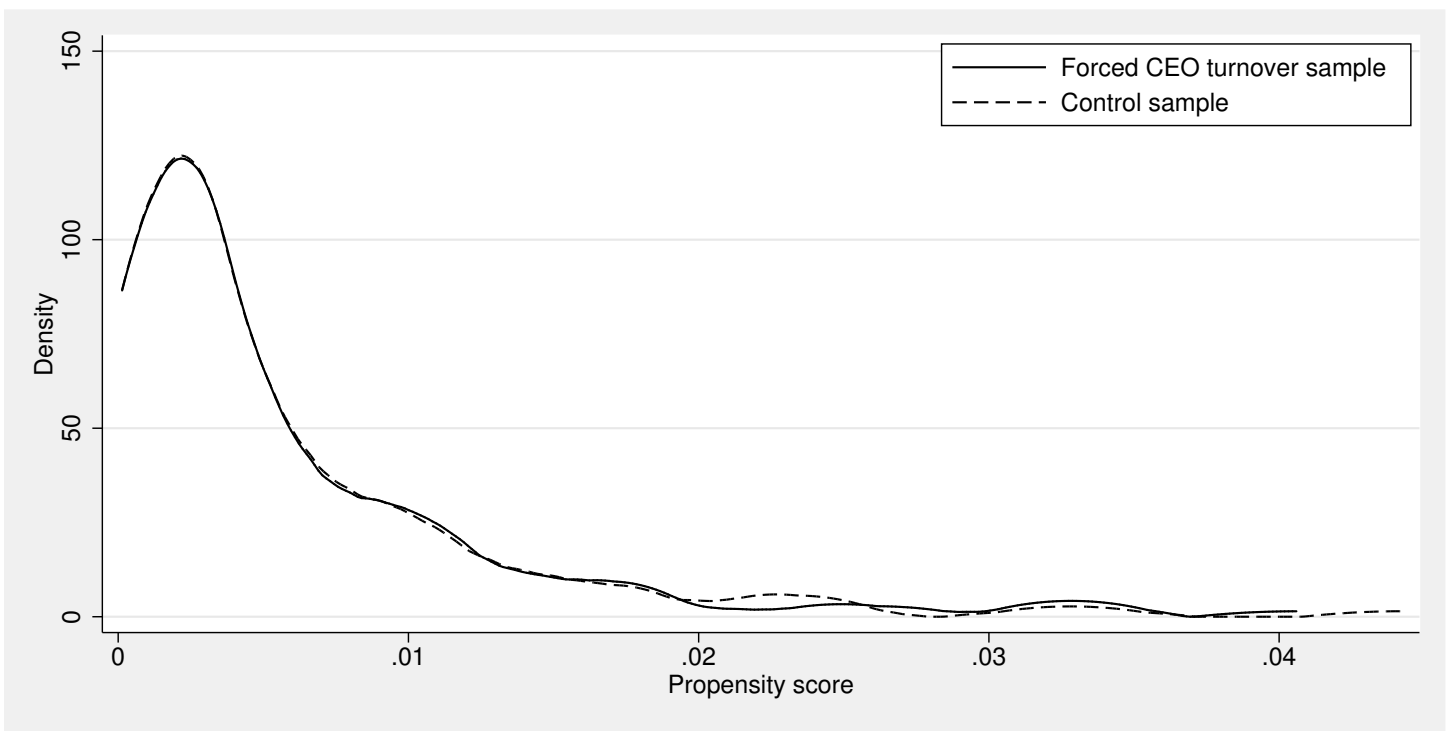




\section{Appendix E. Further analyses on the effect of forced CEO turnover on directors' board}

seats

Table E.1: The effect of forced CEO turnover on the cumulative market capitalization of all board seats

This table reports the results of linear regression models analyzing the effect of a forced CEO turnover on the change of the mean asset size of a director's board seats. The sample consists of 594 (Columns 1 and 2) and 489 (Columns 3 and 4) outside directorships of directors who are interlocked to forced CEO turnovers at S\&P 1500 firms between January 2003 and December 2017 (Forced interlocked $(d)==1$ ), and 3,419 resp. 2,811 outside directorships of directors who are not interlocked to a forced turnover themselves but share a board seat with an interlocked director at the interlocked firm during the time of the interlocked forced turnover (Forced interlocked $(d)==0$ ). The outcome variable in Panel A (Difference in the sum of market cap. over all directorships (millions)) is the hyperbolic sine transformed difference between the sum of market capitalization of all firms at which a director holds an outside directorship at year t following the interlocked forced CEO turnover, and the sum of market capitalization of all firms at which a director holds an outside directorship at the year of the interlocked turnover. The outcome variable in Panel B (Difference in the sum of market cap. over all directorships (millions)) is measured identically to the outcome in Panel A except that it excludes the total assets of the turnover firm. In Columns 1 and 2 of both panels, year $\mathrm{t}$ is defined as one year following the interlocked forced CEO turnover, in Columns 3 and 4 as five years. All Columns include control variables controlling for director age, gender, the number of other outside board seats at the turnover date, and the natural logarithm of tenure at the interlocked firm. Additionally, all Columns include turnover event fixed effects (FE) to remove unobservables from the individual turnover events. Columns 2 and 4 additionally include interlocked firm fixed effects to control for interlocked-firm specific characteristics. All regressions are estimated using ordinary least squares (OLS). t-statistics are reported in parentheses and are based on standard errors clustered at the turnover-event level. ***, **, and * denote statistical significance at the $1 \%, 5 \%$, and $10 \%$ level, respectively. Definitions and data sources of all variables are provided in Table B.1 in the Appendix.

Panel A: The change in the sum of market capitalization of all board seats

\begin{tabular}{|c|c|c|c|c|}
\hline \multirow[t]{2}{*}{ Dependent variable: } & \multicolumn{4}{|c|}{ Difference in the sum of market cap. over all directorships (millions) } \\
\hline & $\begin{array}{c}(1) \\
t_{1}-t_{0}\end{array}$ & $\begin{array}{c}(2) \\
t_{1}-t_{0}\end{array}$ & $\begin{array}{c}(3) \\
t_{5}-t_{0}\end{array}$ & $\begin{array}{c}(4) \\
t_{5}-t_{0}\end{array}$ \\
\hline Forced interlocked (d) & $\begin{array}{r}-1.163^{* * *} \\
(-4.210)\end{array}$ & $\begin{array}{r}-1.186^{* * *} \\
(-4.044)\end{array}$ & $\begin{array}{r}-1.808 * * * \\
(-4.214)\end{array}$ & $\begin{array}{r}-1.817^{* * *} \\
(-4.029)\end{array}$ \\
\hline Director control variables & Yes & Yes & Yes & Yes \\
\hline Turnover FE & Yes & Yes & Yes & Yes \\
\hline Firm FE & No & Yes & No & Yes \\
\hline Observations & 4,013 & 4,013 & 3,300 & 3,300 \\
\hline Firms & 465 & 465 & 404 & 404 \\
\hline Directors & 2,885 & 2,885 & 2,425 & 2,425 \\
\hline Turnover-interlocked directorships & 594 & 594 & 489 & 489 \\
\hline Adjusted $R^{2}$ & 0.032 & 0.036 & 0.127 & 0.131 \\
\hline
\end{tabular}

Panel B: The change in the sum of market capitalization of all board seats (w/o turnover firm)

\begin{tabular}{|c|c|c|c|c|}
\hline \multirow[t]{2}{*}{ Dependent variable: } & \multicolumn{4}{|c|}{ Difference in the sum of market cap. over all directorships (millions) } \\
\hline & $\begin{array}{c}(1) \\
t_{1}-t_{0}\end{array}$ & $\begin{array}{c}(2) \\
t_{1}-t_{0}\end{array}$ & $\begin{array}{c}(3) \\
t_{5}-t_{0}\end{array}$ & $\begin{array}{c}(4) \\
t_{5}-t_{0}\end{array}$ \\
\hline Forced interlocked (d) & $\begin{array}{r}-0.169 \\
(-0.712)\end{array}$ & $\begin{array}{r}-0.167 \\
(-0.675)\end{array}$ & $\begin{array}{r}0.472 \\
(1.037)\end{array}$ & $\begin{array}{r}0.474 \\
(0.985)\end{array}$ \\
\hline Director control variables & Yes & Yes & Yes & Yes \\
\hline Turnover FE & Yes & Yes & Yes & Yes \\
\hline Firm FE & No & Yes & No & Yes \\
\hline Observations & 4,013 & 4,013 & 3,300 & 3,300 \\
\hline Firms & 465 & 465 & 404 & 404 \\
\hline Directors & 2,885 & 2,885 & 2,425 & 2,425 \\
\hline Turnover-interlocked directorships & 594 & 594 & 489 & 489 \\
\hline Adjusted $R^{2}$ & 0.018 & 0.020 & 0.113 & 0.116 \\
\hline
\end{tabular}

